\begin{abstract}
UNIVERSIDADE DE SÃO PAULO
INSTITUTO DE RELAÇÕES INTERNACIONAIS

PROGRAMA DE PÓS-GRADUAÇÃO EM RELAÇÕES INTERNACIONAIS
\end{abstract}

BIANCA TONELLI

DIVERGÊNCIAS NAS POLÍTICAS DE COMÉRCIO INTERNACIONAL NA AMÉRICA DO SUL: TENDÊNCIAS E DESAFIOS NOS ACORDOS PREFERENCIAIS DE COMÉRCIO - PTAS 
UNIVERSIDADE DE SÃO PAULO

INSTITUTO DE RELAÇÕES INTERNACIONAIS

PROGRAMA DE PÓS-GRADUAÇÃO EM RELAÇÕES INTERNACIONAIS

\section{DIVERGÊNCIAS NAS POLÍTICAS DE COMÉRCIO INTERNACIONAL NA AMÉRICA DO SUL: TENDÊNCIAS E DESAFIOS NOS ACORDOS PREFERENCIAIS DE COMÉRCIO - PTAS}

BIANCA TONELLI

Dissertação apresentada ao Programa de PósGraduação em Relações Internacionais do Instituto de Relações Internacionais da Universidade de São Paulo, para a obtenção do título de Mestre em Ciências - Programa de Pós-Graduação em Relações Internacionais

Orientador: Prof. Dr. Yi Shin Tang

São Paulo

2015 
UNIVERSIDADE DE SÃO PAULO

INSTITUTO DE RELAÇÕES INTERNACIONAIS

PROGRAMA DE PÓS-GRADUAÇÃO EM RELAÇÕES INTERNACIONAIS

\title{
DIVERGÊNCIAS NAS POLÍTICAS DE COMÉRCIO INTERNACIONAL NA AMÉRICA DO SUL: TENDÊNCIAS E DESAFIOS NOS ACORDOS PREFERENCIAIS DE COMÉRCIO - PTAS
}

\author{
BIANCA TONELLI
}

Dissertação apresentada ao Programa de PósGraduação em Relações Internacionais do Instituto de Relações Internacionais da Universidade de São Paulo, para a obtenção do título de Mestre em Ciências - Programa de Pós-Graduação em Relações Internacionais

Orientador: Prof. Dr. Yi Shin Tang

\section{Banca Examinadora:}

Prof. Dr. Yi Shin Tang (IRI - USP)

Prof. Dra. Maria Antonieta Del Tedesco Lins

Prof. Dr. Marcus Maurer de Salles 
FICHA CATALOGRÁFICA

TONELLI, Bianca

Divergências nas Políticas de Comércio Internacional na América do Sul: Tendências e Desafios nos Acordos Preferenciais de Comércio - PTAs

Orientador: Prof. Dr. Yi Shin Tang (IRI-USP)

82 páginas

Dissertação (Mestrado) - Universidade de São Paulo, 2015

América do Sul, Política de Comércio Internacional, Regionalismo, Acordos Preferenciais de Comércio, Tendências 


\section{AGRADECIMENTOS}

Agradeço a todos que, de longe ou de perto, contribuíram para que eu pudesse chegar à conclusão deste programa de pós-graduação em Relações Internacionais.

O ano de 2014 foi especialmente conturbado e encerrá-lo com essa missão cumprida é uma emoção indescritível.

À Comissão de Aperfeiçoamento de Pessoal de Nível Superior - CAPES, pelo apoio financeiro e ao Instituto de Relações Internacionais - IRI da Universidade de São Paulo USP, simplesmente por existir e possibilitar um ambiente de discussões de excelência em matéria de Relações Internacionais, enriquecendo a área no Brasil, fica registrado meu agradecimento. Ainda, agradeço imensamente a todo o pessoal da área administrativa do IRI, que não mede esforços para auxiliar os alunos, e que aqui faço representar por Giselle Castro, pessoa grande com um eterno brilho de criança impresso na alma.

Não há palavras suficientes para agradecer aos professores do IRI pelos ensinamentos. Fica a minha gratidão, em especial, ao meu Professor Orientador Dr. Yi Shin Tang pelo constante apoio e pela confiança no meu trabalho, às Professoras Dras. Deisy de Freitas Lima Ventura e Maria Antonieta Del Tedesco Lins pelas valiosas contribuições na fase de qualificação, à Professora Dra. Janina Onuki pelo incentivo a seguir em frente e ao Professor Dr. Umberto Celli Junior pelas aulas inspiradoras em matéria de Comércio Internacional.

No rol de professores que gostaria agradecer, incluo os participantes da Banca Examinadora: Professora Dra. Maria Antonieta Del Tedesco Lins e Professor Dr. Marcus Maurer de Salles, que disponibilizaram seu tempo para não somente avaliar, mas também para contribuir com suas opiniões acerca do estudo em foco, agregando caminhos para ampliá-lo no futuro.

A todos os colegas com quem tive o prazer de dividir a vida acadêmica, também seguem meus agradecimentos, e às colegas Ana Ong, Mariana Bernussi e Thalita Franco registro a minha alegria em poder chamá-las de amigas. Ainda, a Nathalie Tiba Sato, agradeço muitíssimo pelo apoio técnico e incentivo em momento crucial da pesquisa.

Agradeço às minhas irmãs de sangue Gabriela e Camila que mesmo de longe fazem parte do meu dia-a-dia e, também, a minha "sorella" de coração Beatriz, pois ver seu desempenho na esfera acadêmica me faz enxergar que é possível.

À minha mãe Rosane e ao meu pai Rogério agradeço por me fazerem exatamente quem sou e conto com vocês para me guiarem de onde quer que entejam. 
Minha companheira que se manteve fiel ao meu lado durante o desenvolvimento da redação do presente trabalho merece todo o agradecimento do mundo por encher minha vida de alegria: Obrigada, Paris!

Quero, por fim, agradecer ao meu marido André, pelo apoio incondicional que foi mais do que essencial neste processo. Teu amor e confiança foram meu incentivo número um para cumprir essa missão até o fim. Deste modo, dedico essa conquista a você, meu companheiro da vida. 
Deus salve a América do Sul

(...)

Desperta a América do Sul

(...)

(Ney Matogrosso) 


\section{LISTA DE QUADROS}

Quadro 1 - Medidas de Defesa Comercial na América do Sul - 2009 a 2013

Quadro 2 - Ranking Democracia

Quadro 3 - PTAs Colômbia - Acordos em vigor

Quadro 4 - PTAs Peru - Acordos em vigor

Quadro 5 - PTAs Chile - Acordos em vigor

Quadro 6 - PTAs Brasil, Argentina, Paraguai e Uruguai - Acordos em vigor

Quadro 7 - PTAs do MERCOSUL com países de outros continentes

Quadro 8 - PTAs Venezuela, Bolívia e Equador - Acordos em vigor

Quadro 9 - Acordos de Brasil ou MERCOSUL na ALADI 


\section{LISTA DE FIGURAS E GRÁFICOS}

Figura 1 - Colômbia e parceiros com FTAs em vigor antes de 2009

Figura 2 - Colômbia e parceiros com FTAs em vigor

Figura 3 - Peru e parceiros com FTAs em vigor - todos após 2009

Figura 4 - Chile e parceiros com FTAs em vigor antes de 2009

Figura 5 - Chile e parceiros com FTAs em vigor

Figura 6 - Mapa sobre participação em PTAs pelos países da América do Sul

Gráfico 1 - Tendência crescente do uso de FTAs

Gráfico 2 - Tendência de redução do uso de UAs

Figura 7 - Novas Alianças Regionais de Comércio 


\section{SUMÁRIO}

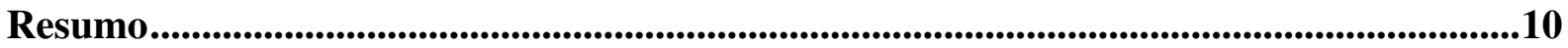

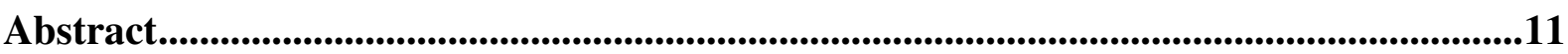

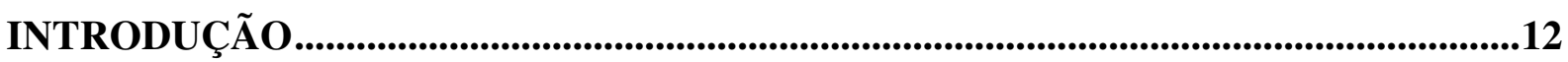

1 Política de Comércio Internacional na América do Sul .......................................................18

1.1. Do Integracionismo ao Pragmatismo ..................................................................... 18

1.1.1 A Centralidade do Comércio no Regionalismo - Uma Tendência Oscilante..........26

1.2 Sobreposição das ações integracionistas - um Spaghetti Bowl na América do Sul?.....28

1.3 América do Sul dividida em três vertentes de política de comércio internacional .........31

1.3.1 A visão Liberal-Bilateralista e seus representantes ...............................................36

1.3.2 A visão Regional-Multilateralista e seus representantes .......................................40

1.3.3 A visão Extremo-nacionalista e seus representantes ...........................................42

2 Tendências de Política de Comércio Internacional na América do Sul.........................46

2.1 Premissas Metodológicas ..........................................................................................46

2.2 Análise dos Acordos Preferenciais de Comércio - PTAs ................................................48

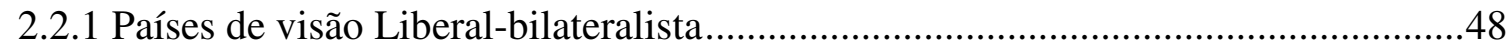

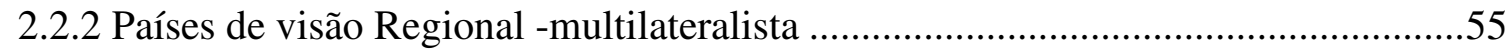

2.2.3 Países de visão Extremo-nacionalista .................................................................58

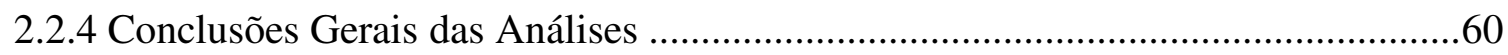

$3 \mathrm{O}$ Brasil e o desafio das tendências evidenciadas.....................................................64

3.1 A fidelidade à região da América do Sul ...................................................................64

3.2 A tímida integração comercial com os BRICS ..........................................................67

$3.3 \mathrm{O}$ multilateralismo e o MERCOSUL como prioridade .............................................69

3.4 O novo olhar da região ao Pacífico e os desafios para o MERCOSUL ...........................70

3.5 Novos projetos de integração regional e a exclusão do Brasil ......................................72

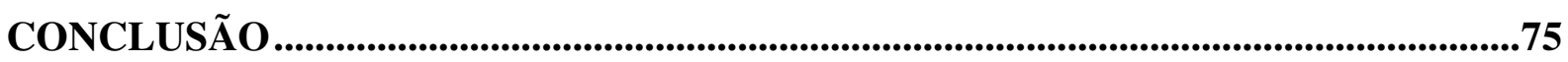

POSSÍVEIS DESDOBRAMENTOS DE PESQUISA ........................................................77

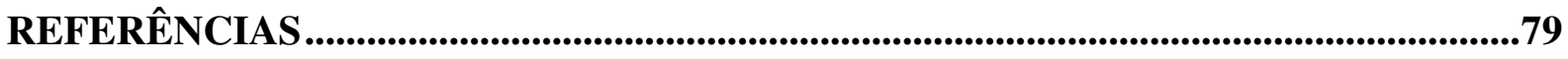




\title{
DIVERGÊNCIAS NAS POLÍTICAS DE COMÉRCIO INTERNACIONAL NA AMÉRICA DO SUL: TENDÊNCIAS E DESAFIOS NOS ACORDOS PREFERENCIAIS DE COMÉRCIO - PTAS
}

\begin{abstract}
Resumo
A América do Sul, na história recente, foi palco de diversas ações de integração regional relacionadas ao comércio, influenciando os posicionamentos dos países em matéria de políticas de comércio internacional bem como formando um emaranhado de relações que se sobrepõe muitas vezes de formas contraditórias. Neste contexto, a presente dissertação aborda o histórico das principais blocos regionais que envolvem a América do Sul como base para mostrar a atual fragmentação deste subcontinente em três visões principais de política de comércio internacional, sendo uma visão intermediária caracterizada pelo Brasil e acompanhada pelos membros do MERCOSUL em uma vertente regional-multilateralista. Em um extremo estão Venezuela, Equador e Bolívia, representantes da ALBA, com seus governos de posicionamento extremo-nacionalista. E em posição antagônica a estes estão Chile, Peru e Colômbia, que conformam o eixo liberal-bilateralista. Objetivando comprovar que há uma tendência de fortalecimento da visão liberal-bilateralista na região será feito um estudo com base nas suas principais formas de atuação, ou seja, por meio da análise de Acordos Preferenciais de Comércio, mais especificamente FTAs bilaterais celebrados com países de distintas regiões com foco especial ao período imediatamente após a eclosão da crise de 2008, de 2009-2014. Finalmente, se a hipótese se confirmar, restando evidenciada a retomada do posicionamento bilateralista, após período de predominância da visão multilateralista na América do Sul, é importante apontar os desafios para o Brasil neste cenário.
\end{abstract}

Palavras-chave: América do Sul, Política de Comércio Internacional, Regionalismo, Acordos Preferenciais de Comércio, Tendências 


\title{
DIFFERENCES IN INTERNATIONAL TRADE POLICIES \\ IN SOUTH AMERICA: TRENDS AND CHALLENGES \\ IN PREFERRENTIAL TRADE AGREEMENTS - PTAS
}

\begin{abstract}
South America, in recent history, has had several regional integration actions related to trade, influencing the countries positions in terms of international trade policies as well as forming a tangle of relationships that often overlaps with contrary views. In this context, this thesis addresses the history of the main regional blocs involving South America as a basis to show the current fragmentation of this subcontinent in three main views of international trade policy, with an intermediate vision characterized by Brazil and followed also by members of the MERCOSUR in a regional-multilateralist position. At one extreme, the countries Venezuela, Ecuador and Bolivia, ALBA representatives, present their extreme-nationalist position. And in an antagonistic position, Chile, Peru and Colombia constitute the liberalbilateralist axis. In order to prove that there is a trend towards the strengthening of the liberalbilateralist vision in the region, a research based on analysis of Preferential Trade Agreements will be held, focusing bilateral FTAs concluded with countries of different regions with special attention to the period immediately after the outbreak of the 2008 crisis, from 2009 to 2014. Finally, if the hypothesis is confirmed, demonstrating the resumption of the bilateralist position after a period in which the multilateralist vision was predominant in South America, it is important to point the challenges of this scenario for Brazil.
\end{abstract}

Keywords: South America, International Trade Policy, Regionalism, Preferential Trade Agreements, Trends 


\section{INTRODUÇÃO}

\section{Introdução geral}

A partir da segunda metade do século XX surge uma série de ações integracionistas regionais na América do Sul, demonstrando interesse, por um lado, em uma atuação internacional conjunta e coordenada e, por outro, no fomento do desenvolvimento interno da própria região. Desde o período no qual se iniciam estas tentativas de integração até o presente, porém, a proliferação de ações de regionalismo é tão intensa que resulta em um emaranhado de relações entre os países sul-americanos e também deles com outros países.

Assim, o regionalismo sul-americano é abordado brevemente com um enfoque histórico. Ainda, destaca-se a relação do regionalismo com o comércio, analisando os objetivos e abrangência dos principais blocos de integração ligados a esta área geográfica. Apesar dos esforços integracionistas, não há um posicionamento sul-americano uniforme. $\mathrm{O}$ que se identifica na região é diferentes visões de política de comércio internacional nesta subregião, as quais serão interpretadas por meio da análise dos padrões dos Tratados Preferenciais de Comércio (PTAs) dos quais os países em foco são parte.

Deste modo, objetiva-se responder se há uma tendência predominante em matéria de política de comércio internacional na América do Sul, questionamento para o qual se tem a hipótese de um fortalecimento da tendência à visão Liberal-bilateralista, por meio do recente recurso a negociações internacionais preferenciais de comércio. Com a confirmação desta hipótese, despontam os desafios que esta estratégia de política de comércio internacional traz especialmente ao Brasil, tradicional representante de uma visão voltada ao multilateralismo.

A delimitação do tema da dissertação que aqui se apresenta ocorreu de forma gradativa no decorrer das pesquisas, conseguindo-se, de imediato, estreitar a questão geográfica - América do Sul, mais especificamente os países que vieram a ser classificados em cada um dos três grupos representantes dos diferentes posicionamentos em matéria de política de comércio internacional, incluindo: Colômbia, Peru e Chile - com posicionamento Liberal-bilateralista; Brasil, Argentina, Paraguai e Uruguai - os quais adotam a visão Regional-multilateralista; Venezuela, Bolívia e Equador - representantes da vertente Extremo-nacionalista. Foi à dificuldade de tratar de Análise de Política Externa sem um ponto focal específico e o alcance do tema que resultaram no estreitamento da análise para políticas de comércio internacional, chegando-se ao exame do banco de dados de PTAs registrados perante a Organização Mundial do Comércio (OMC), abrangendo a listagem completa deste 
tipo de acordos, sem restrição temporal, de forma a confirmar o padrão adotado pelos países classificados conjuntamente, assim como a comprovar empiricamente a tendência em visão de política de comércio internacional no continente sul-americano.

Para que fique claro o teor do presente estudo, é de grande importância destacar que não foi tratada a política externa em geral, ficando a temática limitada às políticas de comércio internacional na América do Sul, conforme definições terminológicas apresentadas no próximo item. Na primeira parte desta pesquisa, é trazida uma breve introdução histórica com relação às tentativas integracionistas ocorridas na região, com foco na sua relação com as políticas de comércio internacional e com o próprio comércio, evidenciando-se um emaranhado de relações sobrepostas que servem de panorama para a definição e classificação de três vertentes principais de política de comércio internacional na região. Referidas vertentes são definidas e os países em estudo são classificados dentre elas, sendo divididos em três grupos distintos.

A segunda parte do estudo leva em conta os distintos posicionamentos de países sulamericanos em política de comércio internacional evidenciados em ações tomadas pelos Estados, em especial nos acordos de livre comércio bilaterais, que vem comprovar a tendência que se mostra em crescimento, bem como os desafios por daí emanados, em especial para o Brasil.

Desta maneira, este trabalho tem como objeto o estudo das três principais vertentes de política de comércio internacional da atualidade na região da América do Sul, havendo sido realizado por meio do procedimento de revisão bibliográfica e documental, buscando na literatura nacional e estrangeira as mais relevantes referências no tema, incluindo, mas não se limitando a livros e artigos em revistas especializadas. Salienta-se, ainda, que citações aparecem tanto no idioma original, quando vertidas para português e, neste último caso, tratase de versões livres da autora.

Com referência a pesquisa documental, utilizou-se documentos oficiais, como tratados, incluindo os tratados internacionais constitutivos de blocos econômicos regionais e organizações internacionais, bem como outros tratados internacionais diversos, em especial aqueles que abordam o comércio internacional, além de publicações internas dos países cujas políticas são objeto de pesquisa. Foi, ainda, amplamente explorada a base de dados da OMC que abriga as notificações sobre acordos preferenciais de comércio.

Por fim, deseja-se por meio deste estudo comprovar que há, atualmente, na América do Sul, uma heterogeneidade com relação às visões de políticas de comércio internacional adotadas pelos países, identificando qual a tendência predominante. A hipótese é que há uma 
recente retomada da visão Liberal-bilateralista, que desafia a visão Regional-multilateralista tradicionalmente adotada pelo Brasil.

\section{Conceitos e terminologias}

A definição de alguns conceitos e terminologias faz-se necessária para que se compreenda a abordagem do presente estudo. São destacados, neste ponto, o entendimento aplicável a Política Externa e sua análise, bem como a sua delimitação mais específica em Política de Comércio Internacional.

A Política Externa consiste em um "conjunto de atividades políticas, mediante as quais cada Estado promove seus interesses perante os outros Estados" (WILHELMY apud OLIVEIRA, 2008. p. 5), ou frente a outras organizações ou atores na arena internacional. Ocorre que os interesses das nações não são estáticos e estão diretamente atrelados às conjunturas internacionais e às alterações de poder neste cenário. É por esta razão que a interação entre países, seja por meio de blocos regionais ou individualmente, pode exercer influência direta na sua atuação em face aos demais países.

Nem sempre o processo decisório, a diversidade temática e a dinâmica política estiveram presentes nos estudos de política externa (MILANI; PINHEIRO, 2013, p.13). Hoje, a política externa abrange cada vez mais áreas distintas, pois os temas objeto da atuação dos Estados vêm se ampliando sob a influência da conscientização e participação dos cidadãos e, principalmente, pelo alcance da globalização a assuntos antes tratados exclusivamente no plano doméstico. Assim, emerge na análise de política externa a abordagem de assuntos como saúde, meio ambiente, educação, cultura, cooperação, direitos de grupos específicos da sociedade, entre uma lista que jamais poderia ser exaustiva, uma vez que a dinamicidade é característica inerente à política externa.

Apesar de diversos novos temas participarem do foco múltiplo da Análise de Política Externa (APE) contemporânea no Brasil, na América do Sul e no mundo, temas tradicionalmente tratados nesta esfera mantém sua relevância. Entre eles está o objeto do presente estudo que é o Comércio Internacional.

O que outorga especificidade à APE é seu foco nas ações internacionais de unidades particulares. Com efeito, a APE tem como objeto o estudo da política externa de governos específicos, considerando seus determinantes, objetivos, tomados de decisões e ações efetivamente realizadas (SALOMÓN; PINEHIRO, 2013, p.40).

Neste estudo, os governos específicos são os governos dos países da América do Sul e, entre os determinantes de política externa de Comércio Internacional está a participação 
destes Estados sul-americanas em blocos regionais cujos acordos podem guardar relação com o comércio em seu escopo.

Apesar de o enfoque estar no Estado como agente de política externa no âmbito internacional, é essencial mencionar que a APE já reconhece uma gama muito mais ampla de atores domésticos envolvidos na política externa de um Estado, sejam eles atores governamentais: Poder Executivo Federal, agências do Governo, sejam elas federais, regionais ou locais, entidades subnacionais, tais como Estados e Municípios, Poder Legislativo e Poder Judiciário; ou não governamentais: partidos políticos, organizações não governamentais (ONGs), organizações empresariais, sindicatos, meios de comunicação e opinião pública, grupos da sociedade civil (MILANI, 2012, p. 39). "Resulta que, nos dias de hoje, se tenha tornado inegável e ainda mais presente a conexão entre problemas internacionais e temas de natureza doméstica" (PINHEIRO; MILANI, 2012, p. 16), e, desta forma, esses atores nacionais têm sua participação globalmente fortalecida na política externa.

Ainda nesse sentido, a política externa é uma política pública com uma característica específica, o fato de ser implementada fora das fronteiras estatais. Assim, no processo de elaboração de política externa como política pública incidem demandas e conflitos de variados grupos domésticos, como ocorre com qualquer outra política pública. (SALOMÓN. PINHEIRO, 2013, p. 41)

A abordagem na análise de política externa pode ser vinculada às perspectivas teóricas da disciplina das Relações Internacionais. Logo, por meio de uma abordagem realista, o enfoque está na estrutura anárquica do sistema e sua distribuição de poder; enquanto a contribuição liberal coloca os fatores internos no centro das explicações. Já uma análise construtivista reforça uma dimensão cognitiva.

Por outra parte, embora a APE seja, como vimos, compatível tanto com explicações realistas, que dão mais peso aos fatores sistêmicos na explicação de políticas externas, quanto com explicações liberais, que postulam a preponderância dos fatores domésticos, é importante salientar que boa parte dos autores que trabalham com a APE permanecem neutros a esse respeito, deixando que a pesquisa empírica decida, para cada caso específico, que tipo de fatores teve peso maior. (SALOMÓN; PINEHIRO, 2013, p. 48)

Fugindo do determinismo das teorias das Relações Internacionais, a pesquisa empírica figurará no centro da presente análise de política externa em tema de comércio internacional.

Para fins do presente estudo, Política de Comércio Internacional é sinônimo de política comercial externa que segundo Oliveira é compreendida como o campo da política externa voltado para temas da agenda comercial, com foco particular nas negociações comerciais de um país com os outros, seja no âmbito bilateral e regional, seja no multilateral, mas que 
também abrange aspectos relativos à promoção comercial (OLIVEIRA, 2012, p. 10). Deste modo, política externa é o gênero do qual a política de comércio internacional é espécie.

O comércio exterior de um país trata especificamente das operações de importação e exportação, bem como das normas adotadas no sistema jurídico interno com referência a tais operações, com um enfoque aduaneiro, e não político.

Embora o termo Comércio Exterior, ou Foreign Trade, na língua inglesa, seja amplamente difundido e mais largamente utilizado, tanto no campo acadêmico quanto na linguagem comum, o objeto do presente estudo ultrapassa questões relativas à normativa interna de cada país com relação ao comércio. Muito além de regras ou legislações específicas a serem aplicadas a importações e exportações, trata-se aqui das relações internacionais de um país no campo do comércio internacional.

Por sua vez, o termo Comércio Internacional, ou, International Trade, em inglês, pode ser confundido com o próprio Sistema Multilateral de Comércio, vigente por meio da Organização Mundial do Comércio - OMC. Embora a OMC exerça forte influência no Comércio Internacional, em especial na sua regulação, aborda-se aqui o regionalismo na América do Sul e sua relação com o comércio, com um enfoque em ações integracionistas locais e não naquela organização internacional de abrangência global.

Ainda, é de extrema valia ressaltar que o assunto explorado neste estudo não reside nas teorias econômicas dos de termos de troca, que também é usualmente objeto de estudo do comércio internacional.

Fez-se a opção pelo uso do termo Comércio Internacional, justificado no fato de que se está abordando blocos regionais, que estabelecem acordos e consequentes regras aplicáveis a mais de um país. Tornar-se parte de um bloco de integração regional, por si só, já significa uma decisão acerca da atuação de determinado país na esfera internacional. Contudo, apesar da conotação internacional, essa decisão é tomada internamente, ou seja, cada Estado definirá se será ou não parte de uma ação integracionista de acordo com seus interesses, formando, por conseguinte, uma decisão de política externa.

A política externa voltada ao comércio internacional, referindo-se às ações de um país na esfera do comércio em âmbito internacional será chamada, por fim, de Política de Comércio internacional. Para que o termo escolhido não seja repetido infindáveis vezes no decorrer deste trabalho, deve-se entender política, política externa, política comercial, política comercial internacional, neste mesmo sentido, exceto quando especificado de outra forma.

Uma vez que políticas se refletem em ações, para a colocada em prática de políticas comerciais em âmbito internacional há instrumentos específicos definidos no escopo da 
Organização Mundial do Comércio (OMC), como tarifas, quotas, salvaguardas, medidas compensatórias, antidumping, entre outros. Esses instrumentos específicos e seu uso tampouco fazem parte do escopo deste trabalho, pois o mesmo está centrado em questões mais gerais de política de comércio internacional, tendo em conta a inserção em processos de integração que englobem a América do Sul, para que na segunda parte do estudo seja possível traçar tendências da atuação dos países sul-americanos em matéria de política de comércio internacional. 


\section{Política de Comércio Internacional na América do Sul}

\subsection{Do Integracionismo ao Pragmatismo}

Para uma abordagem histórica da integração econômica por meio de blocos regionais na América do Sul, destaca-se a década de 1960, que marca o surgimento da Associação Latino-Americana de Livre Comércio - ALALC. É importante ressaltar que nesta época o mundo já estava inserido no contexto multilateralista iniciado com o General Agreement on Tariffs and Trade - GATT em 1947 (posteriormente transformado em Organização Mundial do Comércio - OMC em 1995). Assim, quando da instituição da ALALC, os países latinos enfrentavam o desafio de ver nascerem blocos regionais de integração em outros confins no final da década de 1950, como o Mercado Comum Europeu, datado de 1957 (que em 1993 passou a União Europeia).

A referida iniciativa europeia gerou protestos junto ao GATT, contra as discriminações tarifárias e não-tarifárias de que seriam vítimas os países da América Latina, classificando a integração no velho continente como atentado aos princípios originais do sistema multilateral. Não havia, por conseguinte, outro caminho a ser seguido, que não fosse voltar seu foco para a própria região da América Latina, tendo essa orientação de política externa base em inúmeros fatores, como a decepção pela negligência dos Estados Unidos com a América Latina que chamava a uma tomada de consciência e uma nova atitude; o reordenamento das relações internacionais para enfrentar os problemas do atraso e do desenvolvimento dos povos que se impunha como oportuno após a reconstrução europeia e a estabilização política internacional; a criação de uma união aduaneira na Europa e desta com suas colônias que reclamava a união das Américas; o pensamento cepalino ${ }^{1} \mathrm{e} o$ desenvolvimentismo que exigiam uma crescente de cooperação internacional (CERVO, 1997, p. 10).

Em 1958, ainda antes de adentrar à integração econômica propriamente dita na América do Sul, deve-se mencionar a Operação Pan-Americana - OPA, proposta pelo presidente Juscelino Kubitschek que figura como primeiro passo em direção à integração no continente americano. Apesar de não haver concretizado avanços reais, foi o início de uma visão multilateral-regionalista por parte do Brasil. Foi por meio do lançamento da OPA que a retórica diplomática brasileira passou a centrar-se claramente na ideia de identificação do

\footnotetext{
${ }^{1}$ Cepalino, termo proveniente de CEPAL - Comissão Econômica para a América Latina e Caribe, no âmbito da Organização das Nações Unidas.
} 
Brasil com seus vizinhos latino-americanos, como confirmou o Relatório do Ministério das Relações Exteriores de 1958:

Trata-se ${ }^{2}$ do maior esforço diplomático do Brasil em 1958 e, por outro lado, é o primeiro movimento iniciado por nosso país no cenário continental, com base num estado de consciência verdadeiramente latino-americano (RMRE, 1958, p. 3, apud SANTOS, 2014, p. 96).

Desta forma, a política brasileira essencialmente bilateralista, como país aliado especial dos Estados Unidos, foi substituída por um enfoque centrado nas relações multilaterais que podia ser identificado, além da própria OPA, na maior participação na Organização dos Estados Americanos - OEA $^{3}$, com a valorização do Conselho Interamericano Econômico; na intensificação da participação na Organização das Nações Unidas - ONU, inclusive na Cepal, e também, no contexto latino-americano, na criação da ALALC (SANTOS, 2014, p.97).

Em 1960, a ALALC foi como a primeira grande tentativa de integração regional que envolve a América do Sul a ser destacada, estabelecida por meio do Tratado de Montevidéu, firmado por Argentina, Brasil, Colômbia, Chile, Equador, México, Paraguai, Peru, Uruguai e Venezuela, objetivando estabelecer uma Zona de Livre Comércio entre os países da América Latina, por meio da redução de barreiras ao comércio entre seus membros. Uma zona de livre comércio consiste na abertura recíproca dos mercados, porém sem a necessidade de uma política comum. No entanto, assumir o compromisso de abertura de mercado por si só já faz parte de um posicionamento de política de comércio internacional adotado por determinado país.

Embora o entendimento predominante de que o modelo de substituições de importação seria o grande responsável pelo insucesso da Associação, há quem discorde, defendendo que o referido modelo correspondia a uma racionalização do processo de proteção e expansão industrial, sem conflito aberto com a negociação comercial ou com a integração regional, uma vez que a sua filosofia era de promover mudanças estruturais na economia da região (CERVO, 1997, p. 10).

De todo modo, percebe-se que o discurso liberal inerente ao pensamento latinoamericano não apresentava e não mais apresentaria, dos anos cinquenta aos oitenta, coerência com políticas comerciais que eram marcadamente protecionistas (PORCILE, apud CERVO, 1997, p. 11).

Os anos de 1970 não apresentaram avanços relevantes em direção à integração regional, pelo contrário, mostravam indícios de estagnação. Na referida década, depois de

\footnotetext{
${ }^{2}$ A OPA

${ }^{3}$ OEA ou OAS, em inglês, Organization of American States, organismo internacional voltado à segurança
} 
alcançar alguns resultados por meio da concessão de preferências nos primeiros anos após sua instituição,

\begin{abstract}
a ALALC caía em descrédito e o termo integração passaria a ter uma conotação mais política que comercial, aliás passaria frequentemente a expressar toda e qualquer iniciativa em andamento na América Latina - diplomática, política, estratégica, econômica, cultural etc. - o que evidenciava a desqualificação do conceito. O declínio do termo e do conceito integração ocorreria na linguagem diplomática brasileira em tendência contrária à ascensão e valoração do termo cooperação, que abrigava tanto o desempenho do multilateralismo, considerado sofrível, quanto do bilateralismo, crescentemente promissor (CERVO, 1997, p. 11).
\end{abstract}

Foi então que o Tratado de Montevidéu de 1980 instituiu a Associação LatinoAmericana de Integração - ALADI, substituindo a ALALC, conforme expresso no último parágrafo de seu preâmbulo. Entende-se, portanto, que a ALADI é a continuação da ALALC, com a renovação do propósito de integração da região da América Latina. Por meio do novo tratado, a ALALC deixa de existir e é integralmente transformada em ALADI, visando o estabelecimento de um mercado comum na região.

A experiência da ALAC, conforme Prazeres (2006) foi de grande valia para a conformação da ALADI nos seus moldes.

Não obstante isso, é preciso admitir que, apesar de não ter sido possível a conformação da área de livre-comércio tal como preconizada pela Alalc, a experiência relacionada a ela legou lição importante para as iniciativas que a sucederam. Ao mesmo tempo em que o processo contribuiu para despertar a consciência a respeito das potencialidades coletivas, das complementaridades possíveis e das responsabilidades conjuntas dos Estados da região, a experiência serviu para evidenciar as fragilidades da cooperação sub-regional. $O$ processo histórico de construção de uma área de livre-comércio nos moldes previstos pela Alalc contribuiu para que a proposta que lhe foi superveniente fosse menos divorciada da realidade, logo, mais próxima das circunstâncias latino-americanas. A experiência, sem dúvida, alterou a percepção dos atores a respeito da integração subregional e, de alguma maneira, o novo regime estabelecido pela Aladi foi moldado por essa nova percepção (PRAZERES, 2006, p. 26).

A ALADI é uma instituição que conseguiu permanecer em vigor através do tempo e conta com treze membros, os quais são Argentina, Bolívia, Brasil, Chile, Colômbia, Cuba, Equador, México, Panamá, Paraguai, Peru, Uruguai e Venezuela. Embora a ALADI seja uma organização da América Latina e esteja aberta à participação dos países desta região como um todo, é uma associação de relevância nomeadamente para a América do Sul, pois dos treze países membros, dez são países sul-americanos, sendo todos eles membros fundadores da associação. O significado disso é que a ALADI mostra-se essencialmente sul-americana, englobando quase todos os países da sub-região, deixando somente dois deles de fora, a Guiana e o Suriname.

Embora não se aproxime de atingir o seu objetivo, a ALADI consegue criar uma área de preferências econômicas, baseada em preferências tarifárias entre seus signatários, 
fomentando o comércio entre os mesmos. Ressalta-se, ainda, que a ALADI está aberta à adesão dos países latino-americanos ${ }^{4}$ que não são membros e também incentiva acordos com países não membros ou áreas de integração econômica da região. Não se pode negar que a ALADI alcança resultados em questão de preferências tarifárias, sendo que além do Acordo de Preferências Tarifárias Regional, que traz benefícios a todos os países da organização, existem os Acordos de Complementação Econômica, que fomentam o comércio da região.

No final da década de 1960, outra importante ação na direção da integração sulamericana foi o Pacto Andino, instituído pelo Acordo de Cartagena, firmado por Bolívia, Colômbia, Chile, Equador e Peru. Desde sua constituição em 1969, o bloco teve sua configuração alterada ao longo do tempo, com a entrada da Venezuela em 1973, e com a retirada do Chile em 1976, e a posterior saída da Venezuela em 2006, mostrando sua oscilação entre avanços e retrocessos com relação à participação da região. Conforme se abordará mais à diante, no final da década de 1990 o Pacto Andino é extinto com sua substituição pela Comunidade Andina das Nações - CAN.

Em 1991, foi criado o Mercado Comum do Sul - MERCOSUL, por meio da assinatura do Tratado de Assunção, entre Argentina, Brasil, Paraguai e Uruguai. A criação do MERCOSUL exprime uma visão de regionalismo aberto, trabalha a compatibilidade da agenda interna e externa da modernização que chega como necessidade ao Brasil e Argentina com o fim do modelo do Estado e da economia baseado na substituição de importações. É, ainda, um marco de referência democrática dos países que o integram. (LAFER, 2001, p. 59.)

A associação de Brasil e Argentina parece um caminho lógico a ser seguido, tendo em vista a expressividade de ambos os países dentro da região, porém a participação de Paraguai e Uruguai diante desses dois gigantes é prenúncio de problemas de assimetria, em contrapartida, contempla questões políticas, fortalecendo o bloco. $\mathrm{Na}$ realidade, os grandes beneficiários desta situação no cenário internacional, são justamente os países menores, que por pertencerem ao MERCOSUL são ouvidos internacionalmente com maior atenção ao se colocarem ao lado de Brasil e Argentina (GUIMARÃES, 2012. p. 95). O MERCOSUL simboliza, portanto, uma nova presença da América do Sul no mundo pós-guerra fria e é fator importante, em negociações econômicas interamericanas, apresentando-se mais forte frente ao projeto ALCA e às integrações europeias (LAFER, 2001, p. 60).

Estendendo-se a outros países da América do Sul, o MERCOSUL tem como Estados associados todos os membros da CAN e também o Chile. Além disso, mais recentemente, em

\footnotetext{
${ }^{4}$ Conforme artigo 57 do Tratado de Montevidéu de 1980.
} 
2012, a Venezuela ingressou ao bloco, configurando a primeira ampliação desde seu início, porém em um contexto político bastante contraditório, no qual o Paraguai, historicamente contrário à entrada da Venezuela, havia sido suspenso devido à destituição de seu presidente, considerada ilegítima pelo bloco. Foi a oportunidade, portanto, para a entrada da Venezuela, que encontrava como empecilho somente a falta de aprovação do Congresso Paraguaio. Após a entrada da Venezuela, foi a vez da Bolívia, que já era um país associado e por meio de Protocolo de Adesão passou a Estado Parte em processo de adesão, portanto, aguarda somente a incorporação do Protocolo de Adesão a todos os ordenamentos jurídicos dos Estados Parte para tornar-se membro pleno. Assim, o MERCOSUL ganha membros, ampliando a sua representatividade na América do Sul, porém traz ao seu seio visões políticas distintas, que podem vir a dificultar futuras decisões.

Também no início da década de 1990, os Estados Unidos, juntamente com Canadá e México, formam o Acordo de Livre Comércio da América do Norte - NAFTA. Ao abarcarem o México, há uma quebra na visão una de América Latina, o que fortalece o conceito de fragmentação desta região, dividindo-a em América do Norte, associada por meio desta proposta; América Central e Caribe, já com fortes influências dos Estados Unidos bem como com acordos de liberalização comercial com este país; e América do Sul, que diante disso tem como solução unir-se. É neste momento que se tem o conceito de América do Sul, pois, em contraponto ao NAFTA, o Brasil no governo Itamar Franco lança a ideia da ALCSA, ou Área de Livre Comércio da América do Sul (COSTA, 2013. p. 238), que não foi adiante, porém que configura um espectro da política externa brasileira já mais focado na sub-região.

Os EUA, então, em 1994, propõem a Área de Livre Comércio das Américas - ALCA, com cunho meramente comercial, abrangendo todos os países das Américas e objetivando oficialmente integrar a toda a região, porém, visando de fato ampliar o seu acesso aos mercados, mantendo sua relação de poder a exemplo do que já ocorria na América Central. Assim, o posicionamento do Brasil frente a esta proposta de integração sob a hegemonia americana é de refuta e tal proposta restou arquivada.

Apesar de haver gerado avanços efetivos a partir do final da década de 1980, com o fim do modelo de substituição às importações, chegando a uma zona de livre comércio entre seus membros em 1993, o Pacto Andino foi extinto, sendo substituído pela Comunidade Andina de Nações - CAN, em 1997. A CAN é um bloco eminentemente sul-americano, contando como membros com Bolívia, Colômbia, Equador e Peru, visto que houve a retirada da Venezuela em 2006, quando a mesma buscou outro caminho para a integração na América do Sul aproximando-se do MERCOSUL. 
Este movimento da Venezuela de saída de uma instituição de integração regional, no caso a CAN, para a busca de inserção em outra, que foi o MERCOSUL, pode trazer uma ideia de incompatibilidade entre ambas. Embora seja possível afirmar que a existência de consideráveis diferenças ideológicas e políticas entre alguns dos membros dessas duas organizações, juridicamente não há qualquer impeditivo de participação em ambas. Isso é reforçado pela Bolívia, membro pleno da CAN desde sua fundação como Pacto Andino, que foi o primeiro país latino americano a firmar acordo de complementação com o MERCOSUL em 1995, e que desde 2012 é membro em processo de adesão do MERCOSUL. O país, no entanto, terá que coordenar suas ações e políticas com ambos, o que pode ser um desafio.

No início do século XXI emergiu na América Latina mais uma ação integracionista, desta vez encabeçada por Cuba e Venezuela, países com forte viés socialista, em uma reunião entre Fidel Castro, então presidente de Cuba, e o presidente da Venezuela, Hugo Chávez, em 2004 na cidade de Havana. A chamada Aliança Bolivariana para os Povos da Nossa América - Tratado de Comércio dos Povos - ALBA-TCP, não é um bloco econômico regional, mas uma plataforma de integração para os países da América Latina e do Caribe, com foco na cooperação. A ALBA define-se como uma forma de integração e união da América Latina e do Caribe, com base em um modelo de desenvolvimento independente, com destaque para a complementaridade regional que permita promover o desenvolvimento de todos e fortalecer a cooperação através do respeito mútuo e da solidariedade.

Os países que atualmente compõem a ALBA são Venezuela, Cuba, Bolívia, Nicarágua, Dominica, Antígua e Barbuda, Equador e São Vicente e Granadinas, apresentando, desta forma, membros sul-americanos, porém, mostrando uma maior participação da América Central e Caribe. A Bolívia foi o terceiro país membro, aderindo a ALBA em 2006 e o Equador tem um vínculo mais recente com esta plataforma, iniciado em meados de 2009. Diversamente das demais ações integracionistas, que buscam a liberalização do comércio na região em concordância com o Sistema Multilateral de Comércio, a ALBA, por ser dotada de forte ideologia esquerdista, prevê a cooperação de seus povos, porém, não a abertura de seus mercados. Pelo contrário, a ALBA mostra ter mais afinidade com o protecionismo de sua indústria, que com políticas que levam à liberalização.

Com a intensificação da globalização e da regionalização, fica claro que a integração seria o caminho para novas oportunidades de desenvolvimento na América do Sul, unindo as forças dos países da região (SIMÕES, 2012. p. 21). Desta forma, a UNASUL é o resultado de uma iniciativa genuinamente brasileira e os primeiros passos em sua direção surgem com a realização da Primeira Cúpula de países da América do Sul no ano 2000. As reuniões se 
repetiram e, como resultado, criou-se a Comunidade Sul-Americana de Nações - CASA - no ano de 2004. É em 2008 que a CASA transforma-se em UNASUL.

Assim, o início do novo milênio significou um movimento na Diplomacia brasileira com as condições nacionais, regionais e internacionais indicando que o melhor caminho para a consolidação do país nestes cenários seria a América do Sul (...) "o processo de formação da UNASUL é semelhante ao do MERCOSUL do ponto de vista de suas ambições e de seu caráter político, buscando uma melhor inserção internacional e a ampliação dos vínculos econômicos internos com viés funcionalistas" (COSTA, 2013. p. 239).

Embora haja realmente esses pontos convergentes, a UNASUL já nasce de forma essencialmente diversa do MERCOSUL. A UNASUL, na realidade diferindo de todas as demais tentativas integracionistas dentro da região, nasce com um viés menos mercantilista e mais voltado à cooperação, uma vez que seus primeiros passos foram na direção da integração física e energética resultantes das primeiras reuniões de cúpula. Assim como mencionado acerca da política externa que se amplia em termos de assuntos abrangidos, a cooperação segue a mesma tendência, abarcando também áreas específicas que ultrapassam fronteiras e passam a ser vistas como preocupações conjuntas de mais de um Estado, ou mesmo ganham condição de global.

Outra divergência entre a UNASUL se comparada ao MERCOSUL e outros blocos regionais está na falta de instituições da mesma. Enquanto os blocos regionais em geral se preocupam com sua institucionalização, a UNASUL opta por não ter estruturas institucionais, com característica intergovernamental, sem que haja cessão de soberania por parte dos países da região.

Mais uma iniciativa de integração envolvendo a região, o Fórum do Arco do Pacífico Latino-Americano - ARCO, cujo início oficial foi datado de 2007, pode ser considerado como uma instância de articulação política e econômica e um espaço de convergência, cooperação e integração. Ele merece ser citado, não em razão de avanços efetivos em relação à integração regional, mas por marcar a tendência de países limítrofes ao Oceano Pacífico em voltar sua atenção a esta área como forma de estreitar sua ligação com os países asiáticos. Esta ação integracionista está limitada geograficamente aos países que latinos ligados ao Oceano Pacífico, e tem como partes Chile, Colômbia, Costa Rica, Equador, El Salvador, Guatemala, Honduras, México, Nicarágua, Panamá e Peru.

Embora seu enfoque comercial não seja novidade, é novidade, no entanto, a ideia de constituir a primeira iniciativa dirigida a articular posições comuns frente aos países da Ásia e do Pacífico. O ARCO se destaca também como um espaço exclusivamente latino dos países que firmaram tratados de livre comércio com os Estados Unidos e a União Europeia, o que permite que seus membros se apresentem como favoráveis a uma abertura global, mas sem 
abandonar o compromisso com a região, neutralizando assim as críticas provenientes dos países da ALBA (RUIZ, 2010, p. 58).

Identifica-se novamente uma participação de países da América do Sul em mais de uma ação integracionista regional simultaneamente, posto que Colômbia, Equador e Peru já são membros da CAN desde que a mesma se constituiu em Pacto Andino em 1969. Ainda, Colômbia e Peru participam de mais uma ação regionalista, a Aliança do Pacífico.

Esta ação recente, datada de 2011, e também voltada para o Pacífico, surge com um pragmatismo que a difere substancialmente das demais ações de integração vistas na região. Na Aliança do Pacífico, os países membros não estão limitados à América do Sul, já que há a participação do México, além de Chile, Colômbia e Peru. A plataforma sobre a qual seu Acordo institucional está redigido é composta dos tratados de livre comércio (FTAs) na forma de acordos bilaterais existentes entre os membros. Os países se comprometem, por meio da Aliança, a avançar progressivamente até o objetivo de alcançar a livre circulação de bens, serviços, capitais e pessoas, ou seja, chegar a um mercado comum.

A Aliança do Pacífico nasce em um ambiente no qual seus membros já dispõem de acordos de livre comércio entre si. Ou seja, surge já com um grau importante de integração econômica e apresenta também objetivos políticos de servir como plataforma para a maior projeção de seus membros para a região da Ásia-Pacífico.

\begin{abstract}
As negociações em curso em 2013 para estabelecer uma área de livre-comércio comum da AP deveriam dar-lhe novo impulso, mas essa organização tem uma vocação de vinculação transregional: seguindo uma proposta de 2002, Chile, Singapura, Nova Zelândia e Brunei assinaram um Acordo de Associação Econômica de caráter transpacífico, em 2006, que serve de base às negociações de um ambicioso Acordo Transpacífico (TPP) de que, com os quatro países originais, participam Estados Unidos, Austrália, Peru, Malásia e Vietnã e a que se incorporaram México, Canadá e Japão (PORTALES, 2013, p. 219).
\end{abstract}

A Aliança não esquece a política, no entanto, há uma recuperação da economia e do comércio como essenciais para a integração, como demonstra o seu compromisso com o livre comércio e a conexão com outras áreas com regimes similares. (MALAMUD, 2012, p.5).

Finalmente, a mais recente ação que inclui países sul-americanos é o TPP, que engloba onze países sem que haja necessariamente a característica de proximidade geográfica, já que estão dispersos entre três continentes, incluindo Chile e Peru. O TPP também tem o comércio como seu núcleo, uma vez que sua proposta é justamente formar uma grande área de livre comércio de proporções intercontinentais. 
O Acordo Transpacífico - TPP $^{5}$ emana de membros do Foro de Cooperação Econômica Ásia-Pacífico - APEC e objetiva chegar a uma área de livre comércio de abrangência trans-regional. As negociações ocorrem de forma plurilateral, que consiste na determinação de um acordo geral para os interessados e posterior adesão para os países dispostos a aceitar seus termos pré-definidos.

Estas ações de integração que envolvem a América do Sul em um movimento direcionado ao Pacífico tem, portanto, relação estreita e direta com o comércio internacional, bem como com políticas de comércio internacional com as quais se comprometem suas partes na busca de seus objetivos de liberalização comercial.

\subsubsection{A Centralidade do Comércio no Regionalismo - Uma Tendência Oscilante}

É cada vez mais evidente a multidimensionalidade do regionalismo, dificultando a distinção entre regionalismo político e regionalismo econômico. Entende-se neste contexto que estas duas esferas, na realidade, não podem ser afastadas, mesmo quando se busca compreender o papel do comércio na integração, pois, por mais que o comércio disponha de conexão com a questão econômica, o universo político é muitas vezes decisivo em matéria de integração e em seu escopo está também a relação com os compromissos assumidos em questão de políticas comerciais internacionais.

Com referência à relação das ações integracionistas com as políticas de comércio internacional, trata-se de uma tendência oscilante, estando o comércio ora como foco central de referidas ações, ora exercendo papel periférico e, ainda, em certas ocasiões, restando fora do alcance da integração regional, quando se busca uma união mais voltada a questões políticas.

Desde a sua criação, após a Segunda Guerra Mundial, a integração regional girou em torno do comércio e da economia. Contudo, na última década a ênfase foi colocada na política, em especial na "coordenação política", conforme representado pela Unasul (MALAMUD, 2012, p. 2).

Neste sentido é importante estabelecer que as tentativas integracionistas, em geral, são bastante amplas e abrangentes, abarcando diversos assuntos e propósitos dentro de seu

\footnotetext{
${ }^{5}$ TPP - referente à sigla em inglês para Trans-Pacific Partnership.
} 
escopo. Enquanto na ALALC e ALADI o comércio pode ser considerado como núcleo do propósito de integração, no MERCOSUL tal relação também é encontrada, porém, a falta de resultados eficazes na consecução de um mercado comum, bem como as recentes alterações em sua configuração enfraquecem a questão comercial como cerne, conferindo uma conotação mais política a esta organização de integração regional.

Na ALBA é possível estabelecer uma relação entre o comércio e a instituição, conformada em seus documentos oficiais. Contudo, o comércio não ocupa espaço de relevância em comparação à cooperação, posto que a ideologia dos países da ALBA mostrase contrária à liberalização do comércio.

A UNASUL, por sua vez, que engloba praticamente toda a América do Sul traz o comércio em sua retórica, porém, não apresenta nenhuma proposta concreta neste tema. Neste sentido, entende-se a UNASUL como ação regional política, sem que haja uma relação direta ou concreta com o comércio. Trata Prazeres (2006) ao falar sobre a CASA, mesmo antes de sua transformação em UNASUL que as questões comerciais, que sempre estiveram no núcleo das propostas de integração sul-americana, não receberam grande destaque no projeto (PRAZERES, 2006, p.46).

As tentativas de integração regional envolvendo a área do Pacífico, com o ARCO, a Aliança do Pacífico e o TPP também trazem o comércio no centro de suas atenções, em especial por já haverem alcançado graus relevantes de integração, porém, não se limitam a ele, estabelecendo outras políticas também relevantes no marco de sua integração.

Percebe-se, neste cenário, que o regionalismo está sempre em movimento, com o surgimento, extinção e transformação das ações integracionistas na América do Sul ou de qualquer que seja a região. Esta dinamicidade, portanto, fará com que o comércio internacional e suas políticas apareçam periodicamente com mais destaque em meio às ações de integração, ora seja dada mais ênfase a questões meramente políticas ou focadas em temas pontuais.

Constata-se, então, que a centralidade do comércio internacional e suas políticas nas ações de integração regional que abrangem países da América do Sul é bastante evidente quando se inicia o regionalismo com a ALALC, visto que o interesse principal estava em formar uma área de livre comércio. Porém, na medida em que a integração avança no subcontinente nos anos setenta e oitenta, o comércio permanece como cerne da integração, contudo, a mesma passa a ser permeada por outros assuntos de interesse, com a ALADI e Pacto Andino/CAN. O MERCOSUL apresenta também o comércio como central entre seus interesses, porém, não deixa de ter uma questão política bastante evidente desde a sua 
formação, reunindo países de economias assimétricas na busca por estabelecer uma liderança regional por parte do Brasil. Despontam, então, regionalismos que não tem o comércio como questão central, como a ALBA e, recentemente, a UNASUL, conformando uma tendência de cooperação em assuntos diversos como previamente mencionado. Não obstante, essa tendência não se mantém e comércio retorna ao núcleo das ações de integração, com ARCO, AP e TPP, cujos países membros atuam de forma liberalista e buscam a abertura comercial.

O comércio internacional figura como fator impulsionador do regionalismo sulamericano. Porém, não se pode dizer que o mesmo é o ponto central de todas as instituições abordadas no presente estudo, havendo uma abrangência de mais temas em especial em ações mais recentes como a UNASUL.

\section{Sul?}

\subsection{Sobreposição das ações integracionistas - um Spaghetti Bowl na América do}

A coexistência de tantas ações regionalistas simultâneas tocantes à região da América do Sul, bem como o emaranhado de ligações entre diferentes países gera, por um lado, a confirmação do interesse da integração na região. Entretanto, tal situação dá também margem a questionamentos quanto à real intenção e eficácia das instituições regionais envolvendo países desse subcontinente, assim como quanto a seus múltiplos e contraditórios efeitos, inclusive em matéria de política comercial internacional.

Este intrincado sistema que se conforma configura o conceito de "spaghetti bowl" apresentado por Bhagwati $(2002)^{6}$, ou seja, resulta em uma multiplicidade de relações geradas pela proliferação do regionalismo com diversas sobreposições.

O spaghetti bowl da integração sul-americana, de acordo com as instituições regionais já apresentadas, está, neste momento, configurado conforme representação gráfica abaixo, que traduz a complexidade do emaranhado de relações entre os países, além de ilustrar o fato de alguns países fazerem parte simultaneamente de vários acordos regionais, incorrendo em diversas sobreposições. Mais grave, porém, não é a mera sobreposição, e sim o comprometimento de alguns países com blocos de posicionamentos divergentes.

\footnotetext{
${ }^{6}$ Nas palavras do autor, spaghetti bowl é conceituado como: a messy maze of preferences as PTAs formed between two countries, with each having bilaterals with other and different countries, the latter in turn bonding with yet others, each in turn having different rules of origin for different sectors, and so on. I called it a spaghetti bowl because it is an unruly mass of crisscrossing strings that, in any case, is beyond my capabilities.
} 


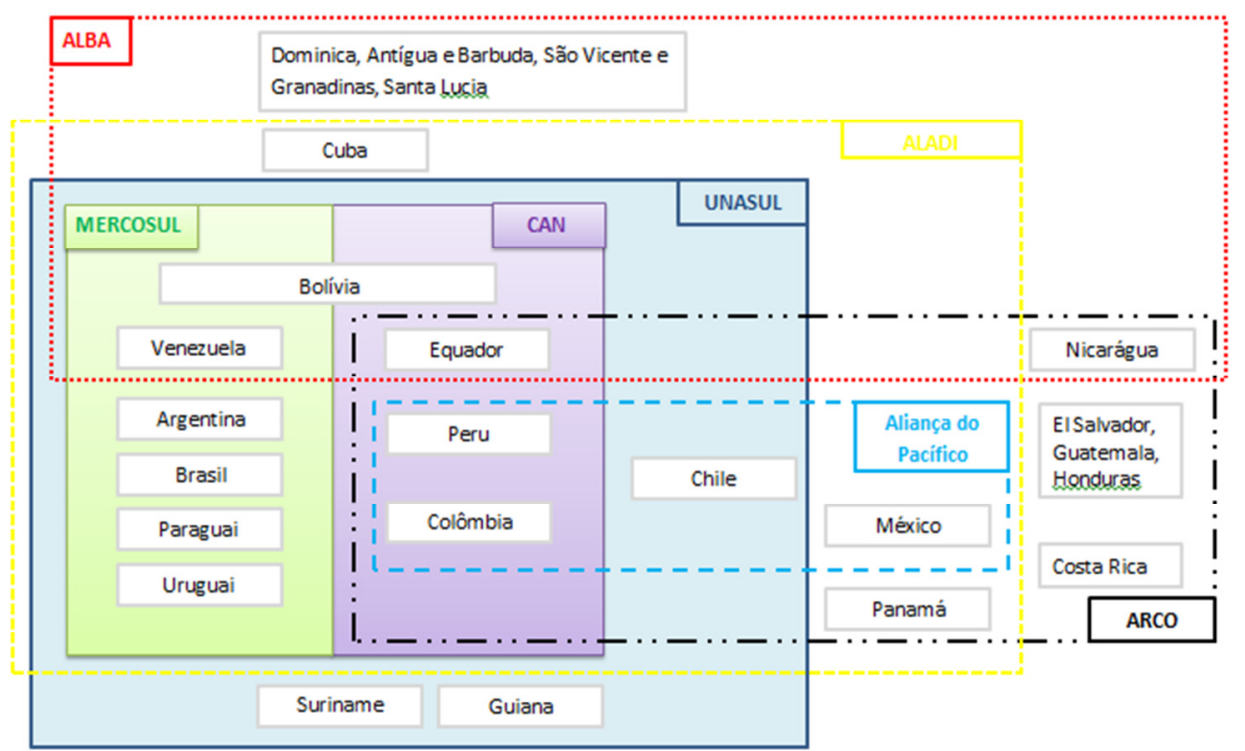

Figura 1: Spaghetti bowl formado pelas instituições regionais com presença na América do Sul. Elaboração da autora.

Um dos exemplos mais complexos no contexto ilustrado acima é o caso do Equador, que tem participação na CAN, na UNASUL, na ALADI, no ARCO e na ALBA. Diante de uma situação de tanta contradição como esta, questiona-se se é possível depreender que o país não tem um claro posicionamento ideológico? Ou mesmo, se a falta de efetividade das instituições que compõem este spaghetti bowl resultante das várias ações de integração na América do Sul pode ser responsável por gerar uma estratégia de participação em diversos organismos por interesses meramente políticos? Neste sentido, Portales (2013) também levanta alguns questionamentos:

\begin{abstract}
A prática de processos sobrepostos, superpostos ou paralelos de interação regional conduziu, no melhor dos casos, a intensas trocas de informação sobre políticas mais do que a sua coordenação e harmonização. Tal situação nos leva a refletir sobre para onde se move o centro de gravidade desses processos. Haveria uma vontade de integração ou trata-se apenas de manter mecanismos de associação política para atenuar e manejar as diferenças nos âmbitos regionais e sub-regionais? Nenhum dos mecanismos examinados conta com elementos de supranacionalidade que permita ao menos um trabalho nos Estados para produzir encadeamentos de compromissos e o fortalecimento de uma vontade comunitária. No entanto, há diferenças de grau entre as associações que carecem de qualquer elemento comum e as que são conduzidas por mecanismos pro tempore e aquelas em que uma Secretaria Geral poderia oferecer maior continuidade e certa visão coletiva. Contudo, num período de distanciamento de visões entre os atores regionais, mesmo essa capacidade se vê afetada. O encadeamento de interesses comuns pela via do aumento das áreas temáticas perde seu efeito ao diluir-se na repetição. (PORTALES, 2013, p. 223)
\end{abstract}

Malamud considera haver uma crise na integração regional como um todo e, entre as razões para tanto, está o fato de não existir uma definição clara do que se busca integrar (América Latina, América do Sul ou as Américas) ou de como fazê-lo e, além disso, são criadas novas instituições sem que se defina o que será feito com as previamente existentes, em um constante acréscimo de siglas e acrônimos (MALAMUD, 2012, p. 1). 
A integração direcionou-se à coordenação política, assim, pouco tem sido feito em uma área marcada pela fragmentação que impacta a América Latina e suas relações intraregionais. (MALAMUD, 2012, p. 2). E é nesse contexto voltado às questões políticas da UNASUL que ressurge o foco no comércio internacional, por meio das ações integracionistas dirigidas ao Pacífico, sendo que essas têm sua atuação baseada em acordos preferenciais bilaterais. Consequentemente, passam a ser intensamente explorados os acordos bilaterais, em especial por Colômbia e Peru, além do Chile que já vinha utilizando este tipo de negociações para a ampliação do seu mercado, inflando ainda mais o spaghetti bowl das relações dos países da América do Sul intra e extra-zona.

De acordo com Portales (2013), essa proliferação de organismos regionais não só produziu confusão de competências, mas definições distintas e contraditórias de como abordar importantes temas.

\begin{abstract}
Desacordos sobre modelos econômicos e sobre sua inserção internacional afetaram os processos de integração comercial; divergências sobre a democracia e os direitos humanos começaram a afetar os mecanismos existentes e levaram à procura, ainda que incipiente, de canais alternativos; os temas políticos internacionais e de segurança também foram deslocados para múltiplos cenários; e a proliferação de referências criou mecanismos paralelos de cooperação em políticas públicas. De como se vão articulando e resolvendo essas diferenças depende o destino do regionalismo nas Américas e na ALC. Tem especial importância a atenção às políticas externas desses países e seu efeito nas políticas multilaterais e de integração regional. (PORTALES, 2013, p. 219-220)
\end{abstract}

Para fins desta pesquisa e frente à conjuntura de sobreposições dos temas tratados delas diversas ações regionalistas, destaca-se primeiramente que muitas dessas ações estão relacionadas com o comércio internacional e consequentemente influenciam as políticas de comércio internacional adotadas pelos países membros.

Verifica-se, assim, que as ações regionais mais relevantes na influência de políticas comerciais internacionais no continente sul-americano são primeiramente as que estão permeadas por forte ideologia, como a ALBA, bem como as que vinculam a atuação de seus membros como o MERCOSUL. Ainda, o ponto que acaba mais se destacando neste cenário, é mesmo as contradições geradas pela participação em tantas ações de integração simultaneamente, como fazem alguns dos países da região. 


\subsection{América do Sul dividida em três vertentes de política de comércio internacional}

Diante de um subcontinente inundado por distintas manifestações de regionalismo, sendo algumas delas dotadas de posicionamentos contraditórios e temas sobrepostos, apesar de blocos antagônicos conterem frequentemente os mesmos membros, é natural que existam fragmentações. No que diz respeito ao posicionamento referente ao comércio internacional, tema abordado de maneira intensa por muitos dos blocos de integração ou de cooperação identificados na América do Sul, tal fragmentação apresenta-se com três perfis principais e divergentes entre si, sendo um deles mais aberto ao comércio, outro intermediário com foco regional e um terceiro de visão nacionalista com tendências a isolar-se, consoante detalhes destes perfis mais à diante.

A crise financeira global datada de 2008, com graves consequências econômicas difusas através do mundo, funcionou como incentivo para alterações de posicionamentos, em especial com relação às políticas de comércio internacional, na busca pela recuperação de uma fatia do mercado perdido, com o objetivo de alcançar um reestabelecimento econômico. Tal conjuntura parece ter influenciado profundamente alguns países sul-americanos e suas políticas.

É importante destacar que, historicamente, a América do Sul se trata de um subcontinente que foi fragmentado antes mesmo de seu nascimento, com a assinatura do Tratado de Tordesilhas, que o dividiu em duas partes, sob diferentes influências e esses reflexos, de certa forma, permaneceram impressos na região. "A América do Sul ficou, por praticamente cinco séculos de história, com a configuração política de um arquipélago, fragmentada em ilhas isoladas" (SIMÕES, 2012. p. 13), sem que houvesse uma relação próxima entre os países da região, fosse ela comercial ou política.

A relação extrativista que os colonizadores estabeleceram com as colônias na atual região da América do Sul também firmou características negativas para o seu desenvolvimento. O primeiro ponto é a relação exclusiva com Portugal ou Espanha, fazendo com que a região fosse voltada para fora e não para dentro dela mesma. Além disso, o fato de o ponto central ser o extrativismo, e não o desenvolvimento local, deixa marcas até os dias atuais, pois a região historicamente exportadora de produtos como minérios e commodities para abastecer os colonizadores, definiu assim seu perfil exportador, permanecendo com produtos de baixo valor agregado como base de sua pauta de exportação. 
É nesse contexto que nasce o subcontinente chamado América do Sul e, tendo em vista este passado, pode-se considerar que foram grandes os esforços em termos de integração regional. No entanto, não foram ações organizadas, sendo notável a falta de unidade ou mesmo de coordenação entre as nações sul-americanas, bem como entre os diversos acordos regionais de comércio vigentes em seu território.

Um período de grandes mudanças foi o pós Segunda Guerra, no qual o há uma alteração na distribuição de poder, até àquele momento localizado na Europa, para uma nova ordem, na qual impera a bipolaridade entre Leste e Oeste, representada, de um lado, pelos Estados Unidos, com sua visão ocidental capitalista, e de outro, pela ex-União Soviética, defensora do socialismo. É neste período, a partir da metade do século XX, mais especificamente nos anos 1960, que surgem importantes impulsos integracionistas na região da América do Sul. Na realidade, eles nascem dentro de um contexto um pouco mais amplo, abrangendo a América Latina como um todo, depois se tornam mais localizados e, recentemente, se ampliam novamente, até mesmo para fora do continente.

Outro momento claro de alteração da ordem internacional é o fim do período bipolar, no final da década de 1980 e início da década de 1990, quando o mundo deixa de ser dividido em Ocidente e Oriente, e passa a ser dividido entre Norte e Sul, sob a hegemonia americana. Mais uma mudança que gera reflexos nos interesses e posicionamentos dos países em geral, incluindo os sul-americanos, com efeitos em suas ações de política de comércio internacional, que se abriram às exportações. Conforme Giordano e Devlin (2011):

\begin{abstract}
Nesse marco transformaram-se e foram revitalizados mecanismos de integração comercial, emergindo um "novo regionalismo" ou regionalismo aberto, que não mais visa criar um mercado ampliado com barreiras ao exterior, mas integrar-se para obter vantagens competitivas num processo aberto ao mercado mundial (GIORDANO e DEVLIN apud PORTALES, 2013, p.209).
\end{abstract}

O momento atual, no qual ainda se identificam os efeitos da crise financeira iniciada em 2008, aliado a ascensão da China como potência econômica e destaque de outras potências regionais, bem como os questionamentos ao sistema multilateral, trazem incertezas quanto ao futuro da ordem mundial e os efeitos que a mesma poderá ter nos países da América do Sul, nas suas associações e nas políticas comerciais internacionais dos países desta sub-região.

Ademais, a multiplicidade de acordos regionais de integração que envolve os países da América do Sul, suas sobreposições, a falta de coordenação entre eles e o emaranhado de relações que se tem como resultado demonstram a fragilidade do conceito da região sulamericana.

O conceito de região pode aparecer só como um âmbito de ação preferencial ou como um espaço que contém atores relacionados num sistema distinguível de outros sistemas. Para que uma região chegue a ter significação política, ela precisa 
desenvolver uma capacidade de ação comum que se incrementará uma vez que haja propósitos coincidentes, mecanismos efetivos para formular e implementar políticas comuns e finalmente vínculos que permitam sua transformação em uma unidade maior, num processo de integração (PORTALES, 2013, p. 228).

Apesar das diversas tentativas integracionistas sul-americanas, como a ALADI, que substituiu a ALALC em 1980, o Pacto Andino que posteriormente se transformou em CAN, o próprio MERCOSUL, a ALBA, além de ações mais recentes como a UNASUL, abrangendo praticamente todo o subcontinente, e as ações voltadas para o Oceano Pacífico como o ARCO, a Aliança do Pacífico e o TPP, não se identifica entre elas ação comum, em especial quando se fala em política de comércio internacional. Segundo, RUIZ (2010), se parte da premissa de que se está produzindo uma fragmentação do hemisfério em três eixos que propõem modelos econômicos bastante diferentes para o projeto regional. Há, portanto, três posicionamentos principais e divergentes presentes na América do Sul e, exatamente neste sentido, Simões (2012) escreve que:

Há o bloco dos neoliberais, que formou recentemente o Arco do Pacífico e que inclui Chile, Peru e Colômbia. Há o bloco da ALBA, a Venezuela, o Equador e a Bolívia, países que buscam outra visão, com base na cooperação, uma visão muito mais idealista e menos comercial. Por fim, há o modelo brasileiro de economia aberta, com inclusão social e com componente estatal bastante acentuado e que, a meu ver, tende a ser ainda mais acentuado como fator indutor do desenvolvimento (SIMÕES, 2012. p. 68).

A classificação de Simões citada acima em neoliberais, bloco da ALBA e modelo brasileiro, corrobora com as três diferentes visões de política de comércio internacional trazidas pelo presente estudo identificadas na América do Sul. As denominações, porém, serão feitas de acordo com sua a atuação em política externa voltada ao comércio, a qual se convencionou chamar de política de comércio internacional, com as três vertentes: Regionalmultilateralista, Liberal-bilateralista, Extremo-nacionalista.

Ao Brasil, juntam-se os demais países do MERCOSUL, classificados no grupo que conforma uma visão Regional-multilateralista, em um modelo que se iniciou com a própria criação deste bloco econômico, no qual se busca ampliar o mercado recorrendo a negociações sob um espectro multilateralista. Esta seria uma vertente central entre duas outras, que são a visão Extremo-nacionalista e a visão Liberal-bilateralista, consideradas aqui como antagônicas.

No grupo dos neoliberais, que será referido como posicionamento Liberal-bilateralista estão Chile, representante de um perfil de política de comércio internacional totalmente independente, focando em tratados bilaterais de livre comércio para ampliar a liberalização comercial, além de Peru e Colômbia. Esses, por sua vez, são membros do bloco econômico Comunidade Andina de Nações juntamente com Bolívia e Equador, porém no contexto atual 
não podemos classificá-los no mesmo grupo tendo em vista a discrepância com relação às suas formas de atuação internacional. Enquanto Peru e Colômbia são democracias neoliberais, que se enquadram juntamente com o Chile no grupo Liberal-bilateralista e apresentam dados macroeconômicos bastante consistentes configurando as economias mais abertas da subregião; Bolívia e Equador apresentam características próximas da Venezuela, formando esses três últimos o grupo de visão Extremo-nacionalista.

Esses países são vistos com desconfiança no ambiente internacional tendo em consideração seus governos esquerdistas extremos que, em histórico recente, promoveram ações de desapropriações de patrimônio de empresas estrangeiras, fechamento de mercado, entre outras medidas que resultam no seu afastamento cada vez em maior grau do mercado internacional como um todo.

Na literatura aparece reiteradamente esta cisão em três vertentes distintas na América do Sul, às vezes com alguns pontos divergentes na classificação de um país ou outro dentro dessas vertentes, ou na abrangência de sua classificação, incluindo toda a extensão da América Latina, ou mesmo todo o continente americano. Por sua vez, Katz traz essa classificação em texto sobre Governos e Regimes na América Latina na forma de três tipos de governo, sendo que os i) conservadores são considerados neoliberais, pro norte-americanos, repressivos e opostos a melhoras sociais; os ii) centro-esquerdistas, aqueles que mantém uma relação ambígua com os Estados Unidos, que arbitram entre o empresariado e toleram as conquistas democráticas; e os iii) nacionalistas radicais, os estadistas, que combatem o imperialismo e a burguesia local, mas oscilam entre o novo-desenvolvimentismo e a redistribuição de renda (KATZ, 2012). Trata-se de uma classificação bastante genérica e quase estereotipada, ao traçar características tão definitivas e antagônicas entre os grupos, porém, que também corroboram com a ideia de fragmentação e discrepância ideológica entre países da região.

Ruiz (2010) igualmente identifica três eixos distintos que propõe modelos econômicos bastante diferentes no continente americano. Muito embora o autor aborde o continente inteiro, as definições do três posicionamentos é exatamente compatível com a classificação proposta acima. O autor nomeia como i) "Eixo do Regionalismo Aberto - TLC" a visão que abordamos sob a expressão Liberal-Bilateralista, incluindo neste grupo o NAFTA ${ }^{7}$, a América Central, parte do Caribe e alguns países sul-americanos que firmaram TLC - chamados FTAs para fins deste estudo - com os Estados Unidos. Este eixo, segundo o autor, tem um enfoque

\footnotetext{
${ }^{7}$ Tratado Norte-Americano de Livre Comércio, em inglês North American Free Trade Agreement, - NAFTA, que também pode ser referido como TLCAN do espanhol: Tratado de Libre Comercio de América del Norte.
} 
próprio do "novo regionalismo internacional", centrado exclusivamente no comércio e nos temas com ele relacionados.

Apesar de referido pelo autor como "novo regionalismo internacional" questiona-se se é realmente nova esta posição, ou se o que ocorre nestes países que buscam firmar FTAs com parceiros variados não é, na realidade, uma retomada das negociações bilaterais, como era antes do domínio da multilateralidade.

Em contraposição a este modelo aberto de integração, Ruiz (2010) traz duas visões, um a qual se refere como ii) "Eixo Revisionista", representada pelo MERCOSUL, e outra chamada de iii) "Eixo Anti-sistêmico", representado pela ALBA. Nesta divisão utilizada pelo autor, o "Eixo Revisionista", o qual é aqui abordado como Regional-Multilateralista integrado pelos países do MERCOSUL, não obstante tenha nascido sob a lógica da integração e da abertura comercial, converteu-se em um processo com uma dimensão social e produtiva, tendência confirmada pela UNASUL, que exerce uma função mais política e social que econômica. Enquanto o "Eixo Anti-sistêmico", que foi aqui batizado como ExtremoNacionalista traz uma proposta de integração que se descreve como não capitalista, propondo uma ruptura com o regionalismo aberto na busca de uma integração baseada na cooperação.

Ao tratar das relações dos países da América Latina em geral com os Estados Unidos, Russel e Tokatlian estabelecem que, em resumo, a década dos noventa foi a etapa de acomodação em blocos e de diferentes graus de relação com Washington. A ampliação da democracia e o mercado tiveram ampla aceitação na América Latina sob a forma de extensão das áreas de livre comércio e da democracia liberal. (RUSSEL e TOKATLIAN, 2009, p. 213). A utilização da palavra liberal neste ponto, não conforma automaticamente apenas os países que classificamos atualmente como de atuação Liberal-Bilateralista, pois na referida década, a abertura dos mercados e privatizações foi o padrão dominante nos países da América do Sul em geral.

Os autores citados acima seguem introduzindo, então, o início da visão a qual nos referimos como Extremo-Nacionalista, ao tratar que no final da década de noventa, profundas mudanças na política venezuelana mostraram a vontade de seu novo líder, Hugo Chávez, de ressuscitar uma estratégia de oposição aos Estado Unidos, despontando a diversidade regional. E, com relação à distinção econômico-comercial, destacam que há um contraste entre a América do Sul do Pacífico, com Chile, Colômbia e Peru que se aproximam cada vez mais dos EUA; e a América do Sul do Atlântico, na qual inclui Venezuela, Brasil e Argentina, que foram contra a ALCA e adotam estratégia econômica com forte participação do Estado. Neste ponto, diferindo da classificação adotada neste estudo, já que aqui se separa a atuação 
comercial internacional de Brasil e MERCOSUL, que realmente tem certa participação do Estado, mas que evoluíram em seu grau de abertura de maneira diversa dos países de posição Extremo-Nacionalista que incluem Venezuela, Bolívia e Equador.

Portales (2013) também vislumbra três vertentes diferentes no continente sulamericano quando trata do futuro do multilateralismo regional, que a seu ver é determinado pelas políticas de desenvolvimento. Para ele, alguns países seguem avançando na abertura de mercados e na procura de novas disciplinas para organizar o intercâmbio e a concorrência num mundo globalizado, como é o caso da Aliança do Pacífico; outros optam por variar as negociações com os principais mercados mundiais, esperando reformas mais abrangentes das economias mais desenvolvidas e evitando compromissos que possam limitar o próprio desenvolvimento, descrição para a qual cita como representante o MERCOSUL, em especial o Brasil; e há ainda uma terceira vertente de Estados críticos da globalização com modelos de forte presença estatal e alheios à ideia de livre-comércio, visão compartilhada pelos países da ALBA (PORTALES, 2013, p. 228).

Este grupo, representado pela ALBA, por sua vez, embora tenha uma forte carga ideológica e tenha ganhado adeptos com a crescente de governos de esquerda eleitos em países sul-americanos, não deve representar a tendência de política de comércio internacional deste subcontinente, pois tal visão não é compatível com um mundo globalizado e interdependente, bem como resulta em isolamento e perda de espaço no mercado internacional. Por sua vez, o grupo Liberal-bilateralista apresenta posicionamento inverso, e sua política de liberalização mostra-se cada vez mais forte na região. Será a retomada desta visão, após período de predominância da visão Regional-multilateralista na América do Sul, a tendência de política de comércio internacional para a região? Para que se chegue a uma conclusão acerca desde ponto, faz-se necessário compreender mais a fundo cada um dos três posicionamentos conforme classificado acima.

\subsubsection{A visão Liberal-Bilateralista e seus representantes}

A atuação bilateralista não se trata exatamente de uma novidade quando se aborda as relações internacionais dos Estados, em especial tratando-se de política comercial. O bilateralismo, de fato, antecede a existência do multilateralismo e, até a II Guerra Mundial, era a forma de atuação na qual os Estados se pautavam na esfera internacional. 
Nas relações comerciais bilaterais, os dois países ${ }^{8}$ envolvidos concedem, uns aos outros, preferências que objetivam fomentar os fluxos de comércio entre si. Como resultado, há uma liberalização do comércio, porém, a mesma está limitada aos países participantes, que formalizam suas intenções e compromissos mútuos por meio dos chamados acordos bilaterais.

Após a II Guerra, o bilateralismo perdeu força em razão do nascimento de um novo sistema internacional baseado no multilateralismo, implementado pelo GATT, em 1947, que posteriormente se transformou em Organização Mundial do Comércio - OMC. Com o estabelecimento deste "Acordo Geral de Tarifas e Comércio", o foco passa a ser o novo sistema que se forma, visando à liberalização do comércio com abrangência global, na busca do objetivo final de crescimento econômico e desenvolvimento.

É por esta razão que se pode afirmar que a negociação de preferências por meio de acordos bilaterais se trata de uma retomada, pois após a criação e evolução do sistema multilateral, a mesma deixou de ser predominante, inclusive para os países classificados como Liberais-bilateralistas, que voltaram sua atuação ao multilateralismo, e só recentemente se redirecionam à formação de acordos preferenciais de comércio bilaterais. Não se pode dizer, no entanto, que o bilateralismo e o multilateralismo são incompatíveis, eles podem sim coexistir, principalmente em sendo as negociações bilaterais uma forma de ampliar a liberalização de mercados, e estando os tratados em consonância com as regras do sistema multilateral de comércio. Confirmando esta abordagem, Ruiz (2010) afirma que o regionalismo aberto, posto que seu objetivo é promover um espaço comercial preferencial, não se dá às custas do sistema multilateral de comércio; pelo contrário, as preferências regionais se concebem como um passo prévio na direção de uma maior abertura global (RUIZ, 2010, p. 45).

É o que ocorre na prática com Chile, país de atuação totalmente independente e focada em acordos de livre comércio bilaterais, que, por outro lado, é também membro da Organização Mundial do Comércio - OMC que estabelece o sistema multilateral e com seus diversos acordos bilaterais abrange uma gama tão extensa de parceiros internacionais que pode ser interpretado como um caminho para a liberalização em abrangência global. Pode ser considerado, ainda, um caminho mais fácil, pois alcançar um acordo entre dois países é mais factível que alcançar um acordo entre vários, como comprovado pelos impasses vividos pela OMC na falta de conclusão da Rodada Doha.

\footnotetext{
${ }^{8}$ Atualmente um acordo bilateral não necessariamente se restringe a países, havendo a possibilidade de as partes serem blocos regionais ou organizações internacionais, por exemplo.
} 
Ao mesmo tempo, optar por negociações bilaterais deixa os países mais vulneráveis quando a relação se dá com Estado de maior poder no cenário internacional e consequente maior poder de barganha nas negociações. De fato, a assinatura de acordos preferenciais de comércio bilaterais estabelecendo relações no eixo Norte-Sul, cujas assimetria são evidentes, tem se multiplicado. Mesmo enfrentando assimetrias, essa forma de negociação de tratados internacionais de comércio foi a opção escolhida por países sul-americanos com visão liberalbilateralista para a liberalização recíproca de seus mercados com potências como China, Estados Unidos e União Europeia.

Entre os países com visão Liberal-bilateralista, há algumas diferenças que merecem ser mencionadas e, embora o grupo de países divida-se em sub-perfis com características específicas, nota-se como ponto de convergência uma clara influência americana, sendo que os três países representantes deste perfil de política de comércio internacional na América do Sul dispõem de acordos de livre comércio com os Estados Unidos. Tem-se, por um lado, o Chile, com sua forma de atuação definida acima, e por outro Peru e Colômbia, que adotaram esta visão mais recentemente. Os três Estados foram parte do Pacto Andino, que posteriormente se transformou em Comunidade Andina, sendo que Chile retirou-se do referido bloco em 1979, já dando sinais de sua estratégia de atuação independente no campo internacional, passando somente a membro observador de tal instituição e, posteriormente a membro associado por meio da UNASUL, seu status atual.

Peru e Colômbia permanecem até os dias de hoje na Comunidade Andina como membros e ao visualizar seus históricos de acordos comerciais, fica claro que houve uma mudança recente na abordagem internacional. Anteriormente, as negociações com este teor ocorriam em nome do bloco e, mais recentemente, o enfoque é alterado para negociações bilaterais, como se verá detalhadamente na análise das tendências marcadas pelos Acordos Preferenciais de Comércio (PTAs). Essas recentes alterações na visão de política de comércio internacional de Peru e Colômbia, aproximando-os da já consolidada visão chilena, levam à construção da hipótese de que há uma retomada da visão Liberal-Bilateralista, e que esta pode ser a tendência em política comercial para a região da América do Sul.

No objetivo de expandir seus mercados, esses países vêm firmando acordos bilaterais com diversas nações espalhadas pelo mundo. Neste sentido, não há um enfoque regional, mas global. Assim, os ditos países neoliberais sul-americanos estão abertos a negociações com outras regiões e é possível notar tal fato em razão de negociações de acordos recentes, nos quais sua atenção e interesse comercial volta-se ao Oceano Pacífico, por meio do ARCO, da Aliança do Pacífico e do Acordo de Associação Transpacífico. 
Os acordos firmados no âmbito da Aliança do Pacífico não substituem acordos econômicos, de integração comercial e acordos bilaterais ou multilaterais entre as partes, sendo que a forma prevista para a participação de observadores e novos Estados Partes exige que se firme um acordo de livre comércio com cada uma das partes. Enfatizando-se, por consequência, o bilateralismo como forma de negociação, mesmo dentro de ação regional com características de multilateralidade em vista da participação de diversos Estados.

Marcando um perfil comum entre os três Estados sul-americanos classificados como Liberais-bilateralistas juntamente com México, Portales (2013) versa que:

Finalmente, Chile, Colômbia, Peru e México acordaram em junho de 2012 em Paranal, no Chile, a Aliança do Pacífico (AP). Esses países têm seguido políticas econômicas com alto grau de coincidências e têm acordos de livre-comércio entre eles, com os Estados Unidos e com a UE, e alguns também com a China e o Japão. A AP representa $35 \%$ do PIB e mais de 50\% do comércio exterior da ALC. São os países mais abertos ao comércio internacional na região. Três são membros da Cooperação Econômica da Ásia-Pacífico (Apec, na sigla em inglês) - México, em 1993; Chile, em 1994; e Peru, em 1998 - e a Colômbia é candidata. As negociações em curso em 2013 para estabelecer uma área de livre-comércio comum da AP deveriam dar-lhe novo impulso, mas essa organização tem uma vocação de vinculação transregional: seguindo uma proposta de 2002, Chile, Singapura, Nova Zelândia e Brunei assinaram um Acordo de Associação Econômica de caráter transpacífico, em 2006, que serve de base às negociações de um ambicioso Acordo Transpacífico (TPP) de que, com os quatro países originais, participam Estados Unidos, Austrália, Peru, Malásia e Vietnã e a que se incorporaram México, Canadá e Japão (grifo da autora). (PORTALES, 2013, p. 219).

O TPP reforça a influência dos Estados Unidos sobre os países liberais-bilateralistas da América do Sul, uma vez que esta é a maior potência econômica envolvida neste processo de integração, e o recurso a acordos plurilaterais confirma a hegemonia do país como líder deste grupo centrado no interesse comercial pela região Ásia-Pacífico.

Ainda com vistas a esta região, Natalino (2009) versa que a construção de um "Arco Pacífico" de estabilidade, democracia e segurança entre países americanos banhados pelo Pacífico, (oportunidade na qual o autor cita os países Chile, Peru, Panamá, México e Canadá) começou a ganhar impulso em 2007, em grande parte como contraposição à ALBA, liderada pela Venezuela. Há, deste modo, mais um autor contrapondo a visão liberal-bilateralista à ideologia extremo-nacionalista representada pela ALBA.

Conclui-se, com referência o grupo Liberal-Bilateralista, primeiramente, que apesar de os países estarem localizados na América do Sul, sua maior influência não advém desta subregião, mas dos Estados Unidos. Além disso, é clara a tendência à atuação de forma bilateral com vistas à liberalização no âmbito do comércio internacional, independente das novas iniciativas multilaterais das quais Chile, Colômbia e Peru estão dispostos a participar. Estas iniciativas comprovam a visão expansionista destes países, que buscam ampliar 
mundialmente seus mercados, sem um foco específico na América do Sul, pelo contrário, mostrando uma tendência de negociação com países de fora deste subcontinente, conforme comprovam mais adiante os PTAs dos quais são signatários.

\subsubsection{A visão Regional-Multilateralista e seus representantes}

O Brasil aparece como o representante principal da visão Regional-Multilateralista na América do Sul, sendo o multilateralismo a visão juridicamente compatível com o MERCOSUL. Em razão de haver evidente assimetria entre os países deste bloco que resulta do próprio tamanho de suas economias, é natural que ao falar do eixo RegionalMultilateralista dê-se mais ênfase a Brasil e Argentina, que aos sócios de pequeno porte Paraguai e Uruguai. Além disso, exclui-se Venezuela, membro mais recente do bloco, por questões ideológicas, visto que não apresenta o mesmo posicionamento em política de comércio internacional, bem como Bolívia, país em processo de adesão ao MERCOSUL, o qual acompanha a visão venezuelana.

Apesar de suas recentes movimentações com a suspensão do Paraguai e ingresso da Venezuela, o MERCOSUL alcançou uma união aduaneira imperfeita, e tem outros países da América do Sul como associados, representando uma significativa integração para a região e tendo influência sobre as políticas comerciais de seus membros, em especial por meio da unificação de suas tarifas de importação na TEC. As referidas movimentações recentes com a entrada de novos membros ao grupo, contudo, marcam a prevalência do interesse político sobre o interesse econômico-comercial, pois tais alterações são prenúncio de dificuldades futuras tendo em vista as diferentes posições que terão de conviver no interior do bloco, já que Venezuela é considerada como principal representante da visão Extremo-nacionalista.

O MERCOSUL é reiteradamente descrito na literatura como um modelo de integração aberta, ou regionalismo aberto $^{9}$, favorecendo, desta maneira, a liberalização do comércio intra-zona sem afetar a abertura ao resto do mundo. A crítica de Ruiz (2010), no entanto, vem no sentido de que este bloco nasceu como um modelo híbrido, pois ao mesmo tempo em que dispõe de elementos típicos do regionalismo aberto, carece de uma agenda de integração profunda.

\footnotetext{
${ }^{9}$ Termo já mencionado neste mesmo estudo em citações de LAFER; RUIZ; GIORDANO e DEVLIN.
} 
Os países do MERCOSUL não apresentam grandes contradições relacionadas às suas ações de integração, já que são membros deste bloco de integração econômica regional, que é perfeitamente compatível com sua participação na ALADI, âmbito no qual dispõem de alguns acordos e, por tratar a UNASUL de assuntos cunho político e afastar-se cada vez mais de questões específicas de comércio, resulta em não haver sobreposição dos temas tratados no escopo desta ação de integração.

Estes países têm como princípio buscar acordos na esfera multilateral, preterindo os tratados internacionais de negociação bilateral na busca da liberalização comercial, salvo algumas recentes tendências neste sentido que se verá ao analisar os acordos preferenciais de comércio. Embora almejem a liberalização do comércio de forma multilateral, a realidade mostra que tais países tem recorrido a medidas para proteger seus mercados, com maior ênfase a partir da crise mundial iniciada em 2008. No entanto, para que se mantenham em consonância com o sistema multilateral, os Estados sul-americanos representantes da vertente regionalista buscam fazer uso de medidas de defesa comercial compatíveis com a OMC.

Esta tendência marca os países multilateralistas, mas em especial o Brasil, cujos números oficiais relativos ao uso de medidas de defesa comercial são os mais altos do subcontinente, seguidos da Argentina, que também mostra recorrer a este tipo de medidas com mais frequência que os demais vizinhos sul-americanos.

Quadro 1 - Medidas de Defesa Comercial na América do Sul - 2009 a 2013

\begin{tabular}{|c|c|c|c|c|c|c|c|c|}
\hline \multirow{2}{*}{$\begin{array}{l}\text { América } \\
\text { do Sul }\end{array}$} & \multicolumn{3}{|c|}{ Antidumping } & \multicolumn{3}{|c|}{ Medidas Compensatórias } & \multicolumn{2}{|c|}{ Salvaguardas } \\
\hline & Iniciada & Vigente & Retirada & Iniciada & Vigente & Retirada & Iniciada & Vigente \\
\hline Argentina & 72 & 49 & 33 & & & & & \\
\hline Brasil & 126 & 50 & 47 & 4 & & 1 & 1 & \\
\hline Chile & 8 & 3 & 4 & & & & 4 & 1 \\
\hline Colômbia & 22 & 5 & 16 & & & & 4 & \\
\hline Equador & 2 & & 2 & & & & 1 & 1 \\
\hline Paraguai & & & 1 & & & & & \\
\hline Peru & 6 & 4 & 29 & 3 & 2 & 1 & 1 & \\
\hline Uruguai & 1 & 1 & & & & & & \\
\hline Venezuela & & & 10 & & & 1 & & \\
\hline Total & $\underline{237}$ & $\underline{112}$ & $\underline{142}$ & $\underline{7}$ & $\underline{2}$ & $\underline{\mathbf{3}}$ & $\underline{11}$ & $\underline{2}$ \\
\hline
\end{tabular}

Fonte: OMC

Medidas de defesa comercial devem ser usadas em caráter de exceção, a fim de neutralizar as distorções de mercado; no entanto, por meio da análise do quadro acima, percebe-se que Brasil e Argentina recorrem com frequência a este tipo de medida, em especial ao antidumping como forma de compensar as distorções do mercado. O período ao qual o 
quadro se refere está compreendido entre 2009-2013, período de cinco anos imediatamente após o início da crise global de 2008.

Os dados demonstram que dentre as 237 investigações de antidumping iniciadas na América do Sul no período, 198 são pertencentes conjuntamente ao Brasil e a Argentina, bem como dentre as 112 sobretaxas vigentes neste período, 99 são aplicadas por estes dois países representantes da vertente de política de comércio internacional regional-multilateralista.

\subsubsection{A visão Extremo-nacionalista e seus representantes}

A visão Extremo-nacionalista não se trata exatamente de uma visão voltada à esfera internacional, trata-se mais de uma visão nacionalista que repercute na relação desses países com outros Estados. Os países que representam este posicionamento são Venezuela, Equador e Bolívia, que apresentam características diferentes e são membros de alguns blocos regionais distintos na América do Sul, porém todos participantes da ALBA. O que os faz serem classificados conjuntamente é a situação atual na qual se encontram, bem como suas recentes ações de políticas comerciais, com uma clara tendência de fechamento de mercado, mas principalmente sua ideologia de política de comércio internacional.

Enquanto Equador e Bolívia permanecem como membros da já citada Comunidade Andina, a Venezuela deixou a CAN em 2006 e atualmente é parte do MERCOSUL. Desse fato emana imediatamente o questionamento de porque países pertencentes a blocos econômicos regionais diversos estariam no mesmo grupo quando se aborda o tema de políticas comerciais.

Ocorre que, conforme visto, as ações integracionistas regionais podem exercer mais ou menos influência nas políticas comerciais de seus membros, e o que se identifica entre estes países é que, mais que um alinhamento com os respectivos blocos econômicos dos quais são parte, seu posicionamento em política comercial externa está coordenado com a ALBA e sua clara oposição ao liberalismo.

A Aliança Bolivariana para os Povos da Nossa América - Tratado de Comércio dos Povos, representada pela sigla ALBA-TCP, conforme já descrito, não é um bloco econômico regional, mas uma plataforma de integração para os países da América Latina e do Caribe, com foco na cooperação. A ALBA tem forte influência de doutrinas de esquerda, o que pode ser identificado desde sua criação, que ocorreu em 2006 em Cuba, na cidade de Havana, em uma reunião entre Fidel Castro, então presidente do país, e o presidente da Venezuela, Hugo 
Chávez. A ALBA define-se como uma forma de integração e união da América Latina e do Caribe, com base em um modelo de desenvolvimento independente, com destaque para a complementaridade regional que permita promover o desenvolvimento de todos e fortalecer a cooperação através do respeito mútuo e da solidariedade.

Os países que atualmente compõem a ALBA são Venezuela, Cuba, Bolívia, Nicarágua, Dominica, Antígua e Barbuda, Equador e São Vicente e Granadinas. A Bolívia foi o terceiro país membro, aderindo a ALBA em 2006 e o Equador tem um vínculo mais recente com esta plataforma, iniciado em meados de 2009. A grande influência da ALBA na política comercial destes países reside no fato de não se tratar de uma tentativa de integração voltada ao livre comércio, pelo contrário, é pautada pela cooperação, porém com uma atuação independente e, declaradamente em contraposição ao poder hegemônico americano e ao liberalismo.

\begin{abstract}
A Alba pretende explicitamente construir uma alternativa anti-"integração neoliberal"; está contra as políticas protecionistas e os subsídios dos países industrializados e postula um tratamento especial e diferenciado para seus associados; opõe-se às políticas de ajuste estrutural; favorece a integração latinoamericana com uma agenda definida pelos Estados. Elemento-chave para construir essa aliança tem sido a política de créditos para o abastecimento de petróleo ao Caribe (Petrocaribe), vinculada a um fundo Alba-Caribe, de 2005, e a um Tratado Energético Alba, de 2007. Criaram-se ademais projetos na área das comunicações e mecanismos financeiros e seus membros adotaram posições comuns em política externa e nas organizações internacionais (Altmann Borbon, 2011, apud PORTALES).
\end{abstract}

Outra característica marcante com referência a esta vertente é que são países voltados para a América Latina, e sua liberalização comercial, embora limitada, também tem esta região como foco, em contraposição ao perfil de países liberais, os quais se voltam para novas oportunidades de associações com países de fora da região.

Os três países da América do Sul tidos como representantes da visão Extremonacionalista são países com governos baseados na doutrina esquerdista e com ações concretas que confirmam que suas políticas são opostas ao livre comércio, como a onda de nacionalizações de empresas estrangeiras, em especial aquelas relacionadas ao ramo energético. Tal evidência justifica não só o nome dado a este grupo de países, mas evidencia claramente o extremo-nacionalismo destes países.

A nacionalização de empresas é uma forma encontrada para a ampliação do protagonismo estatal na economia de Bolívia, Equador, e Venezuela (e Argentina devido a algumas ações pontuais, embora não enquadrada neste eixo). Esses três países, rescindiram a adesão ao International Centre for Settlement of Investment Disputes - ICSID, convenção multilateral que fornece a arbitragem de disputas entre investidores e Estados (LIMA, 2013), resultando em ainda mais insegurança jurídica para possíveis investidores externos e 
consequentemente os afastando desses países como destinos de investimento, confirmado o isolamento e o fechamento de mercado.

Com frequência as políticas nacionalistas sul-americanas de expropriação de empresas privadas incidem em companhias privatizadas na década de 1990, quando se recorreu indiscriminadamente às privatizações. Dentre as justificativas comuns apresentadas por esses governos estão: a necessidade pública, a ausência de investimentos por parte dos empresários, o aumento da capacidade exportadora nacional, e ingressos fiscais para políticas sociais, como se questões sociais pregadas pelos governantes populistas pudessem justificar quaisquer medidas extremas como é o caso das expropriações. Busca-se, assim, o populismo, porém, como resultado, estes governos afastam-se da democracia.

Entre as ações de nacionalização promovidas pelos países identificados neste posicionamento estão a nacionalização pela Venezuela de ativos das companhias petrolíferas norte-americanas Exxon Mobil, Chevron, e Conoco-Philips, e das europeias Total France, British Petroleum, e estatal norueguesa ASA. Além da área energética, as expropriações venezuelanas atingiram também área de telecomunicações, na Compañía Anónima Nacional de Teléfonos de Venezuela - CANTV, e no setor de eletricidade, a Servicio Eléctrico de Nueva Esparta y Electricidad de Caracas - SENECA (NEVES, 2010). Foi também nacionalizada a siderúrgica Temium entre outras nacionalizações ou alterações societárias compulsórias.

Por sua vez, a Bolívia recorreu a expropriações também no setor energético, incluindo nacionalização da indústria de gás do país em 2005. Em 2006, a brasileira Petrobrás, assim como outras petroleiras foram afetadas por nacionalizações por meio da empresa estatal YPFB - Yacimientos Petrolíferos Fiscales. O presidente ordenou, inclusive, a ocupação pelo Exército dos campos de produção, — seguida pela implantação da lei dos hidrocarbonetos em 2008, que introduziu uma taxa de royalty de $18 \%$ e uma taxa direta de $32 \%$. Foram também nacionalizadas em 2009 as petrolíferas CXhaco de propriedade da British Petroleum; em 2010, as empresas de energia Corani, Guaracachi, Valle Hermoso e Companhia de Energia Elétrica Cochabamba; e em 2012, a Transportadora de Eletricidad, gerida pela empresa Red Eléctrica Internacional, da Espanha. As movimentações neste sentido não foram distintas no Equador, com o aumento de taxas de exportação nos setores energéticos e renegociação de contratos com as companhias petrolíferas a fim de angariar recursos para programas sociais, além da introdução de uma nova legislação ao setor do petróleo, demonstrando o enfoque das nacionalizações nos setores energéticos (GRUGEL; RIGGIOROZZI, 2012, apud LIMA, 2013). 
Venezuela, Equador e Bolívia, protagonistas destas ações antidemocráticas, não surpreendentemente aparecem, portanto, nas últimas colocações no Ranking da Democracia dos países sul-americanos.

Ressalta-se que a Argentina, em grave crise econômica, embora não haja sido classificada no perfil extremo-nacionalista, promoveu recentemente ações com este cunho, expropriando em 2012 os ativos da YPF - Yacimientos Petrolíferos Fiscales de Argentina sob controle acionário da multinacional espanhola Repsol desde 1999.

Quadro 2 - Ranking Democracia
\begin{tabular}{r|r|l|}
\hline \multicolumn{2}{|l|}{ Países da América do Sul } \\
\hline 1 & Uruguai (17) \\
\hline 2 & Chile (35) \\
\hline 3 & Brasil (45) \\
\hline 4 & Argentina (51) \\
\hline 5 & Colômbia (55) \\
\hline 6 & Peru (56) \\
\hline 7 & Paraguai (62) \\
\hline 8 & Bolívia (84) \\
\hline 9 & Equador (89) \\
\hline 10 & Venezuela (97) \\
\hline
\end{tabular}

Fonte: The Economist - Quadro adaptado de LIMA, 2013

Questiona-se, ainda, como a Venezuela se enquadrará no MERCOSUL, bloco do qual faz parte desde 2012, em matéria de políticas comerciais, uma vez que os demais países deste bloco regional apresentam uma visão multilateralista, juridicamente compatível com a instituição, enquanto a Venezuela permanece com sua visão extremo-nacionalista. 


\section{Tendências de Política de Comércio Internacional na América do Sul}

A fim de comprovar o fortalecimento da posição liberal-bilateralista adotada por Chile, Colômbia e Peru - países que vem se utilizando de acordos de livre comércio - FTAs com formato de negociação bilateral e sem limitações a regiões específicas - foi realizado estudo detalhado dos Acordos Preferencias de Comércio notificados à OMC e constantes de sua base de dados. Buscou-se verificar empiricamente neste estudo a tendência da atuação em política de comércio internacional por esses instrumentos.

Enxergar de forma clara a realidade da região sul-americana com relação à utilização deste tipo de acordo, verificando a simetria dos países classificados em cada visão divergente de política de comércio internacional confere fundamento fático a esta pesquisa.

\subsection{Premissas Metodológicas}

Para traçar as tendências de Políticas de Comércio Internacional na América do Sul foi feita uma análise dos Acordos Preferenciais de Comércio tratados aqui pela sigla PTAs referente ao termo em inglês Preferential Trade Agreements, embora a OMC ainda faça uso do termo Regional Trade Agreements - RTAs, optou-se pelo termo preferenciais e não regionais, pois a abrangência geográfica também é objeto de análise tendencial.

Ao instituir mecanismos de transparência para notificações de acordos comerciais negociados entre países, blocos ou regiões, a OMC diferenciou RTAs ${ }^{10}$ e PTAs ${ }^{11}$, tratando estes últimos com o significado de esquemas preferenciais não recíprocos especialmente concedidos a países de menor desenvolvimento. No entanto, pelo seu significado literal e levando em consideração a amplitude dos acordos comerciais que vem sendo firmados, os quais extrapolam regiões, não pareceu cabível manter, para fins deste estudo, a denominação RTA usada pela instituição. Assim, adotou-se a denominação PTAs no significado rigoroso de seus termos, abrangendo, portanto, os acordos preferências de comércio negociados entre países ou organizações, sejam eles regionais, sub-regionais ou bilaterais.

Corroborando com a denominação escolhida, segundo Celli Junior (2012), como muitos dos acordos comerciais atuais são celebrados entre países de regiões geográficas

\footnotetext{
${ }^{10}$ Controlados pelo Transparency Mechanism for RTAs instituído pela Descisão do Conselho Geral de 14 de Dezembro de 2006.

${ }^{11}$ Controlados pelo Transparency Mechanism for PTAs instituído pela Descisão do Conselho Geral de 14 de Dezembro de 2010.
} 
distintas, apesar de o termo Acordos Comerciais Regionais (ou Regional Trade Agreements RTA) ainda ser utilizado pela OMC, o termo ideal a ser usado neste novo contexto deve ser Acordos Comerciais Preferenciais - ACP (CELLI JUNIOR, 2012, p 94).

A principal fonte de dados para esta pesquisa baseada nos PTAs é a própria OMC, que mantem um sistema de informação ${ }^{12}$ específico com este tipo de acordos. Os acordos analisados, por sua vez, são aqueles firmados por qualquer do dez países sul-americanos que são objeto deste estudo: Colômbia, Peru, Chile, Brasil, Argentina, Paraguai, Uruguai, Venezuela, Bolívia e Equador, seja de forma independente, ou por meio de blocos regionais dos quais são parte.

Não ficarão de fora, no entanto, para fins analíticos, Acordos Preferenciais de Comércio relacionados aos países em foco que por qualquer razão não estejam constantes na base de dados da OMC, bem como serão utilizados PTAs relativos a outros países e outras regiões para fins comparativos, assim como o histórico integracionista sul-americano.

Com referência à questão temporal, foi dada maior ênfase a um período que se inicia em 2009, após a crise financeira de 2008 - período no qual alguns países buscaram um reposicionamento no comércio internacional - até 2014. Busca-se identificar neste ínterim as tendências relacionadas às políticas de comércio internacional na América do Sul utilizandose, para tal fim, a base de dados da OMC sobre os PTAs. Contudo, o estudo não será estritamente limitado a este período, mas abrangerá todos os PTAs firmados pelos países objeto deste estudo, com o intuito de efetuar a comparação de períodos anteriores ao período enfatizado, com inclusão também dos PTAs datados de 2014.

Esta análise documental foi feita abrangendo as esferas temporal, geográfica, bem como relativa ao tipos de acordos, objetivando primeiramente comprovar que há uma homogeneidade na atuação dos países dentro de cada classificação, bem como demonstrar a hipótese de que há no contexto atual sul-americano uma tendência à visão LiberalBilateralista, com assinaturas de tratados bilaterais de livre comércio, trazendo questionamentos à posição multilateralista historicamente adotada pelo Brasil.

Há atualmente registrados perante a OMC cerca de duzentos e setenta PTAs vigentes, além de aproximadamente quarenta em processo de negociação, conectando diferentes partes do mundo, em um spaghetti bowl ainda mais complexo que quando considerada somente a área foco deste estudo.

\footnotetext{
${ }^{12}$ Regional Trade Agreements Information System (RTA-IS)
} 
A principal base de dados analisada que traz informações sobre os PTAs dos países objetos deste estudo foi dividida por países e na ordem de países de visão LiberalBilateralista, na sequência os países que seguem a vertente Regional-Multilateralista e depois os países de posicionamento Extremo-Nacionalista.

\subsection{Análise dos Acordos Preferenciais de Comércio - PTAs}

A primeira questão que se revela imediatamente ao olhar a base de dados em análise é a similitude dos perfis dos países agrupados conjuntamente em cada classificação de visão de política de comércio internacional. Enquanto Colômbia, Peru e Chile apresentam uma lista relativamente extensa de tratados preferenciais, cada um dos países representantes do MERCOSUL elenca somente entre quatro ou cinco tratados por eles firmados e em vigência. Já os países classificados como Extremo-nacionalistas dispõem somente de três tratados cada, havendo todos sido firmados na década de oitenta.

\subsubsection{Países de visão Liberal-bilateralista}

A tendência ao posicionamento Liberal-bilateralista fica claramente marcada na América do Sul a partir de 2009, quando Peru e Colômbia dão início à proliferação de acordos de livre comércio negociados em formato bilateral alcançando países de outras regiões.

Antes deste período, Colômbia tinha somente um tratado neste formato, firmado em 1995 com o México e, antes ainda, somente três acordos multilaterais da década de oitenta, sendo eles ALADI, CAN e GSTP ${ }^{13}$. A partir de 2009, Colômbia firmou seis FTAs, sendo somente um deles com país de dentro deste subcontinente, o Chile, e os outros cinco com países de fora da sub-região, incluindo: EUA, UE, Canadá, EFTA e países continentais da América Central - El Salvador, Guatemala e Honduras. Há ainda, um acordo em negociação com Costa Rica, já notificado a OMC por meio do mecanismo de transparência em status de anúncio antecipado ${ }^{14}$.

\footnotetext{
${ }^{13}$ GSTP, da sigla em inglês Global System of Trade Preferences, Sistema Global de Preferências Tarifárias entre Países em Desenvolvimento (SGPC), no âmbito da Conferência das Nações Unidas sobre Comércio e Desenvolvimento (UNCTAD).

${ }^{14}$ Early announcement - under negotiation
} 
Quadro 3 - PTAs Colômbia - Acordos em vigor

\begin{tabular}{|l|l|l|}
\hline \multicolumn{1}{|c|}{ Nome do Acordo (inglês) } & \multicolumn{1}{c|}{ Tipo } & \multicolumn{1}{c|}{ Entrada em vigor } \\
\hline EU - Colombia and Peru & FTA \& EIA & $01 / 03 / 2013$ \\
\hline US - Colombia & FTA \& EIA & $15 / 05 / 2012$ \\
\hline Canada - Colombia & FTA \& EIA & $15 / 08 / 2011$ \\
\hline EFTA - Colombia & FTA \& EIA & $01 / 07 / 2011$ \\
\hline $\begin{array}{l}\text { Colombia - Northern Triangle (El Salvador, } \\
\text { Guatemala, Honduras) }\end{array}$ & FTA \& EIA & $12 / 11 / 2009$ \\
\hline Chile - Colombia & FTA \& EIA & $08 / 05 / 2009$ \\
\hline Colombia - Mexico & FTA \& EIA & $01 / 01 / 1995$ \\
\hline $\begin{array}{l}\text { Global System of Trade Preferences among } \\
\text { Developing Countries (GSTP) }\end{array}$ & PSA & $19 / 04 / 1989$ \\
\hline Andean Community (CAN) & CU & $25 / 05 / 1988$ \\
\hline Latin American Integration Association (LAIA) & PSA & $18 / 03 / 1981$ \\
\hline
\end{tabular}

Fonte: RTA-IS / OMC

Destaca-se que o único FTA bilateral firmado antes de 2009 tinha como parceiro um país latino-americano, o México. Este acordo permaneceu como único exemplar deste tipo FTA bilateral - em vigor durante um período de quase uma década e meia, demonstrando não representar uma estratégia com comércio internacional adotada pelo país. A figura 1 abaixo ilustra o cenário de FTAs na Colômbia até 2009, ano em que o país assume nova visão, ampliando seus parceiros no livre comércio, conforme novo cenário que consta na figura 2.

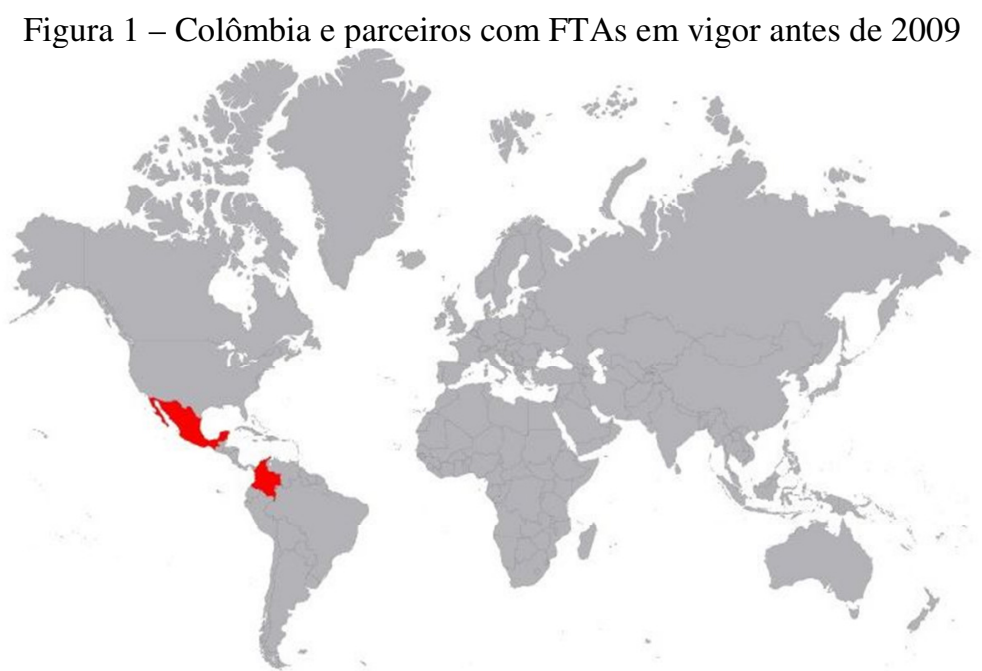

Fonte: Elaborado com base no quadro acima

A figura abaixo demonstra que as negociações bilaterais de FTAs após 2009 se expandem significativamente em quantidade, marcando uma tendência, e também geograficamente, rumando para além da América do Sul e América Latina, alcançando a América do Norte, bem como a Europa. Para deixar completo o panorama de parceiros comerciais da Colômbia, a figura congrega todos os FTAs em vigor no país. 


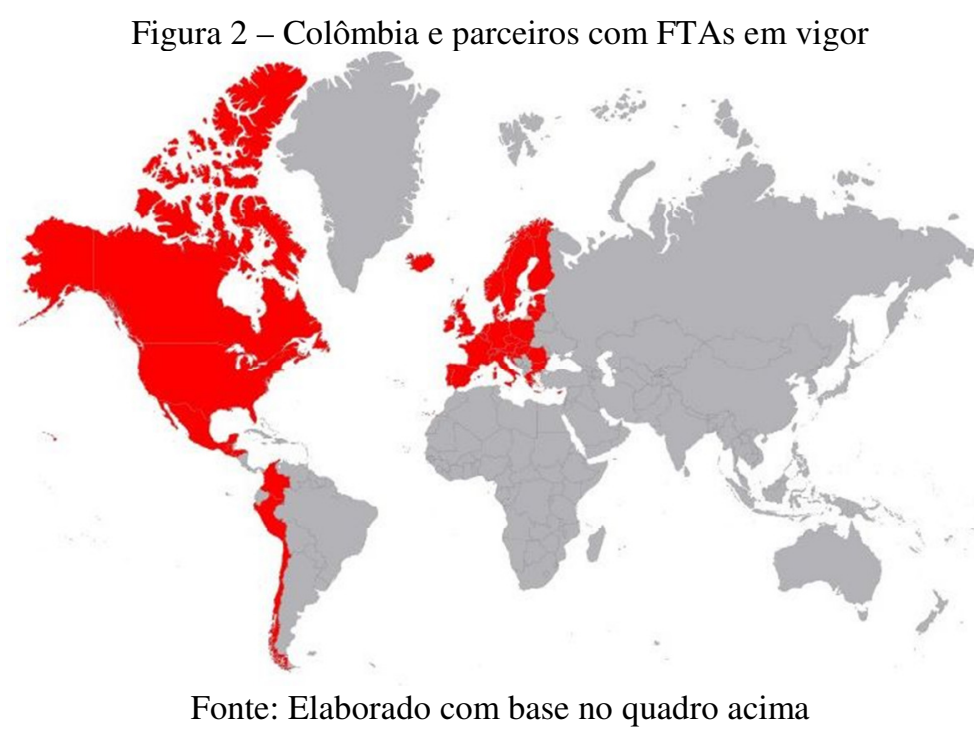

Por meio de uma análise comparativa das figuras 1 e 2 fica clara esta forma de atuação como uma tendência nova, com o ano de 2009 como marco, quando o mundo sentia os efeitos da crise financeira e imobiliária iniciada em 2008. Nesta conjectura, passou-se a buscar nova forma de atuação, com a qual a Colômbia deve-se manter fiel, uma vez que o país dispões de outros FTAs em processo de negociação.

Ao observar os acordos preferenciais de comércio firmados pelo Peru, identifica-se a mesma tendência evidenciada com relação à Colômbia, todavia mais acentuada, já que este país não dispunha de nenhum acordo de livre comércio de negociação bilateral até então, e a partir de 2009 foram firmados treze desses, sendo somente um com país da América do Sul, novamente o Chile, protagonista principal na negociação de FTAs bilaterais na região.

Entre os demais parceiros do Peru em PTAs estão os EUA, Canadá e México na América do Norte, Panamá e Costa Rica na América Central, e EU e EFTA no continente europeu, além dos países asiáticos China, Cingapura, Coréia e Japão. Esta expansão para outras regiões com a aproximação aos países fronteiriços ao Oceano Pacífico, conforme demonstrado também pelos recentes acordos de integração regional envolvendo os países desta região é outra tendência que começa a se fortalecer entre os países de visão liberalbilateralista. Anteriormente o Peru detinha somente acordos preferenciais de caráter multilateral datados dos anos oitenta, sendo eles ALADI, CAN e GSTP, além do PTN ${ }^{15}$.

\footnotetext{
${ }^{15}$ PTN, da sigla em inglês Protocol on Trade Negotiations: acordo comercial preferencial assinado em 09 de dezembro de 1971 com o objetivo de aumentar o comércio entre os países em desenvolvimento no âmbito do Acordo Geral sobre Tarifas e Comércio.
} 
Quadro 4 - PTAs Peru - Acordos em vigor

\begin{tabular}{|l|l|l|}
\hline \multicolumn{1}{|c|}{ Nome do Acordo (inglês) } & \multicolumn{1}{c|}{ Tipo } & \multicolumn{1}{c|}{ Entrada em vigor } \\
\hline Costa Rica - Peru & FTA \& EIA & $01 / 06 / 2013$ \\
\hline EU - Colombia and Peru & FTA \& EIA & $01 / 03 / 2013$ \\
\hline Panama - Peru & FTA \& EIA & $01 / 05 / 2012$ \\
\hline Japan - Peru & FTA \& EIA & $01 / 03 / 2012$ \\
\hline Peru - Mexico & FTA \& EIA & $01 / 02 / 2012$ \\
\hline Peru - Korea, Republic of & FTA \& EIA & $01 / 08 / 2011$ \\
\hline EFTA - Peru & FTA & $01 / 07 / 2011$ \\
\hline Peru - China & FTA \& EIA & $01 / 03 / 2010$ \\
\hline Peru - Singapore & FTA \& EIA & $01 / 08 / 2009$ \\
\hline Canada - Peru & FTA \& EIA & $01 / 08 / 2009$ \\
\hline Peru - Chile & FTA \& EIA & $01 / 03 / 2009$ \\
\hline US - Peru & FTA \& EIA & $01 / 02 / 2009$ \\
\hline $\begin{array}{l}\text { Global System of Trade Preferences among } \\
\text { Developing Countries (GSTP) }\end{array}$ & & \\
\hline Andean Community (CAN) & PSA & $19 / 04 / 1989$ \\
\hline Latin American Integration Association (LAIA) & PU & $25 / 05 / 1988$ \\
\hline Protocol on Trade Negotiations (PTN) & PSA & $18 / 03 / 1981$ \\
\hline Fo RTA-IS / OMC & $11 / 02 / 1973$ \\
\hline
\end{tabular}

Fonte: RTA-IS / OMC

Comparativamente ao mapa de FTAs em vigor na Colômbia, ressalta-se no mapa de FTAs em vigor no Peru que os acordos chegam ao continente asiático, exacerbando a tendência extra regional deste tipo de acordos, bem como a tendência de enfoque nos países asiáticos banhados pelo Oceano Pacífico. Outro ponto importante é a intensidade na qual o país assume esta política de comércio internacional, com uma rápida expansão na negociação de FTAs.

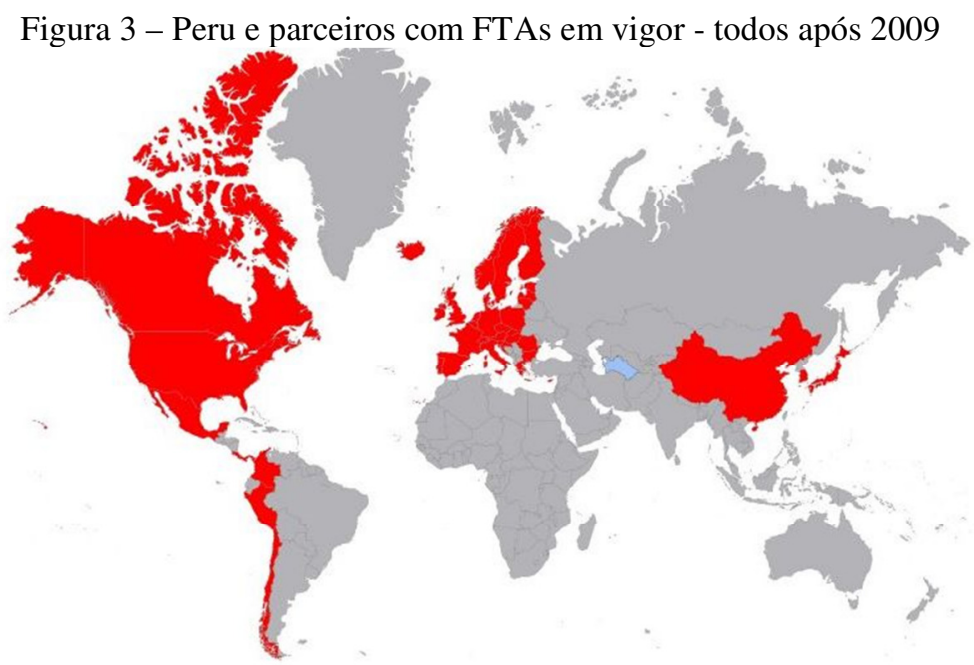

Fonte: Elaborado com base no quadro acima

Apresenta-se somente uma figura com mapa do Peru, pois não há o que se comprar em questão temporal, visto que antes do período em foco o país não tinha FTAs em vigor. 
Entre os três países que adotam a visão Liberal-bilateralista na América do Sul, o Chile não tem sua estratégia de negociação de FTAs bilaterais iniciada no mesmo período, mas já a partir de 1997. Tem-se, portanto, nesse país andino, a assinatura de FTAs por meio de negociações bilaterais como política de comércio internacional de longo prazo, havendo iniciado no final dos anos noventa e permanecendo de maneira contínua até hoje.

Quadro 5 - PTAs Chile - Acordos em vigor

\begin{tabular}{|l|l|l|}
\hline \multicolumn{1}{|c|}{ Nome do Acordo (inglês) } & \multicolumn{1}{c|}{ Tipo } & \multicolumn{1}{c|}{ Entrada em vigor } \\
\hline Hong Kong, China - Chile & FTA \& EIA & $09 / 10 / 2014$ \\
\hline Chile - Nicaragua (Chile - Central America) & FTA \& EIA & $19 / 10 / 2012$ \\
\hline Chile - Malaysia & FTA & $25 / 02 / 2012$ \\
\hline Turkey - Chile & FTA & $01 / 03 / 2011$ \\
\hline Chile - Guatemala (Chile - Central America) & FTA \& EIA & $23 / 03 / 2010$ \\
\hline Chile - Colombia & FTA \& EIA & $08 / 05 / 2009$ \\
\hline Australia - Chile & FTA \& EIA & $06 / 03 / 2009$ \\
\hline Peru - Chile & FTA \& EIA & $01 / 03 / 2009$ \\
\hline Chile - Honduras (Chile - Central America) & FTA \& EIA & $19 / 07 / 2008$ \\
\hline Panama - Chile & FTA \& EIA & $07 / 03 / 2008$ \\
\hline Chile - Japan & FTA \& EIA & $03 / 09 / 2007$ \\
\hline Chile - India & PSA & $17 / 08 / 2007$ \\
\hline & & $01 / 10 / 2006(G) /$ \\
Chile - China & FTA \& EIA & $01 / 08 / 2010(\mathrm{~S})$ \\
\hline Trans-Pacific Strategic Economic Partnership & FTA \& EIA & $28 / 05 / 2006$ \\
\hline EFTA - Chile & FTA \& EIA & $01 / 12 / 2004$ \\
\hline Korea, Republic of - Chile & FTA \& EIA & $01 / 04 / 2004$ \\
\hline US - Chile & FTA \& EIA & $01 / 01 / 2004$ \\
\hline EU - Chile & FTA \& EIA & $01 / 02 / 2003(\mathrm{G}) /$ \\
\hline Chile - El Salvador (Chile - Central America) & FTA \& EIA & $01 / 06 / 2002$ \\
\hline Chile - Costa Rica (Chile - Central America) & FTA \& EIA & $15 / 02 / 2002$ \\
\hline Chile - Mexico & FTA \& EIA & $01 / 08 / 1999$ \\
\hline Canada - Chile & FTA \& EIA & $05 / 07 / 1997$ \\
\hline Global System of Trade Preferences among & PSA & $19 / 04 / 1989$ \\
\hline Developing Countries (GSTP) & PSA & $18 / 03 / 1981$ \\
\hline Latin American Integration Association (LAIA) & PSA & $11 / 02 / 1973$ \\
\hline Protocol on Trade Negotiations (PTN) & & \\
\hline & & \\
\hline
\end{tabular}

Fonte: RTA-IS / OMC

Antes de assumir esta política de comércio internacional, o Chile tinha em sua lista de PTAs em vigor somente o PTN da década de setenta, bem como a participação na ALADI e o GSTP datadas dos anos oitenta. Lembra-se, ainda que o Chile foi um dos membros fundadores do Pacto Andino em 1969 onde permaneceu até 1976, quando procedeu com sua retirada deste bloco, marcando o abandono da estratégia de negociações multilaterais e 
assumindo sua estratégia independente de liberalização do comércio por meio de tratados bilaterais.

Entre 1998 e 2003, quatro tratados foram firmados nestes moldes, agregando ao portfólio de países com o qual o Chile tem livre comércio o México, Costa Rica, El Salvador e União Europeia. E, antes disso, em 1997 o primeiro tratado foi firmado com Canadá,

Entre 2004 e 2008, o Chile negociou um total de nove PTAs, incluindo os EUA, EFTA, Panamá e Honduras, além de Coréia, China e Japão, que juntamente com o TPP indicam já neste período a tendência de negociações com países asiáticos que não somente permanece, mas se acentua nos países liberais-bilateralistas. Entre estes tratados, somente sete foram tratados bilaterais para o estabelecimento de livre comércio, pois um foi o TPP com suas características específicas e o outro um Acordo de Alcance Parcial com a Índia. O Chile foi um dos primeiros países no qual o TPP entrou em vigor e, embora seja oficialmente um acordo multilateral pelo fato de envolver vários países, seus moldes de negociação são pautados em acordos bilaterais.

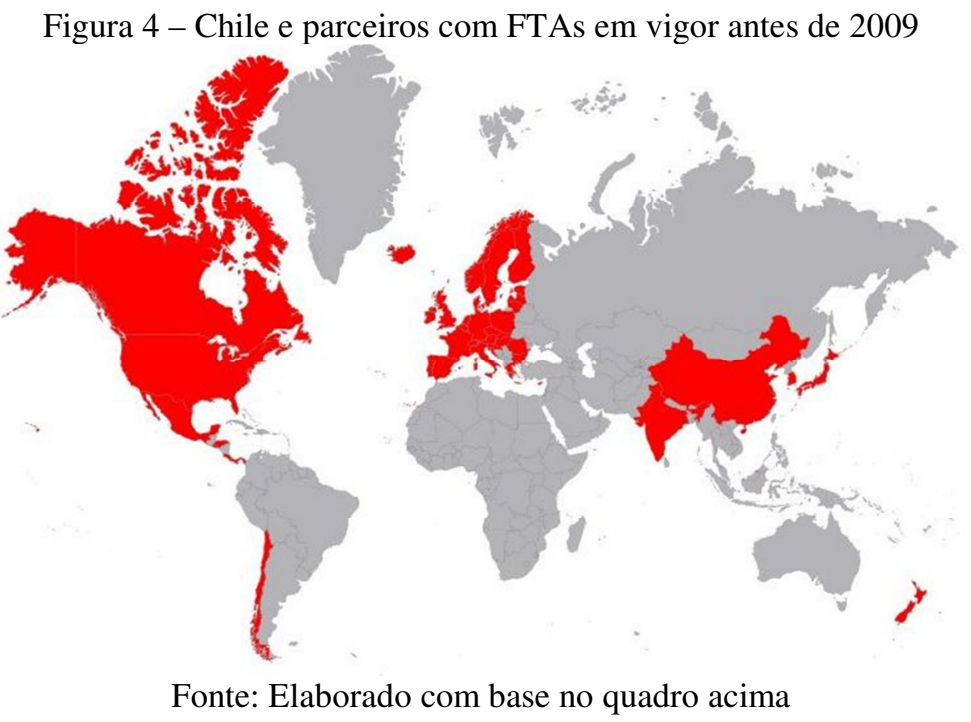

Desde 2009 e seguindo até 2014, período focal no qual se notou o início da referida tendência na Colômbia e no Peru, o Chile teve oito FTAs firmados, incluindo como parceiros esses dois países sul-americanos também pertencentes ao eixo Liberal-bilateralista e somando-se a eles Austrália, Guatemala, Turquia, Malásia, Nicarágua e Hong Kong. Chegase atualmente a vinte e um FTAs com os mais diversos países de diversas regiões sendo sua maioria bilateral - tendo um país ou um bloco como outra parte, além de um PSA com a Índia datado de quando o país já adotava a política de negociações bilaterais focada em FTAs, 
porém vê-se que a Índia tem como política firmar tratados mais restritivos e não tratados de livre comércio, conforme constatado quando da análise de suas relação com o MERCOSUL.

Figura 5 - Chile e parceiros com FTAs em vigor

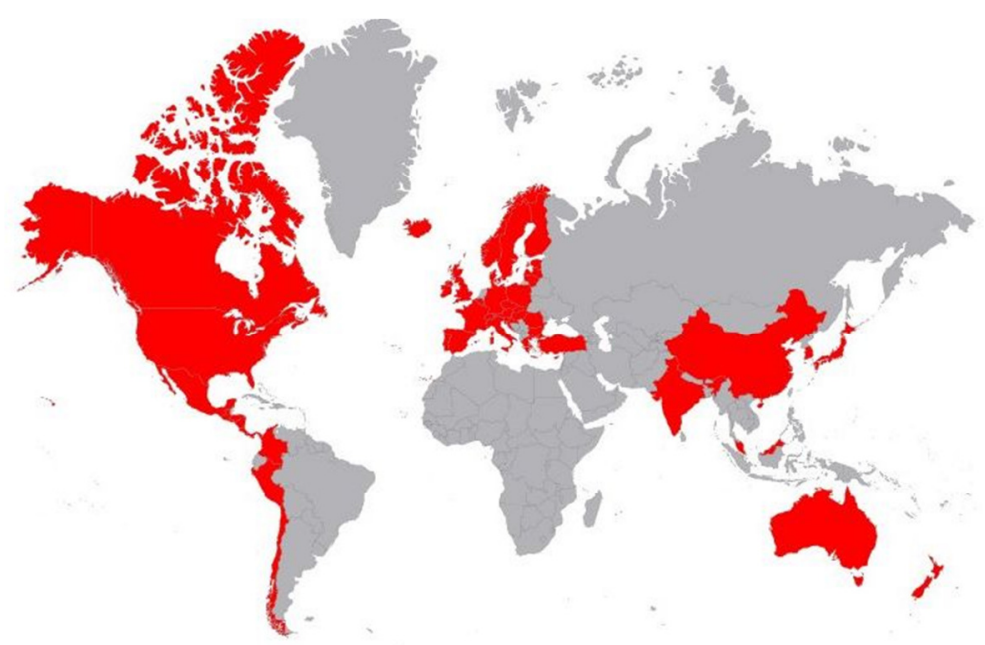

Fonte: Elaborado com base no quadro acima

Apesar de a comparação entre as figuras 4 e 5 não apresentar diferenças tão drásticas como nos mapas da Colômbia e do Peru - este sequer tem dois mapas para serem comparados, pois a adoção desta estratégia realmente foi iniciada em 2009 - ressalta-se que o Chile segue continuamente avançando na direção do livre comércio por meio da negociação de FTAs bilaterais. A questão temporal no Chile não é tão marcada como nos outros países, já que este país iniciou esta forma de atuação anteriormente. $\mathrm{O}$ fato de as figuras não serem muito discrepantes ocorre essencialmente em razão de alguns países com os quais o Chile incrementou sua lista de parceiros de livre comércio apresentarem contornos geográficos pequenos, como é o caso de Hong Kong. Não obstante, note-se que na figura 5, a qual inclui os acordos entre 2009-2014, há a expansão da ligação com a América Central, tendo quase todos os países continentais - não as ilhas - como parceiros comerciais, também a inclusão de Peru e Colômbia como parceiros, e a ampliação da parceria na Oceania colorindo a Austrália no mapa. Ainda diferencia-se a figura 4 e a figura 5 por mais um parceiro na Europa e um na Ásia, sendo respectivamente a Turquia e a Malásia, coadunando com a tendência de pulverização geográfica dos FTAs, sem que fiquem limitados a países vizinhos.

Sobre a atuação deste país, Diniz trata que há vários anos o Chile adota uma política interna e externa -, muito mais identificada com os interesses norte-americanos do que com seus vizinhos do continente sul-americano (DINIZ, 2006, p. 81), a exceção de Peru e Colômbia que passaram também a acompanhar a visão liberal-bilateralista como política de comércio internacional. 
Diante dos detalhes estudados, constata-se que os países liberais-bilateralistas adotaram nos últimos anos o uso dos FTAs vislumbrando expandir seus mercados, agindo de forma independente com negociações bilaterais, deixando em segundo plano as negociações multilaterais. Outro ponto marcante é o início desta tendência na região verificado no ano de 2009, ou seja, após a eclosão da crise financeira mundial iniciada 2008. Anteriormente, como somente o Chile adotava esta postura, não se poderia falar em tendência regional. Hoje, a tendência justifica-se no comprovado crescimento deste tipo de atuação na região. Observase, ainda, as tendências relacionadas ao tipo de acordo, com o uso de um tipo específico de tratado, qual seja o FTA negociado bilateralmente, bem como à expansão geográfica das negociações, as quais extrapolam os limites regionais.

\subsubsection{Países de visão Regional -multilateralista}

Os quatro países representante do eixo regional-multilateralista na América do Sul também apresentam entre eles o mesmo perfil de tratados, evidenciando tal posicionamento. Brasil, Argentina, Paraguai e Uruguai são todos membros fundadores do MERCOSUL, que é um PTA multilateral do tipo união aduaneira e integração econômica. Todos eles são também membros da ALADI desde sua instituição.

Além desses dois tratados comuns a estes países de atuação multilateral, Brasil Paraguai e Uruguai tem entre seus PTAs o GSTP, e do PTN participam apenas Brasil e Argentina. Entre todos esses tratados multilaterais, o MERCOSUL tem um único exemplar de tratado bilateral com notificação ao Sistema de Informação de Acordos Regionais de Comércio da OMC que é comum a todos os seus membros, porém, não se trata de um acordo de livre comércio (FTA), mas de um acordo de alcance parcial (PSA) com a Índia, que vigora desde 2009. Embora abranja mais de dois países, por englobar os países do MERCOSUL e a Índia, é um tratado bilateral, no qual se tem como uma das partes um país - Índia, e como outra parte um bloco de integração - MERCOSUL. Ressalta-se o ano de entrada em vigor 2009, mesmo ano que marca a tendência a negociações bilaterais por parte dos países de posicionamento liberal. $\mathrm{O}$ acordo MERCOSUL-Índia foi o primeiro tratado bilateral negociado pelo bloco originário do Cone Sul com um país de fora do continente, e trata-se especificamente de um Acordo de Preferências Tarifárias Fixas (APTF). Reforça-se, portanto, a tendência de ampliação geográfica das negociações preferenciais, porém, não se trata de um acordo profundo, pois o PTA MERCOSUL-Índia cobre apenas 450 linhas tarifárias ofertadas 
pela Índia e 452 itens pelo MERCOSUL. Há, contudo, proposta de ampliação deste acordo em discussão, objetivando-se estabelecer uma área de livre-comércio futuramente.

Quadro 6 - PTAs Brasil, Argentina, Paraguai e Uruguai - Acordos em vigor

\begin{tabular}{|c|c|c|}
\hline Nome do Acordo (inglês) & Tipo & Entrada em vigor \\
\hline \multicolumn{3}{|l|}{ Brasil } \\
\hline MERCOSUR - India & PSA & $01 / 06 / 2009$ \\
\hline Southern Common Market (MERCOSUR) & CU \& EIA & $\begin{array}{l}\text { 29/11/1991(G)/ } \\
07 / 12 / 2005(\mathrm{~S})\end{array}$ \\
\hline $\begin{array}{l}\text { Global System of Trade Preferences among } \\
\text { Developing Countries (GSTP) }\end{array}$ & PSA & 19/04/1989 \\
\hline Latin American Integration Association (LAIA) & PSA & $18 / 03 / 1981$ \\
\hline Protocol on Trade Negotiations (PTN) & PSA & $11 / 02 / 1973$ \\
\hline \multicolumn{3}{|l|}{ Argentina } \\
\hline MERCOSUR - India & PSA & 01/06/2009 \\
\hline Southern Common Market (MERCOSUR) & CU \& EIA & $\begin{array}{l}\text { 29/11/1991(G)/ } \\
07 / 12 / 2005(\mathrm{~S})\end{array}$ \\
\hline $\begin{array}{l}\text { Global System of Trade Preferences among } \\
\text { Developing Countries (GSTP) }\end{array}$ & PSA & 19/04/1989 \\
\hline Latin American Integration Association (LAIA) & PSA & $18 / 03 / 1981$ \\
\hline \multicolumn{3}{|l|}{ Paraguai } \\
\hline MERCOSUR - India & PSA & $01 / 06 / 2009$ \\
\hline Southern Common Market (MERCOSUR) & CU \& EIA & $\begin{array}{l}29 / 11 / 1991(\mathrm{G}) / \\
07 / 12 / 2005(\mathrm{~S})\end{array}$ \\
\hline Latin American Integration Association (LAIA) & PSA & $18 / 03 / 1981$ \\
\hline Protocol on Trade Negotiations (PTN) & PSA & $11 / 02 / 1973$ \\
\hline \multicolumn{3}{|l|}{ Uruguai } \\
\hline MERCOSUR - India & PSA & 01/06/2009 \\
\hline Mexico - Uruguay & FTA \& EIA & $15 / 07 / 2004$ \\
\hline Southern Common Market (MERCOSUR) & CU \& EIA & $\begin{array}{l}\text { 29/11/1991(G)/ } \\
07 / 12 / 2005(\mathrm{~S})\end{array}$ \\
\hline Latin American Integration Association (LAIA) & PSA & $18 / 03 / 1981$ \\
\hline Protocol on Trade Negotiations (PTN) & PSA & $11 / 02 / 1973$ \\
\hline
\end{tabular}

Fonte: RTA-IS / OMC

Houve, ainda, outras negociações de acordos bilaterais do MERCOSUL com países ou blocos de regiões mais longínquas, situação concreta na qual se verifica empiricamente a tendência de ampliação geográfica das relações preferenciais de comércio. Estes países são Israel, SACU, Egito e Palestina ${ }^{16}$, porém, estes acordos não estão identificados na base de dados de RTAs da OMC por falta de notificação, sendo que entre eles somente o acordo com Israel está em vigor.

\footnotetext{
${ }^{16}$ Informações do MDIC disponíveis em http://www.desenvolvimento.gov.br
} 
Quadro 7 - PTAs do MERCOSUL com países de outros continentes

\begin{tabular}{|l|l|l|l|}
\hline Nome do Acordo & Tipo de Acordo & Data de Assinatura & Entrada em vigor \\
\hline MERCOSUL-Palestina & FTA & dezembro-11 & - \\
\hline MERCOSUL-Egito & FTA & agosto-10 & - \\
\hline MERCOSUL-Sacu & FTA & dezembro-08 & - \\
\hline MERCOSUL-Israel & FTA & dezembro-07 & abril-10 \\
\hline MERCOSUL-Índia & APTF & março-05 & junho-09 \\
\hline
\end{tabular}

Fonte: MDIC

Nota: Somente acordos com países ou blocos de outros continentes. Excluídos os acordos firmados no âmbito da ALADI.

Apesar de as datas de assinaturas dos tratados acima serem anteriores, as datas nas quais começaram a entrar em vigor esses acordos são perfeitamente condizentes com o período no qual se verifica o fortalecimento da tendência Liberal-bilateralista, sendo que as análises dos acordos notificados à $\mathrm{OMC}$ foram também realizadas com base nas datas de entrada em vigor. Ademais, nota-se que, dentre eles, somente o acordo com a Índia não se enquadra na tipologia FTA, cuja tendência já foi verificada. Contudo, a ampliação do acordo MERCOSUL-Índia já está em negociação. Oliveira (2012) trata estes acordos preferenciais fora da região como um dos vetores da estratégia de política de comércio internacional do Brasil - e do MERCOSUL - destacando uma mudança de foco dos países desenvolvidos para em desenvolvimento.

Por sua vez a realização de acordos regionais de comércio que envolvem países de
fora da América do Sul conforma um terceiro vetor da estratégia de negociação
comercial do Brasil, tendo foco, no primeiro momento, nas negociações da Alca -
com os Estados Unidos, fundamentalmente - e entre o Mercosul e a UE, bem como,
em seguida, em acordos comerciais com países em desenvolvimento, como Índia,
México, Israel, Egito, Cuba e África do Sul, por meio da Sacu (OLIVEIRA, 2012,
p.9).

Ainda em se tratando de país em desenvolvimento, na análise dos PTAs dos representantes da vertente regional-multilateralista, o Uruguai apresenta um acordo bilateral de livre comércio e de integração econômica com México, o qual foi notificado somente em 2013, mas que está oficialmente em vigor desde 2004.

Os demais acordos que afetam o comércio dos países regionais-multilateralistas são aqueles instituídos no âmbito da ALADI, em especial na figura dos Acordos de Complementação Econômica $(\mathrm{ACE})^{17}$, também negociados bilateralmente, porém, vinculados

\footnotetext{
${ }^{17}$ Acordos de Complementação Econômica (ACEs) são os que possuem maior destaque no âmbito da ALADI, objetivam promover a liberalização do comércio entre os países signatários do acordo e estão previstos no Artigo 11 do Tratado de Montevidéu 1980:

Artigo 11 - Os ajustes de complementação econômica têm por finalidade, entre outras, promover o máximo aproveitamento dos fatores da produção, estimular a complementação econômica, assegurar condições eqüitativas de concorrência, facilitar o acesso dos produtos ao mercado internacional e impulsar o desenvolvimento equilibrado e harmônico dos países-membros. Estes ajustes estarão sujeitos às normas específicas que forem estabelecidas para esses efeitos.
} 
a organização de cunho multilateral, conforme abordado mais adiante em análise específica sobre a política de comércio internacional do Brasil.

Observa-se no caso do Brasil e demais países do MERCOSUL o seu enfoque em tratados multilaterais, como a ALADI e o próprio MERCOSUL, sendo este o seu tradicional posicionamento como representantes da visão regional-multilateralista. Contudo, é possível perceber, conforme evidenciado no Quadro 6, que apesar de não ser de forma independente, mas por meio do bloco econômico do qual são parte, estes países passam a negociar FTAs em formato bilateral com países de outras regiões. Constata-se assim uma inclinação deste grupo de países à nova tendência sul-americana evidenciada, confirmando a tipologia - FTAs, a forma de negociação - bilateral, e a abrangência geografia - alcançando outros continentes. Não obstante identifiquem-se traços da tendência regional, é importante destacar que somente dois desses tratados estão atualmente em vigor, sendo que um deles - com a Índia - não é um acordo de livre comércio, apresentando-se mais restritivo. Todavia, outra tendência que se confirma é a questão temporal, posto que tais tratados entram em vigor também a partir de 2009, mesmo ano que marca a tendência nos países liberais bilateralista.

\subsubsection{Países de visão Extremo-nacionalista}

Com referência aos países de visão Extremo-nacionalista, Venezuela, Bolívia e Equador, os representantes deste posicionamento aparecem na lista de PTAs da OMC com um reduzido número de tratados vigentes, sendo eles acordos de caráter multilateral. O primeiro deles é a ALADI, datada de 1980, o segundo é a CAN, de 1988 e, por fim, o GSTP, firmado em 1989. Pode-se absorver deste cenário que não são países ativos em negociações comerciais internacionais, já que os mesmos permanecem fechados, e a abertura comercial não é parte de sua estratégia de política de comércio internacional. Porém, ao ampliar a análise para além da base de dados RTA-IS da OMC e retornando às movimentações sulamericanas de integração, conforme desenhado na figura 1, destaca-se primeiramente o fato de os três países serem membros da ALBA, conforme previamente abordado, e também de a Venezuela ter se retirado da CAN já em $2006^{18}$, e ter se tornado membro pleno do MERCOSUL em 2012. Esta ação parece ser parte de uma estratégia de aproximação da Venezuela com intensões políticas, na condição de principal país de visão extremo-

\footnotetext{
${ }^{18}$ Dado não atualizado na RTA-IS da OMC.
} 
nacionalista, dos países do Cone Sul. Neste sentido, parece coerente que Venezuela afaste-se da CAN, bloco no qual se encontram Peru e Colômbia com suas atuações neoliberais e direcione-se ao MERCOSUL, onde estão Brasil, Argentina, Paraguai e Uruguai em uma posição mais central.

Quadro 8 - PTAs Venezuela, Bolívia e Equador - Acordos em vigor

\begin{tabular}{|l|l|l|}
\hline \multicolumn{2}{|c|}{ Nome do Acordo (inglês) } & \multicolumn{1}{c|}{ Entrada em vigor } \\
\hline Venezuela & \multicolumn{2}{|c|}{} \\
\hline $\begin{array}{l}\text { Global System of Trade Preferences among } \\
\text { Developing Countries (GSTP) }\end{array}$ & PSA & $19 / 04 / 1989$ \\
\hline Andean Community (CAN) & CU & $25 / 05 / 1988$ \\
\hline Latin American Integration Association (LAIA) & PSA & $18 / 03 / 1981$ \\
\hline Bolívia & \multicolumn{2}{|l|}{} \\
\hline $\begin{array}{l}\text { Global System of Trade Preferences among } \\
\text { Developing Countries (GSTP) }\end{array}$ & PSA & $19 / 04 / 1989$ \\
\hline Andean Community (CAN) & CU & $25 / 05 / 1988$ \\
\hline Latin American Integration Association (LAIA) & PSA & $18 / 03 / 1981$ \\
\hline Equador & \multicolumn{2}{|l}{} \\
\hline $\begin{array}{l}\text { Global System of Trade Preferences among } \\
\text { Developing Countries (GSTP) }\end{array}$ & PSA & $19 / 04 / 1989$ \\
\hline Andean Community (CAN) & CU & $25 / 05 / 1988$ \\
\hline Latin American Integration Association (LAIA) & PSA & $18 / 03 / 1981$ \\
\hline
\end{tabular}

Fonte: RTA-IS / OMC

A Bolívia, acompanhando desta forma o movimento venezuelano, projeta-se também na direção do MERCOSUL, onde se encontra na condição de membro em processo de adesão a este bloco, porém sem promover sua retirada da CAN. O Equador tem posição ainda mais complexa com relação à integração regional, conforme já mencionado, posto que participa simultaneamente da CAN, da $\operatorname{ALBA}^{19}$ e do $\mathrm{ARCO}^{20}$. Apesar da contradição exposta pela participação em ações de integração detentoras de ideologias distintas, ao participar do ARCO o Equador confirma a tendência de expansão geográfica da integração, conforme já evidenciado nas políticas de comércio internacional de outros países, pois embora se trate de uma associação latino-americana, ela aponta para a criação de novos espaços de intercâmbio comercial, alternativos aqueles já existentes na região, ao ter como foco o comércio com países asiáticos.

Com referência a estes três países representantes do posicionamento extremonacionalista, não se vislumbra sua aderência às tendências que se identificam neste estudo, em

\footnotetext{
${ }^{19}$ A ALBA não está registrada no RTA-IS, pois é uma organização de cooperação, sem ter o comércio como foco.

${ }^{20}$ O ARCO não está registrado no RTA-IS, pois é um foro de cooperação em nível ministerial.
} 
razão de sua atuação ter embasamento em questões ideológicas e não em questões mercantis. A alteração que poderia ocorrer aproximando um pouco alguns destes países às tendências citadas seria em razão de a Venezuela ter passado a membro do MERCOSUL, sendo que os FTAs bilaterais do MERCOSUL incluiriam também este país. Embora haja esta possibilidade, questiona-se se o resultado da Venezuela como membro do bloco tradicionalmente do Cone Sul será a inclusão deste país nos FTAs do MERCOSUL ou se significará maior complexidade em negociar acordos desta natureza por falta de concordância do país de perfil nacionalista. O mesmo poderia ocorrer com Bolívia quando se tornar membro, bem como com Equador, caso venha um dia a tornar-se membro, visto sua aproximação ao bloco.

\subsubsection{Conclusões Gerais das Análises}

A partir da análise exposta acima, depreende-se que restam comprovados os quesitos temporal, geográfico, bem como relativo à forma de negociações acerca das tendências regionais de política de comércio internacional. Embora haja dois outros pontos também já evidenciados por meio das observações contidas nas sessões acima, busca-se aqui trazer informações que corroborem com a divisão dos países em três perfis de política de comércio internacional, bem como com relação à tipologia dos acordos que passam a ser predominantes na região.

O primeiro ponto fica também evidenciado na participação em PTAs, especialmente em FTAs, com base nos dados anteriormente mencionados, confirmando a fragmentação da América do Sul nas três vertentes divergentes de política de comércio internacional, o que resta claro de se visualizar frente ao mapa da América do Sul elaborado pela OMC sobre este tema. Enquanto Chile tem coloração mais intensa significando maior participação nestes acordos; Peru aparece na sequencia uma vez que assumiu este perfil de forma muito intensa, mesmo que recentemente; o próximo país de tom mais forte é a Colômbia, completando os três países de perfil liberal-bilateralista.

Os três países que aparecem em tons mais claros confirmando seu posicionamento mais fechado no perfil extremo-nacionalista são Venezuela, Bolívia e Equador. Finalmente, em tons intermediários aparecem os seguidores da vertente regional-multilateralista, sendo eles Brasil, Uruguai, Paraguai e Argentina, ou seja, os países membros fundadores do MERCOSUL. 


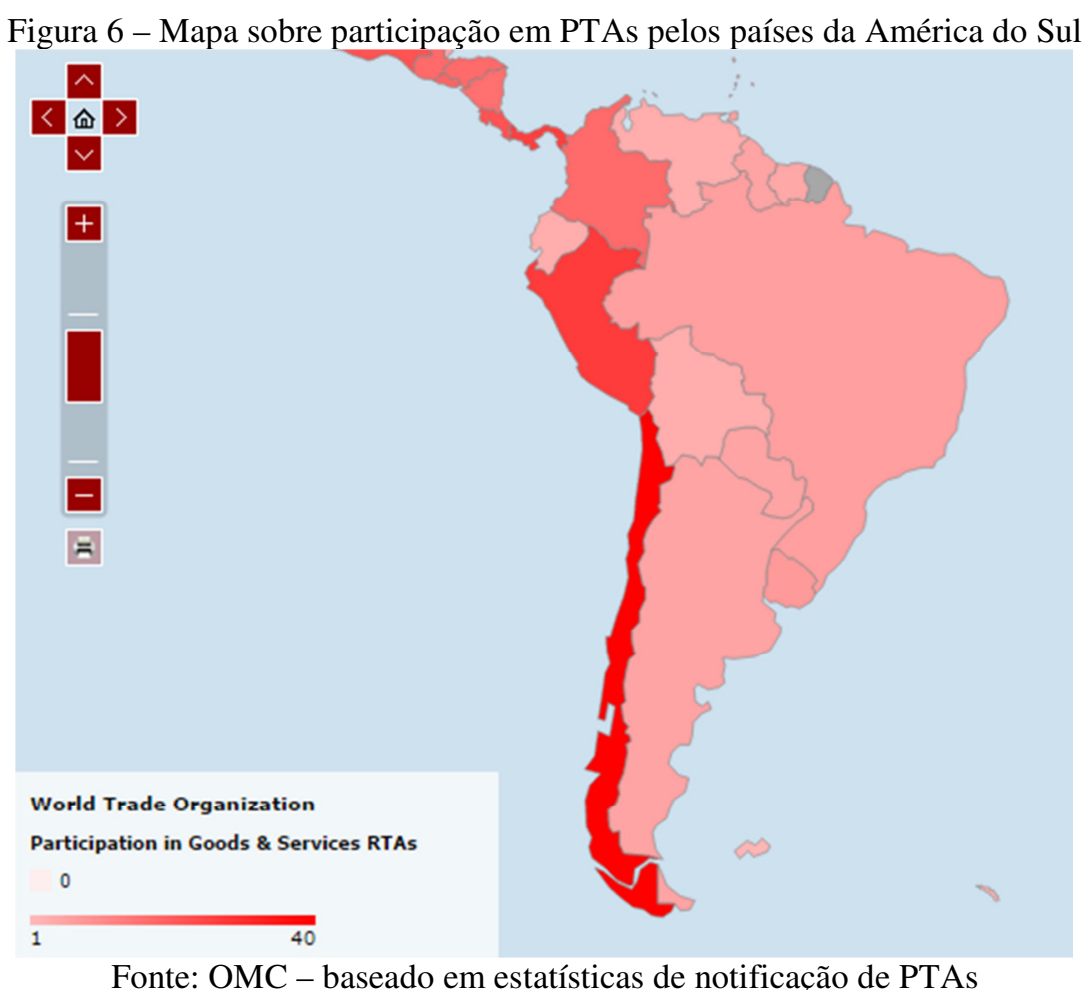

A partir das análises da lista de PTAs dos países em estudo, conclui-se que já estão devidamente evidenciadas duas tendências principais com relação às negociações internacionais preferenciais para a liberalização do comércio na América do Sul, as quais são características da vertente Liberal-bilateralista de política de comércio internacional, sendo elas concernentes à i) forma de negociação e ao ii) alcance geográfico.

Com referência à forma de negociação fica claro um retorno ao bilateralismo, com utilização de Acordos de Livre Comércio que também se afirma como tendência referente à tipologia, conforme se verifica à diante. Quanto ao alcance geográfico, embora ainda seja possível notar na América do Sul um interesse intra-zona, mesmo que difuso, não-coordenado e complexo em razão dos diversos organismos regionais coexistentes, destaca-se a ampliação do alcance geográfico das negociações realizadas por países da região, que cada vez mais extrapolam os limites regionais, chegando a outros continentes.

Malamud (2013) confirma as referidas tendências ao tratar que talvez a novidade mais importante esteja relacionada à negociação de acordos de livre comércio (FTA) entre as amplas regiões do mundo fora dos esquemas tradicionais da Organização Mundial do Comércio. (MALAMUD, 2013, p. 1).

Com relação à tipologia, a tendência ao uso de FTAs não é exclusividade da América do Sul, mas uma tendência dos tratados internacionais de comércio como um todo, conforme gráfico comparativo baseado nos FTAs registrados no sistema de informação de acordos preferenciais de comércio da OMC. Este gráfico mostra a ampliação do uso de FTAs no 
decorrer de períodos de cinco anos, sendo uma série representativa de todos os tratados em vigor registrados no RTA-IS e outra série exclusiva dos acordos que englobam países de América do Sul e encontram-se também devidamente notificados ao referido sistema.

A tendência mundial do uso de FTAs como forma de estabelecer preferências comerciais é bastante evidente com curva acentuada na direção crescente, cujo primeiro período no qual se identifica a tendência global de aumento nos FTAs é o início da década de noventa, e o ponto mais íngreme desta crescente data do período de 2004-2008.

Gráfico 1 - Tendência crescente do uso de FTAs

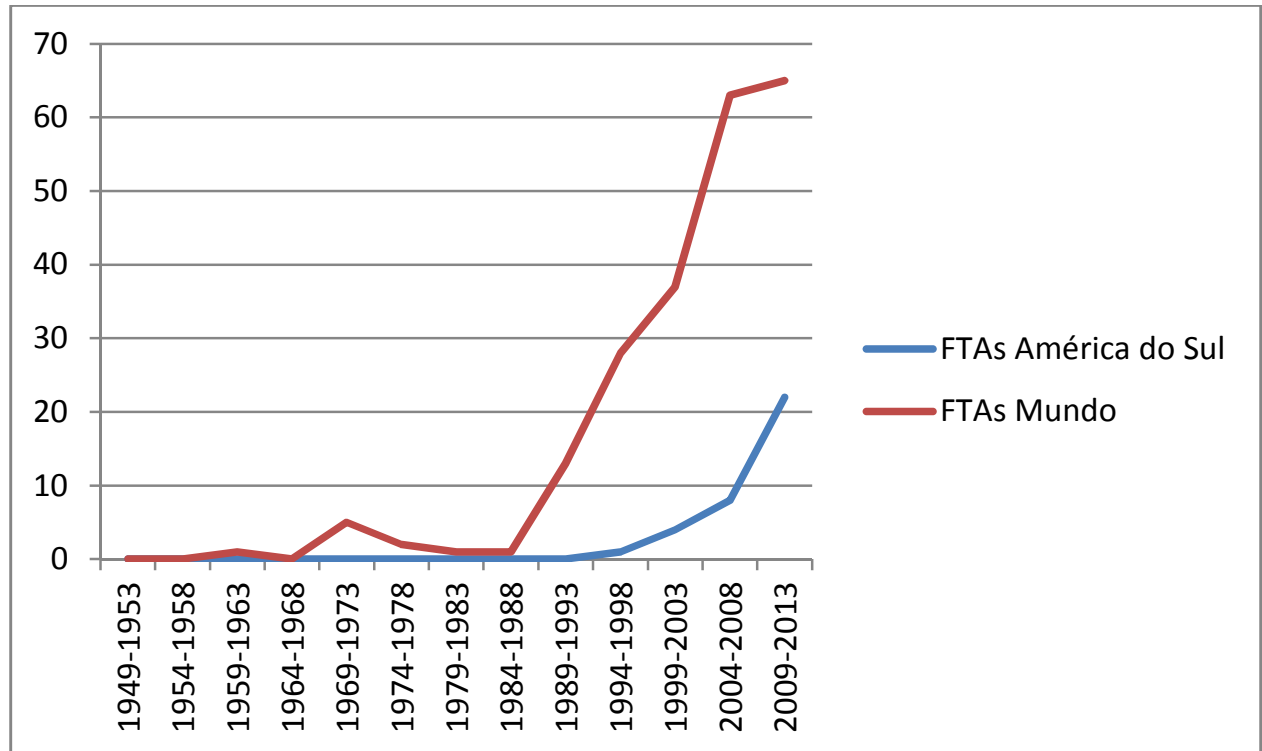

Fonte: RTA-IS / OMC

Nota: Gráfico elaborado pela autora com dados constantes dos Anexos.

No continente sul-americano tal tendência chega um pouco mais tarde, recorrendo-se a este tipo de acordo de forma mais acentuada a partir do início dos anos dois mil e com curva mais acentuada a partir de 2009, conforme já estudado, em razão da adoção deste tipo de negociação por parte de Colômbia e Peru.

Entretanto, seria possível que tal incremento no número deste tipo de acordo fosse um simples reflexo do desenvolvimento da integração que afeta o mundo de modo globalizado e que todos os tipos de acordos integracionistas houvessem aumentado no decorrer do tempo. Conforme Celli Junior (2012) os Acordos Preferenciais Comerciais vão continuar a existir e a se expandir e, ao citar o Relatório ${ }^{21}$ de Comércio da OMC de 2011, estabelece que tal fato está reconhecido pela organização, não havendo razão para se presumir que o número de Acordos Preferenciais Comerciais irá cessar de crescer ou que eles não serão parte do cenário das relações comerciais internacionais (CELLI JUNIOR, 2012, p. 95).

\footnotetext{
${ }^{21}$ WTO Trade Report - 2011 - The WTO Preferential Trade Agreements : from co-existence to coherence. Disponível em: www.wto.org
} 
Para que se comprove que o acréscimo de FTAs não se trata apenas de uma expansão natural e sim de uma tendência de tipologia de acordo que se torna cada vez mais procurada pelos Estados no estabelecimento de suas relações de comércio internacional, é possível fazer uma comparação com os acordos de união aduaneira (UA), que ocorrem em número absolutos bastante reduzidos em razão de ser um estágio de integração mais avançado, consequentemente mais complexo de se alcançar e menos procurado, porém, o uso de acordos de tipo UA tem recente redução, especialmente acentuada no período de 2009-2013, período que mostrou incremento do uso de FTAs.

Gráfico 2 - Tendência de redução do uso de UAs

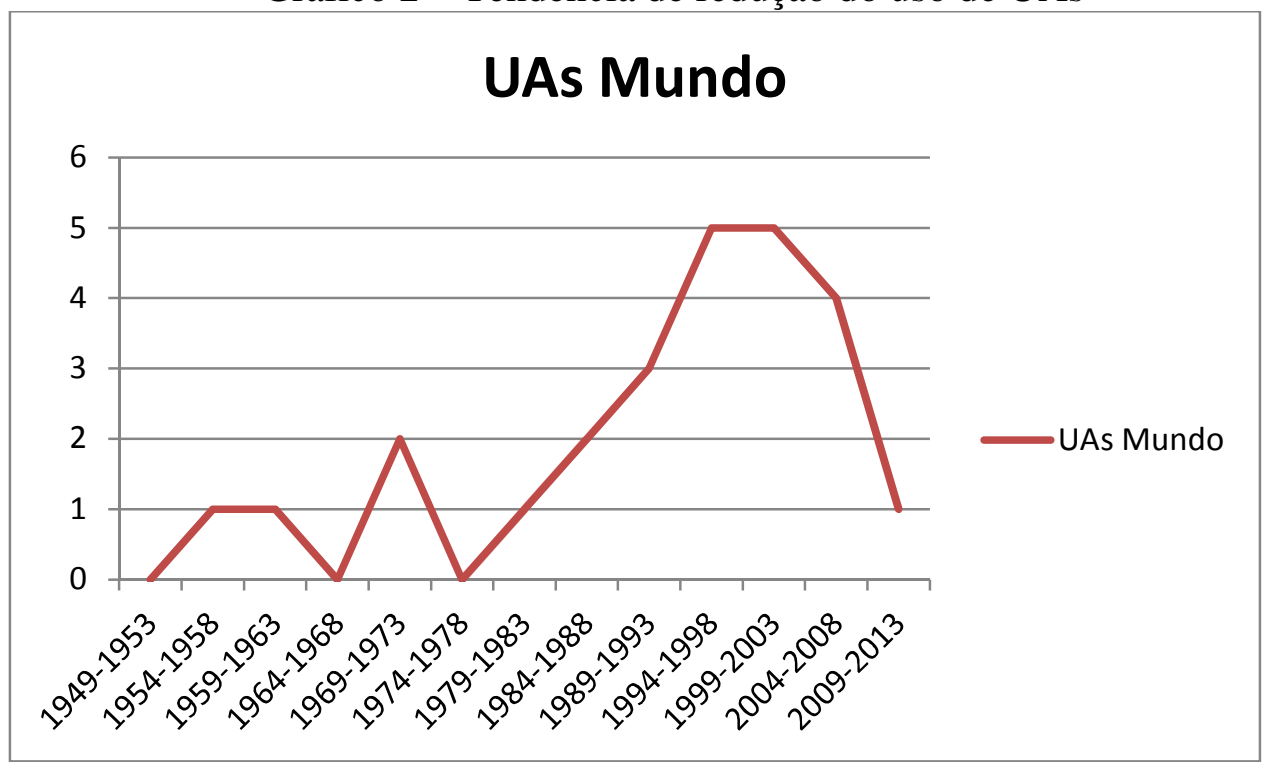

Fonte: RTA-IS / OMC

Nota: Gráfico elaborado pela autora com dados constantes do Anexo.

Deste modo, conclui-se com relação às tendências de acordos preferenciais de comércio que há uma crescente utilização de FTAs bilaterais na América do Sul, os quais extrapolam a questão regional, alcançando diversas área do mundo. Estas ações típicas dos países de visão Liberal-bilateralista marcam este posicionamento como tendência predominante na região. Embora haja movimentos relativamente tímidos, apesar de crescentes por parte do Brasil nesta direção, verifica-se que o país se mantem fortemente ligado a princípios como o multilateralismo e o regionalismo, criando-se, assim, um desafio à tradicional atuação brasileira em política de comércio internacional. 


\section{O Brasil e o desafio das tendências evidenciadas}

Diante das tendências evidenciadas neste estudo com a predominância da tendência à visão liberal-bilateralista na América do Sul, questiona-se quais os principais desafios para um país como o Brasil, que não está exatamente em consonância com referida tendência em matéria de politica de comércio internacional, embora mostre traços que se inclinam a esta vertente ao negociar alguns tratados bilaterais de livre comércio por intermédio do MERCOSUL.

Deste modo, pode-se apontar na atualidade como riscos ou desafios à atuação brasileira em política de comércio internacional os seguintes pontos principais:

i) A fidelidade à região da América do Sul

ii) A tímida integração comercial com os BRICS

iii) O multilateralismo como prioridade

iv) O novo olhar da região ao Pacífico e os desafios para o MERCOSUL

v) A exclusão do Brasil de projetos integracionistas globais

\subsection{A fidelidade à região da América do Sul}

O Brasil tem tradicionalmente mantido seu foco na região da América Latina, mais especificamente na América do Sul, conceito por ele criado e defendido, além de priorizar sua atuação no comércio internacional por meio das organizações multilaterais.

As relações internacionais do Brasil em sentido amplo estão norteadas pelos princípios constitucionais previstos no artigo $4^{\circ}$ da Constituição Federal de 1988:

Art. $4^{\circ}$ A República Federativa do Brasil rege-se nas suas relações internacionais pelos seguintes princípios:

I - independência nacional;

II - prevalência dos direitos humanos;

III - autodeterminação dos povos;

IV - não-intervenção;

V - igualdade entre os Estados;

VI - defesa da paz;

VII - solução pacífica dos conflitos;

VIII - repúdio ao terrorismo e ao racismo;

IX - cooperação entre os povos para o progresso da humanidade;

$\mathrm{X}$ - concessão de asilo político.

Parágrafo único. A República Federativa do Brasil buscará a integração econômica, política, social e cultural dos povos da América Latina, visando à formação de uma comunidade latino-americana de nações. 
No referido artigo, destaca-se para o contexto do presente trabalho relacionado à política de comércio internacional, o parágrafo único, que expressa a intenção de integração com a América Latina, tanto nas áreas sociais e culturais, quando em questões econômicas e políticas.

Neste sentido, as relações do Brasil dentro do escopo da ALADI são bastante coerentes com a busca pela integração latino-americana, pois desenvolve continuamente relações com os países dessa região. Mais exatamente no que concerne a América do Sul, é possível afirmar que o Brasil tem acordos comerciais com todos os países intra-região, seja por meio de tratados estabelecidos pelo MERCOSUL ou de forma independente, conforme demonstra o quadro de acordos firmados pelo Brasil na ALADI, confirmando sua propensão ao multilateralismo.

Quadro 9 - Acordos de Brasil ou MERCOSUL na ALADI
\begin{tabular}{|l|}
\hline Lista de Acordos firmados pelo Brasil no âmbito da ALADI \\
\hline Preferência Tarifária Regional entre países da ALADI (PTR-04) \\
\hline Acordo de Sementes entre países da ALADI (AG-02) \\
\hline Acordo de Bens Culturais entre países da ALADI (AR-07) \\
\hline Brasil - Uruguai (ACE-02) \\
\hline Brasil - Argentina (ACE-14) \\
\hline Mercosul (ACE-18) \\
\hline Mercosul - Chile (ACE-35) \\
\hline Mercosul - Bolívia (ACE-36) \\
\hline Brasil - México (ACE-53) \\
\hline Mercosul - México (ACE-54) \\
\hline Automotivo Mercosul - México (ACE-55) \\
\hline Mercosul - Peru (ACE-58) \\
\hline Mercosul - Colômbia, Equador e Venezuela (ACE-59) \\
\hline Brasil - Guiana (ACE-38) \\
\hline Brasil - Suriname (ACE-41) \\
\hline Brasil - Venezuela (ACE-69) \\
\hline Mercosul - Cuba (ACE-62) \\
\hline Fonte: MDIC
\end{tabular}

Segundo Simões, os vetores que orientam as relações do Brasil com a América do Sul são:

\footnotetext{
- primeiro vetor: a criação de novas condições para promover um crescimento sinérgico e solidário e,

- segundo vetor: a projeção política da América do Sul no contexto do reordenamento geopolítico mundial;

- terceiro vetor: estabelecimento de um quadro normativo e institucional de cooperação que permita potencializar o alcance de objetivos comuns;

- quarto vetor: o respeito à pluralidade (SIMÕES, 2012, p. 16)
} 
Tais vetores orientadores da atuação brasileira com relação a este subcontinente mostram uma posição já consolidada do país, que vem se projetando como líder regional e mantendo a abordagem regional-multilateralista em sua política de comércio internacional.

O fato de ter sido o Brasil o formulador do próprio conceito de América do Sul, bem como a importância econômica e política regional do país, leva a crer que a integração da região dependerá muito de como o Brasil a insere em sua estratégia de política externa (COSTA, 2013. p. 237). Assim, considerando o histórico integracionista com foco neste subcontinente, fica clara a posição central que a América do Sul ocupa na política externa do Brasil, refletida também na criação da UNASUL, contudo, em uma marcada predominância do interesse político. Todo esse protagonismo conferido ao Brasil com relação ao subcontinente, no entanto, pode sofrer profundas alterações com as mudanças na ordem e interesses mundiais, em especial em decorrência do novo olhar dos países de visão liberalbilateralista para o Pacífico, conforme já descrito.

O discurso de posse de Lula em seu primeiro mandato expressa o foco e a importância dada a esta sub-região:

\footnotetext{
"A grande prioridade da política externa durante o meu governo será a construção de uma América do Sul politicamente estável, próspera e unida, com base em ideais democráticos e de justiça social". Acrescentou que seriam estimulados os "empreendimentos conjuntos" e fomentado "um vivo intercâmbio intelectual e artístico". Prometeu apoiar os arranjos institucionais que se fizessem necessários para "que possa florescer uma verdadeira identidade do Mercosul e da América do Sul” (LULA DA SILVA, 2003, apud SANTOS, 2014, p. 145)
}

Santos (2014) confirma que realmente, no governo Lula, a América do Sul passou a ser a grande prioridade da política externa brasileira, sendo tal posicionamento demonstrado por diversos elementos, como o próprio fato de que, no plano do retórico, a expressão "América do Sul" passou a figurar em praticamente todos os discursos, entrevistas e textos relativos a temas internacionais (SANTOS, 2014, p. 149). A prioridade à América o Sul manteve-se como norte em ambos os mantados do Presidente Lula e também é identificada por Prazeres, que afirma que na administração Lula, uma série de iniciativas foi tomada para conferir, na prática, o destaque que se atribuiu à América do Sul no discurso.

\footnotetext{
A América do Sul passou a receber atenção renovada do governo brasileiro com a posse da nova administração em 2003. Além de reafirmar o compromisso do Brasil com o Mercosul, o governo Lula anunciou destaque a ser conferido às relações do país com a América do Sul (PRAZERES, 2006, p. 43).
}

Ao ser eleita sua sucessora, seria natural que a Presidente Dilma Rousseff mantivesse também este subcontinente como foco da política externa em geral, bem como da política de comércio internacional do país. Estes traços vetoriais foram identificados já em seu discurso de posse, que prometia continuidade ao governo precedente, porém, sem dar exclusividade à 
região, pois que a intenção de aprofundamento de relacionamento inclui praticamente todos os continentes. O que foi claramente mantido foi a busca da integração por meio do MERCOSUL e UNASUL.

\footnotetext{
Seguiremos aprofundando o relacionamento com nossos vizinhos sul-americanos; com nossos irmãos da América Latina e do Caribe; com nossos irmãos africanos e com os povos do Oriente Médio e dos países asiáticos. Preservaremos e aprofundaremos o relacionamento com os Estados Unidos e com a União Europeia. Vamos dar grande atenção aos países emergentes.

O Brasil reitera, com veemência e firmeza, a decisão de associar seu desenvolvimento econômico, social e político ao nosso continente.

Podemos transformar nossa região em componente essencial do mundo multipolar que se anuncia, dando consistência cada vez maior ao Mercosul e à Unasul. Vamos contribuir para a estabilidade financeira internacional, com uma intervenção qualificada nos fóruns multilaterais - Discurso de posse da Presidente Dilma Rousseff, 2011.
}

Finalmente, ainda de forma a reiterar a prioridade da região e a intenção de fortalecimento das organizações de integração ligadas à América do Sul e América Latina, o mais recente discurso de posse da Presidente Dilma Rousseff datado de primeiro de janeiro de 2015 traz o seguinte pronunciamento com este enfoque.

\begin{abstract}
Manteremos a prioridade à América do Sul, América Latina e Caribe, que se traduzirá no empenho em fortalecer o Mercosul, a Unasul e a Comunidade dos países da América Latina e do Caribe (Celac), sem discriminação de ordem ideológica. Agradeço, inclusive, a presença de meus queridos colegas e governantes da América Latina aqui presentes. Da mesma forma será dada ênfase a nossas relações com a África, com os países asiáticos e com o mundo árabe - Discurso de posse da Presidente Dilma Rousseff, 2015.
\end{abstract}

O discurso atual repercute novamente a visão regional-multilateralista, não obstante, não são esquecidas outras regiões no decorrer do pronunciamento, mostrando, ao menos retoricamente, a abertura para a intensificação das relações com outras regiões. Este é um dos principais desafios com o qual o Brasil se depara neste contexto, manter suas tradicional relação de proximidade à identidade sul-americana, região onde figura como líder, porém, sem que isso signifique estagnar sua relação com outras regiões.

\title{
3.2 A tímida integração comercial com os BRICS
}

O discurso brasileiro de política externa tem sido consistente nos últimos anos, com enfoque regional, negociações multilaterais, porém com uma estratégia autonomista. É esta estratégia que mantém o país comercialmente vinculado à região, porém, politicamente aberto a outras participações na esfera internacional. Por meio desta estratégia, o Brasil passou a intensificar suas relações Sul-Sul, com países de desenvolvimento econômico e social similar 
e com semelhantes necessidades e perspectivas de inserção no sistema internacional (COSTA, 2013. p. 244).

A intensificação das relações Sul-Sul com países de características similares, que é o caso dos BRICS, envolve novamente questões mais políticas que comerciais, buscando reforçar a posição destes países na arena internacional como potências emergentes. Os BRICS não são um bloco econômico, mas o nível da cooperação política entre seus membros sugere a importância de um discurso como grupo de potências emergentes, a fim de reforçar sua posição na arena internacional. Embora não haja coordenação referente às políticas de comércio internacional adotadas por estes países, que atuam de forma independente entre si, há certo grau de união em questão de negociações em âmbito multilateral, derivando daí maior protagonismo e força política em negociações na OMC.

Identifica-se também o crescimento de ligações econômico-comerciais entre os países citados, evidenciadas no Acordo de Preferências Tarifárias Fixas (APTF) MERCOSULÍndia $^{22}$, o primeiro do bloco sul-americano com país de outro continente, bem como MERCOSUL-SACU, que representa aproximação comercial com a África do Sul, extrapolando questões meramente políticas, porém ainda não em vigor. Restam demonstrados por meio da celebração desses tratados traços da tendência de ampliação geográfica extraregional das relações comerciais.

A intensão de aprofundamento das relações comerciais com os países emergentes foi também mencionada no discurso de posse do segundo mandato da Presidente Dilma.

\footnotetext{
Com os Brics, nossos parceiros estratégicos globais - China, Índia, Rússia e África do Sul-, avançaremos no comércio, na parceria científica e tecnológica, nas ações diplomáticas e na implementação do Banco de Desenvolvimento dos Brics e na implementação também do acordo contingente de reservas - Discurso de posse da Presidente Dilma Rousseff, 2015.
}

A relação do Brasil com os BRISC também constitui ponto crucial diante do quadro apresentado para a América do Sul. Não obstante a retórica de avanços nesta relação conforme discurso acima e alguns esforços conforme mencionado, especificamente no campo comercial a integração com os BRICS ainda é tímida, lenta e está longe de atingir seu

\footnotetext{
${ }^{22}$ O APTF está vigente desde 01/06/2009, conforme os Decretos $\underline{6.864}$ e $\underline{6.865}$ que se referem, respectivamente, ao texto do Acordo e ao modelo de certificado de origem a ser adotado pelas partes. Observa-se que a Portaria SECEX n ${ }^{\circ} 13,02 / 06 / 2009$, dispõe sobre a certificação de origem no âmbito do Acordo.

O anexo da Portaria SECEX $n^{\circ} 13$, de 02/06/2009, que contém o modelo do Certificado de Origem do APTF na versão de língua inglesa, foi substituido pelo anexo da Portaria SECEX n. ${ }^{\circ} 22$, de 24/07/2009;

O Acordo é formado por: Anexos I e II (listas de produtos), Anexo III (Regras de Origem), IV (Salvaguardas) e V (Solução de Controvérsias). (Fonte: MDIC)
} 
potencial. No entanto, é possível que futuros acordos tragam impactos profundos para os fluxos de comércio dos emergentes.

\subsection{O multilateralismo e o MERCOSUL como prioridade}

Tanto o multilateralismo quando o regionalismo, este representado pelo MERCOSUL, são prioridades para a atuação internacional brasileira, seja especificamente na área comercial ou em outros âmbitos. A relação entre as maiores economias do mundo, que inclui os países ditos emergentes acima é abordada por Diniz como fortalecimento do multilateralismo.

Os integrantes do G-20, organizados a partir da reunião de Cancún, congregando países como a China, Índia, África do Sul, Argentina, México e o próprio Brasil, representam a formação de ampla aliança que dá mostras de ser capaz de influir sobre vastas áreas do globo, a partir dos próprios foros internacionais e também de acordos regionais $\boldsymbol{e}$ multilaterais. Nesse novo contexto, mesmo que o multilateralismo passe a desempenhar um papel nitidamente acessório na estratégia dos Estados Unidos, ele mantém-se em cena pela atuação dos integrantes do G-20 (DINIZ, 2006, p.80).

De acordo com Oliveira (2012), o multilateralismo em sentido amplo, abrangendo tanto aspectos políticos quanto econômicos, é identificado pela política externa brasileira como espaço prioritário de atuação nas relações internacionais. $\mathrm{O}$ autor destaca este vetor da política de comércio internacional e reforça a importância dada a esta forma de atuação na política adotada pelo país.

No que concerne à análise da política comercial externa, cabe lembrar que o Brasil é membro fundador do regime multilateral de comércio. Assinou o GATT de 1947 e, desde então - embora tenha mantido participação ativa, mas secundária, fundamentalmente até a Rodada Uruguai -, tem crescido em importância no que concerne à capacidade de influenciar as negociações comerciais em curso no regime multilateral e de usar eficientemente seus mecanismos de solução de disputas comerciais. O trilho multilateral das estratégias comerciais do Brasil é, pois, longo e encontra fundamentos que o projetam e o reforçam enquanto caminho importante para a política comercial externa brasileira. (OLIVEIRA, 2012).

O multilateralismo é também reiteradamente defendido nos discursos oficiais brasileiros, como na ocasião da posse do Presidente Lula para seu segundo mandato em janeiro de 2007.

O fortalecimento de nosso sistema democrático dará nova qualidade à presença do Brasil na cena mundial. Nossa política externa, motivo de orgulho pelos excelentes resultados que trouxe para a nação, foi marcada por uma clara opção pelo multilateralismo, necessário para lograr um mundo de paz e de solidariedade. Essa opção nos permitiu manter excelentes relações políticas, econômicas e comerciais com as grandes potências mundiais e, ao mesmo tempo, priorizar os laços com o Sul do mundo. - Discurso de posse do Presidente Lula na cerimônia de Compromisso Constitucional perante o Congresso Nacional. Brasília, $1^{\circ}$ de janeiro de 2007 (BRASIL, 2007, p. 24) (grifo da autora). 
No mais recente discurso de posse, o multilateralismo é trazido novamente, aqui como um dos princípios norteadores da política internacional brasileira.

\begin{abstract}
Nossa inserção soberana na política internacional continuará sendo marcada pela defesa da democracia, pelo princípio de não-intervenção e respeito à soberania das nações, pela solução negociada dos conflitos, pela defesa dos Direitos Humanos, e pelo combate à pobreza e às desigualdades, pela preservação do meio ambiente e pelo multilateralismo. Insistiremos na luta pela reforma dos principais organismos multilaterais, cuja governança hoje não reflete a atual correlação de forças global. Discurso de posse da Presidente Dilma Rousseff 2015 (grifo da autora).
\end{abstract}

Diniz aponta que no século XXI a América do Sul encontra-se diante de alternativas contraditórias, em um quadro internacional extremamente complexo. Em um contexto de hegemonia americana, a autora identifica dois modelos, de um lado a proposta da ALCA e de outro a priorização do MERCOSUL. (DINIZ, 2006, p. 84-85). No entanto, no contexto detalhado da América do Sul conforme estudado e excluindo-se a possibilidade de adesão a um modelo de extremo-nacionalismo, a dicotomia para o Brasil está em manter o multilateralismo historicamente visto como ponto norteador de sua política de comércio internacional na busca do fortalecimento do MERCOSUL, ou assumir nova posição passando a atuar de forma independente estabelecendo relações bilaterais por meio de tratados de livre comércio com a intensão de expandir suas relações comerciais globalmente, conforme atuação dos países aqui classificados como Liberais-bilateralistas, que têm sua carteira

\title{
3.4 O novo olhar da região ao Pacífico e os desafios para o MERCOSUL
}

Da mesma forma que o Brasil estabelece atualmente relações mais próximas com alguns países de seu interesse na arena internacional, entre eles China, Índia, Rússia e África do Sul, os demais países sul-americanos dispõem de oportunidades fora da região. No entanto, em matéria de política comercial, o Brasil mantém sua visão regional-multilateralista, enquanto as oportunidades de alianças e associações que surgem para os países sulamericanos liberais têm foco na liberalização comercial voltada para fora do subcontinente sul-americano, de acordo com o que já foi apresentado tanto na sessão anterior quanto ao se tratar do regionalismo na América do Sul.

O desafios para o Brasil são muitos neste contexto. Destaca-se que alguns países da região passam a integrar organismos de integração dos quais o Brasil não participa e transferem seu foco de parcerias comerciais para fora do continente. A questão da estagnação 
do MERCOSUL e das suas recentes alterações também são preocupantes, a exemplo do caso da CAN, conforme descreve Portales (2013):

\begin{abstract}
Os intentos de fortalecimento da CAN chocaram-se com as mudanças políticas domésticas em vários de seus membros. A Venezuela com Hugo Chávez, a Bolívia sob a presidência de Evo Morales e finalmente o Equador com Rafael Correa criticaram a globalização e a abertura externa de suas economias, retomando orientações protecionistas. As divergências de orientação afetaram principalmente as negociações da CAN com países terceiros e erodiram o projeto comum. Nem a Venezuela, nem a Bolívia nem o Equador aceitaram as negociações com os Estados Unidos. O Peru e a Colômbia obtiveram TLC (FTAs) bilaterais, que entraram em vigor em 2010 e 2012, e a negociação da CAN com a União Europeia (UE) complicou-se e foi rompida em 2008, celebrando-se então um acordo da UE com a Colômbia e o Peru em 2010. A Venezuela havia se retirado da CAN em 2006. A continuidade da CAN só se explica por ser ela o marco para as correntes comerciais vigentes entre os atuais membros, que reconhecem preferências especiais para os países de menor desenvolvimento relativo (Bolívia e Equador) (PORTALES, 2013, p. 214).
\end{abstract}

Diante da nova configuração do MERCOSUL, com a Venezuela como membro e a Bolívia como membro em processo de adesão, ficam configuradas sérias divergências de orientação, as quais podem comprometer seriamente as evoluções futuras de tal instituição, em especial tendo em vista o fato de estarem esses países classificados, conforme este estudo, como extremo-nacionalistas, ou seja, em posição de contrariedade à evolução da abertura comercial. Confirmando este risco, o referido autor afirma que a recente incorporação da Venezuela após a suspensão do Paraguai, em 2012, e as negociações para o ingresso pleno da Bolívia e eventualmente do Equador assinalam uma mudança de prioridades: a ampliação do bloco sob sua estrita implementação e o aprofundamento das regulações comerciais. (PORTALES, 2013, p. 214). Ou seja, estas recentes alterações na participação no MERCOSUL, estabelecem uma ideia de ampliação do acesso ao comércio por meio de membros, rejeitando-se, de tal modo a possibilidade de crescimento através de parcerias comerciais pela assinatura de FTAs bilaterais. Por serem alterações recentes na configuração mercosulina, resta observar como caminharão as visões divergentes e como as mesmas refletirão na política de comércio internacional do bloco como um todo e dos países que dele participam individualmente.

Ao tratar especialmente das ações de integração envolvendo Chile, Colômbia e Peru, já estão claros os riscos incorridos pelo Brasil que há muito mantém seu foco no subcontinente sul-americano frente às ações voltadas ao Pacífico, conforme trata também Malamud (2012), ao relatar que a existência da Aliança do Pacífico supõe um grande desafio para o Brasil e seu projeto sul-americano sendo que a AP pode influir na natureza da liderança (ou não liderança) do Brasil na região. Impõe-se, por isso, o questionamento de o que será feito pelo governo brasileiro e pelo MRE frente a esta nova realidade. Segundo o autor, o 
Brasil terá que se movimentar frente à Aliança, na medida em que a mesma se consolide. Outro questionamento bastante complexo que emana desta conjuntura é se é possível uma liderança regional compartilhada. (MALAMUD, 2012, p. 4).

O fato de que o Uruguai participará da AP como observador aponta uma preocupação com o crescente isolamento do MERCOSUL, impulsionado pelas políticas comerciais da Argentina (que agora deve ser adicionado à Venezuela) e cria mais pressão ao governo do Brasil. (MALAMUD, 2013, p. 2).

A AP, bem como as demais ações de integração das quais participam somente os países que tem fronteira com o Oceano Pacífico, conforme visto, poderá representar uma dificuldade à projeção de líder regional do Brasil, pois que traz à América do Sul novos protagonistas, quais sejam os países de posicionamento liberal-bilateralista.

Caciamalli, Bobik e Celli Junior (2013) sumarizam a situação atual do Brasil e da região da seguinte forma.

\begin{abstract}
No plano das relações econômicas internacionais, o Brasil e seus parceiros do Mercosul concentraram seus esforços na conclusão da Rodada Doha da OMC. Outros países da região, ao contrário, como Chile, Colômbia e Peru, seguiram a tendência, sem precedentes na história das relações econômicas da região, de firmar acordos bilaterais de comércio com países centrais e com países de outras regiões, notadamente o Leste da Ásia. Enquanto os Estados Unidos, a União Europeia e a China, cada um com seus modelos específicos, ampliaram ou consolidaram o acesso a mercados de países estrategicamente importantes, o Mercosul, somente nos últimos dois anos, passou a perseguir a trilha dos acordos comerciais bilaterais, sem um modelo definido, no entanto. $\mathrm{Na}$ medida em que os resultados políticos, econômicos e sociais dos próximos anos do Brasil poderão ditar o padrão que será eventualmente seguido pela região no plano doméstico e em sua inserção mundial, é fundamental acelerar a celebração desses acordos comerciais e estabelecer um modelo equilibrado que permita a expansão comercial e a atração de investimentos, bem como a implantação de políticas de desenvolvimento. (CACIAMALLI; BOBIK e CELLI JUNIOR, 2013, p. 94)
\end{abstract}

Diante dos movimentos mais recentes do Brasil nesta esfera, acredita-se que haverá um equilíbrio entre estas duas posições, mantendo a tradicional atuação multilateral, porém, com determinada flexibilização quando ao regionalismo, dando abertura a negociação de FTAs bilaterais com novos parceiros comerciais de outras regiões, mas sendo estes negociados pelo MERCOSUL.

\title{
3.5 Novos projetos de integração regional e a exclusão do Brasil
}

Ao se ampliar a perfectiva das ações integracionistas para uma visão global, ou seja, além América do Sul, com enfoque nos movimentos que se estão configurando atualmente 
por meio de grandes conglomerados de integração regional em negociação, são identificados grandes riscos para o Brasil com relação a sua participação no cenário mundial.

Tais negociações são referentes ao i) TPP; ao ii) TTIP (Transatlantic Trade and Investment Partnership), que abarca uma série de negociações comerciais sigilosas entre a UE e os EUA, em formato bilateral para reduzir as barreiras regulamentares ao comércio para as grandes empresas; a iii) Euroasian Union, que aproxima a UE à Ásia por meio de uma união econômica de países desta região, bem como a iv) African Free Trade Zone, que congrega três blocos regionais africanos de comércio, formando uma zona única de livre comércio.

A nona edição da publicação Riscos Globais datada de 2014, elaborada pelo Fórum Econômico Mundo, estabelece que os objetivos econômicos domésticos aumentam a pressão sobre parcerias comerciais internacionais e diante da dificuldade de acordos multilaterais globais, os negócios que envolvem pequenos grupos de países estão em ascensão, com quadros extensos em negociação, conforme organismos representados na figura abaixo.

\section{Figura 7 - Novas Alianças Regionais de Comércio}

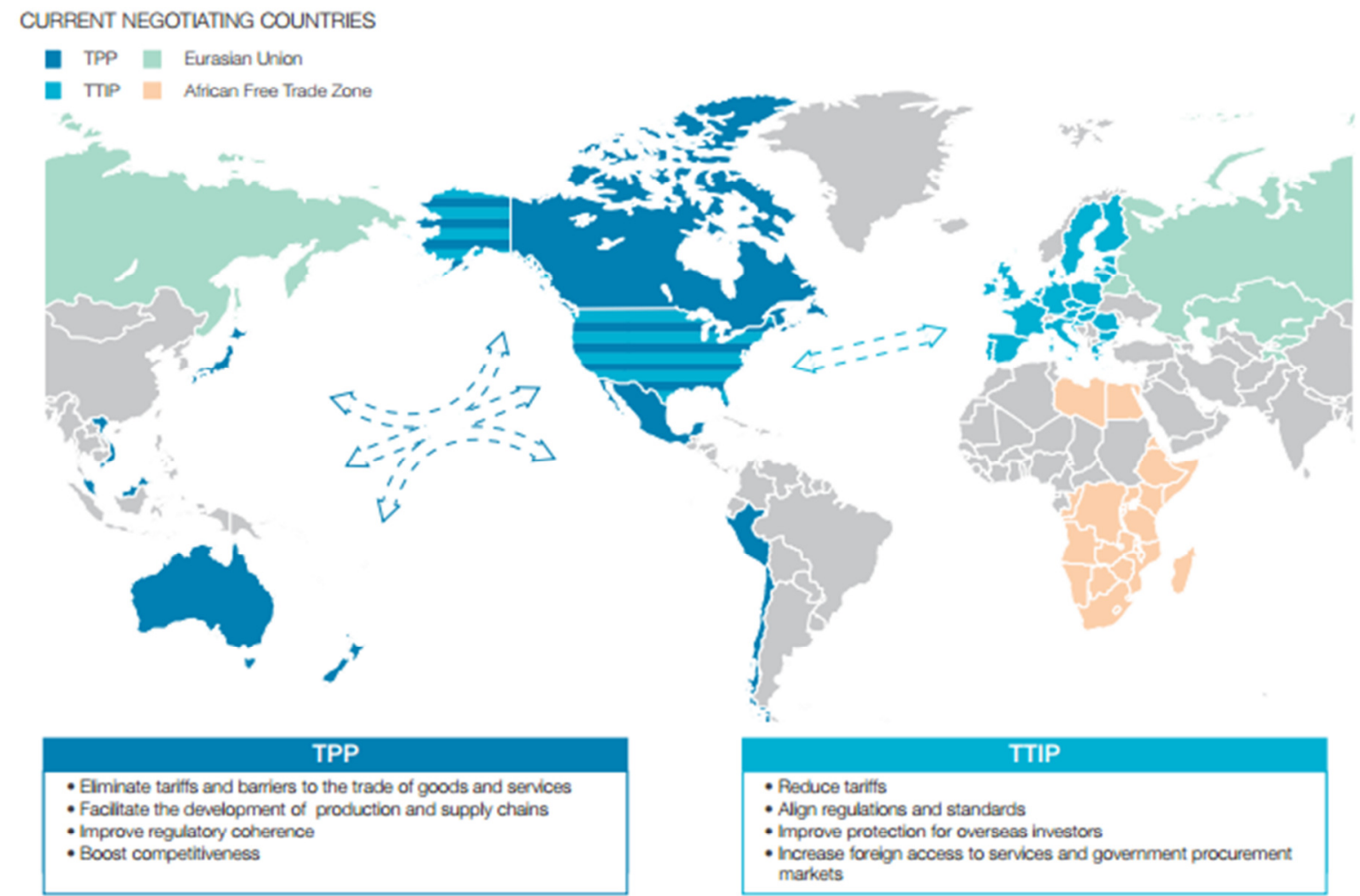

Fonte: Nona Edição de Riscos Globais 2014, publicada pelo Fórum Econômico Mundo.

Neste contexto conforme se pode depreender facilmente do mapa acima, é notável não somente o isolamento, mas a exclusão do Brasil dessas ações integracionistas com negociações em curso. Juntamente com os demais países sul-americanos não fronteiriços ao 
Oceano Pacífico, o Brasil não é chamado a fazer parte destes processos. Na realidade, neste panorama, a América do Sul, à exceção do Chile e Peru, resta preterida.

Nesta mesma situação encontram-se também outras potências emergentes como Índia e China. Portanto, os movimentos brasileiros em direção à integração, que são focados na região sul-americana e que recentemente se ampliam na direção dos países emergentes, resultam como possíveis caminhos para o país. Fora as referidas ações que já participam da pauta comercial internacional brasileira, a outra opção seria romper com os padrões atuais, e aproximar-se da visão liberal-bilateralista, passando a priorizar acordos bilaterais de livre comércio.

Para Sarquis (2011), a estratégia de promover o maior dinamismo comercial do Brasil deveria comportar linhas de ação global que deveriam também ser progressiva e complementarmente acompanhadas de reformulações e reorientações econômicas na inserção comercial brasileira.

Trata-se de buscar nas diferentes esferas de comércio bilateral, regional e interregional, assim como da perspectiva multilateral, um crescente padrão econômico Norte-Norte em nosso comércio. Indistintamente, esse padrão deveria ser almejado com economias tanto avançadas como emergentes. Em tal estratégia, não se procuraria negligenciar o comércio Norte-Sul, mas simplesmente torná-lo instrumento para relações mais dinâmicas e profícuas. É preciso adaptar as consideráveis pressões Norte-Sul, oriundas sobretudo da Ásia, em favor da continuidade da expansão de maiores correntes Norte-Norte (SARQUIS, 2011, p. 208).

Fica desta maneira constatada a relevância das ações de integração nas políticas de comércio internacional, com destaque ao fato de que o regionalismo está sempre em movimento, com o surgimento, extinção e transformação de organismos nas mais diversas regiões do planeta. Seguindo estes exemplos de conglomerados de integração que abarcam outros organismos formando um só, porém maior e mais fortalecido, a América do Sul, poderia conferir maior dinamicidade à região tirando a integração MERCOSUL-CAN do campo meramente retórico. Conclui-se, então, que as ações integracionistas, mesmo àquelas que não o envolvem, merecem a atenção do Brasil visto o risco de o país ficar de fora de importantes movimentos que alteram as configurações internacionais, além do que a sua exclusão das mais recentes ações em negociação favorecem os fluxos comerciais, sem a participação brasileira. 


\section{CONCLUSÃO}

Por meio da análise histórica das principais ações de integração ligadas a América do Sul entre segunda metade do século XX e as primeiras décadas do século XXI, buscou-se compreender o regionalismo sul-americano em suas diversas manifestações, passando pela ALALC e ALADI, Pacto Andino e CAN, MERCOSUL, ALBA, UNASUL, ARCO, AP e TPP, principais iniciativas neste sentido. Esta variedade e multiplicidade de organizações regionais presentes no subcontinente, adicionadas ao emaranhado de relações que elas estabelecem, resultam em sobreposições de posicionamentos divergente intra-região.

Assim, é importante estabelecer que as tentativas integracionistas, em geral, são bastante amplas e abrangentes, abarcando diversos assuntos e propósitos dentro de seu escopo. Enquanto na ALALC e ALADI o comércio pode ser considerado como núcleo do propósito de integração, no MERCOSUL tal relação também é encontrada, porém, a falta de resultados eficazes na consecução de um mercado comum, bem como as recentes alterações em sua configuração, enfraquecem a questão comercial como cerne, conferindo uma conotação mais política a esta organização de integração regional.

Este estudo se propôs, após traçar o histórico do regionalismo na área geográfica em foco, a estabelecer a relação das tentativas integracionistas com o comércio internacional e com as políticas de comércio internacional, concluindo-se que a centralidade do comércio no regionalismo é uma onda oscilante, ora mais enfatizada, ora menos.

$\mathrm{Na}$ sequência, identificou-se a fragmentação da região além dos processos de integração, utilizando-se para tal da classificação dos países de acordo com sua atuação no comércio internacional: i) Liberais-bilateralistas, ii) Regionais-multilateralistas, iii) Extremonacionalistas. Encontrou-se na literatura classificações bastante similares, que confirmaram a visão de que há três posicionamentos distintos em matéria de política de comércio internacional na região.

Enquanto os países de posicionamento Liberal-bilateralista, representados pelos países mais liberais fronteiriços ao Pacífico, quais sejam Chile, Colômbia e Peru, optam pelo uso cada vez mais intenso de FTAs negociados bilateralmente para seguir abrindo seus mercados, os países da vertente Regional-multilateralista mantem seu enfoque na integração regional e na atuação por meio de instituições multilaterais e neste grupo estão classificados Brasil juntamente com seus parceiros no MERCOSUL Argentina, Paraguai e Uruguai. Já os países do eixo extremo-nacionalista, Venezuela, Bolívia e Equador, participantes da ALBA, buscam 
manter seus mercados fechados por meio de ações nacionalistas, mesmo que as mesmas sejam incompatíveis com o sistema multilateral ou até mesmo ilegais.

Promoveu-se, então um estudo empírico baseado nos Acordos Preferenciais de Comércio (PTAs) que os referidos países tem em vigor utilizando-se como base de dados os acordos notificados a OMC e consequentemente constantes do Sistema de Informação de Acordos Regionais de Comércio (RTA-IS). Por meio desta análise, foi possível primeiramente confirmar a similaridade atuação entre os países de cada classificação e, na sequencia, conseguiu-se traçar as tendências que ganham força na região da América do Sul com relação aos acordos de comércio, identificando-se a predominância da utilização de acordos do tipo FTAs, com negociação bilateral, de abrangência geográfica variada e não limitada à região, além de haver uma tendência bastante marcada do uso desses acordos a partir de 2009.

Conclui-se, assim, haver um fortalecimento da visão liberal-bilateralista no continente sul-americano, sendo que as características desta vertente já começam a permear a política de comércio internacional do Brasil e do MERCOSUL, por meio da conclusão de FTAs em nome do bloco com países de fora da região. No entanto, este tipo de negociação no âmbito dos países de posicionamento regional-multilateralista ocorre em números reduzidos e, mais importante, tarda muito a entrar em vigor. Na esfera do MERCOSUL há somente um acordo exatamente nesses moldes vigorando até hoje, sendo que outros já foram negociados, porém não entraram em vigor.

Uma vez definida esta predominância da visão liberal-bilateralista, aponta-se os desafios que isso significa ao Brasil, sendo os principais a fidelidade brasileira à região sulamericana, sugerindo-se uma flexibilização deste vetor de política externa e maior abertura a outras regiões geográficas; a tímida integração comercial com os BRICS, sendo estes países emergentes parceiros de alinhamento político, porém com reduzidas ações concretas referentes ao comércio; multilateralismo como prioridade, posição que também merece ser reavaliada considerando-se a possibilidade de tratativa bilaterais; o novo olhar da região ao Pacífico e os desafios para o MERCOSUL, pois com as ações de integração voltadas ao Pacífico, o Brasil corre o risco de perder força em sua posição de liderança no subcontinente e; a exclusão do Brasil de projetos integracionistas globais também significa riscos para a participação do país na arena internacional. 


\section{POSSÍVEIS DESDOBRAMENTOS DE PESQUISA}

Embora uma pesquisa precise de um escopo bem definido, no processo de desenvolvimento da mesma surge uma série de novos caminhos possíveis de serem trilhados, que despertam a atenção e até mesmo a curiosidade.

Com o estudo apresentado e diante a dinamicidade da política externa, primeiramente surge a necessidade de acompanhamento da política de comércio internacional dos países sulamericanos de acordo com as três visões divergentes identificadas, objetivando avaliar se a tendência evidenciada permanece ganhando força no longo prazo e se há alterações nos perfis assumidos pelos países do subcontinente.

Outra caminho para a evolução do presente trabalho reside na ampliação da área geográfica em foco, abrangendo toda a América Latina. O histórico mais antigo dos países da região com relação a Políticas de Comércio Internacional já se confunde com o próprio histórico do regionalismo latino-americano, devendo-se, portanto, avançar em um estudo comparativo de períodos mais recentes nesta questão, buscando concluir se a tendência identificada na América do Sul se replica na América Latina, bem como se há ou não a mesma heterogeneidade nas visões de política externa voltadas ao comércio internacional aqui verificadas.

Dentre as diversas outras possibilidades de aprofundamento, levanta-se um ponto para a ampliação futura desta pesquisa sobre a América do Sul e sua Política de Comércio Internacional, qual seja a relação dos eixos assumidos pelos países com os partidos políticos de governo, em especial diante da recente ascensão da esquerda ao poder em diversos países da região. A estreita relação entre política externa e partidos de governo é fato conhecido em países como os Estados Unidos da América, onde a alternância de poder ocorre somente entre dois partidos, Republicano e Democrata, em posições ditas como antagônicas. O grande desafio, neste sentido, principalmente no caso do Brasil, no qual há um vasto número de partidos políticos e diferentes coligações a cada eleição, seria primeiramente definir o posicionamento de cada partido entre direita, esquerda e centro-esquerda, para somente então proceder com a análise.

O ponto mais crítico, contudo, e que resulta em maior interesse após esta pesquisa está no futuro do posicionamento do Brasil, tanto no campo prático quando na esfera ideológica, em matéria de política de comércio internacional, em especial, analisando a possibilidade de mudanças na histórica visão multilateralista adotada pelo país, por influência da tendência liberal-bilateralista identificada na América do Sul. Seria possível uma proposta de maior 
aproximação da visão Liberal-bilateralista por parte do Brasil? Quais os padrões ou vínculos teriam que ser rompidos neste caso? Seria juridicamente factível uma alteração mais radical nesta direção? Haveria compatibilidade com as ações integracionistas das quais o país participa, em especial com o MERCOSUL?

Finalmente, questiona-se para trabalhos futuros os impactos da tendência atual de abertura de mercado por meio de FTAs vista nos países de posicionamento Liberalbilateralista nos fluxos de comércio da região. As divergências nas Políticas de Comércio internacional na América do Sul geram desvios no comércio? Caso sejam verificados desvios, quais as possíveis soluções para compensá-los? Quais os danos efetivos que eles causam? Quais os países perdem e quais ganham neste cenário? É possível quantificar tais prejuízos?

Frente a tantos possíveis desdobramentos de pesquisa a serem explorados futuramente, resulta esta pesquisa como o início de muitos caminhos a serem percorridos no campo acadêmico, em especial com referência a esta região que merece cada vez mais ser estudada e compreendida no campo das relações internacionais. 


\section{REFERÊNCIAS}

ALMEIDA, Paulo Roberto de. O Brasil e a integração regional, da Alalc à Unasul: algum progresso? Boletim Mundorama, 2014. Disponível em: < http://mundorama.net/2014/06/11/o-brasil-ea-integracao-regional-da-alalc-a-unasul-algum-progresso-por-paulo-roberto-de-almeida/ $>$ Acesso em: $14 / 08 / 2014$

AMARAL, Antonio Carlos Rodrigues (coord.). Direito do Comércio Internacional. São Paulo: Aduaneiras, 2004. 395 p.

AMORIM, Celso. Discursos, palestras e artigos do Chanceler Celso Amorim: 2003-2010. V. I. Brasília: Ministério das Relações Exteriores, Departamento de Comunicação e Documentação: Coordenação-Geral de Documentação Diplomática, 2011. 316 p.

Discursos, palestras e artigos do Chanceler Celso Amorim:2003-2010. V. II. Brasília: Ministério das Relações Exteriores, Departamento de Comunicação e Documentação: CoordenaçãoGeral de Documentação Diplomática, 2011. 260 p.

BALASSA, BELA. The Theory of Economic Integration: An introduction. In: The Theory of Economic Integration. Greenwood Press: 1961. pp. 173-185. Disponível em: $<$ http://ieie.itam.mx/Alumnos2008/Theory\%20of\%20Economic\%20Integration\%20\%28Belassa\%29.p df > Acesso em: 20/10/2014.

BALDWIN, Richard. Multilateralising regionalism: spaghetti bowls as building blocs on the path to global free trade. NBER Working Paper Series, n.12545, 2006b. Disponível em: <file:///C:/Users/Bianca/Downloads/Document15102007200.5717584.pdf> Acesso em: 05/12/2014.

BARRETO, Irineu Pacheco Paes. A Transformação dos Conflitos: evolução recente e futura da sociedade peruana. In: Prêmio América do Sul- 2009 : Peru : evolução recente futura / Fundação Alexandre de Gusmão. Brasília : FUNAG, 2009. 136p.

BRASIL. Ministério das Relações Exteriores. Secretaria de Planejamento Diplomático. Repertório de política externa: posições do Brasil. - Brasília: Fundação Alexandre de Gusmão, 2007. 583 p.

BRASIL Discurso de posse de DILMA ROUSSEFF, 2011. Disponível em: $<$ http://www.brasil.gov.br/governo/2011/01/leia-integra-do-discurso-de-posse-de-dilma-rousseff-nocongresso> Acesso em: 02/01/2015.

CACCIAMALI, Maria Cristina; BOBIK, Márcio; CELLI JUNIOR, Umberto. Em busca de uma nova inserção da América Latina na economia global. Estud. av., São Paulo , v. 26, n. 75, 2012 - Disponível em: <http://www.scielo.br/scielo.php?script=sci_arttext\&pid=S0103$40142012000200007 \& \operatorname{lng}=\mathrm{en} \& \mathrm{nrm}=\mathrm{iso}>$. Acesso em: 15/11/2014.

CELLI JUNIOR, Umberto. A Organização Mundial do Comércio e o regionalismo do século XXI. In: Revista Densidades nº 9, 2012 pp. 91-107.

CERVO, Amado Luiz. Política de comércio exterior e desenvolvimento: a experiência brasileira. In: Revista Brasileira de Política Internacional. Vol.40. Brasília: 2007. Pp5-26. Disponível em: $<$ http://www.scielo.br/pdf/rbpi/v40n2/a01v40n2.pdf>. Acesso em: 10/10/2014.

COMUNIDADE ANDINA DE NAÇÕES. Disponível em: <http://www.comunidadandina.org/> Acesso em: 27/08/2013. 
DINIZ,Ângela Maria Carrato. Identidade, Desenvolvimento e Integração: Desafios para o Brasil e a América do Sul no Século XXI. In: O Brasil e a América do Sul: desafios no século XXI / Brasília: Fundação Alexandre de Gusmão: Instituto de Pesquisa de Relações Internacionais, 2006. p. $67-112$

GUIMARÃES, Samuel Pinheiro. A perspectiva brasileira de integração sul-americana. In: A América do Sul e a Integração Regional. Rio de Janeiro: Fundação Alexandre de Gusmão, 2011.

KATZ, Claudio. Gobiernos y Regimenes em América Latina. In: Los 90, fin de ciclo. El retorno de la contradicción. Editorial Final Abierto. Buenos Aires.

LAFER, Celso. A identidade do Brasil e a política externa brasileira: passado presente e futuro. São Paulo: Perspectiva, 2001. 124 p.

LESSA, Antônio Carlos. Há cinquenta anos a Operação Pan-Americana. Revista Brasileira de Política Internacional. Brasília: 2008, vol.51, n.2, pp. 5-7. Disponível em: $<$ http://www.scielo.br/pdf/rbpi/v51n2/v51n2a01.pdf> Acesso em: 28/08/2013.

LIMA, Jean Santos A Onda de Nacionalizações de Ativos Internacionais na América Do Sul no Século XXI: Necessidade Premente ou Política Ideologizada? Belo Horizonte: ABRI, 2013.

LYRA, Flavio Tavares de. O Brasil no processo de integração da América do Sul: evolução recente, problemas e complementaridades potenciais. Comissão Econômica Para a América Latina e o Caribe - CEPAL: 2007. 39 p. Disponível em: $<$ http://www.eclac.org/publicaciones/xml/5/32305/LCBRSR188FlavioTavaresdeLyra.pdf> Acesso em: 26/08/2013.

MALAMUD, Carlos. La Alianza del Pacífico: um revulsivo para la integración regional em América Latina. Real Instituto Elcano. ARI 46/2012 Disponível em: $<$ http://www.realinstitutoelcano.org/wps/wcm/connect/a151dd004bc4dc4bab27bbea9816c0d8/ARI462012_Malamud_Alianza_Pacifico_integracion_America_Latina.p6f?MOD=AJPERES\&CACHEID=a 151dd004bc4dc4bab27bbea9816c0d8> Acesso em: 05/05/2013

La Cumbre de la Alianza del Pacifico. Real Instituto Elcano. ARI 36/2013. Disponível em: <http://www.realinstitutoelcano.org/wps/wcm/connect/0055a2804fc9b26a832ecbccba746acc/Comenta rio-Malamud-Cumbre-Alianza-del-Pacifico-

2013.pdf?MOD=AJPERES \&CACHEID=0055a2804fc9b26a832ecbccba746acc $>$ Acesso em: $05 / 06 / 2013$

MENDOZA, Germán Umaña. La Trampa del Bilateralismo. Revista de Economía Institucional, vol. 12, n. 23, segundo semestre/2010, pp. 323-346 Disponível em: <http://www.economiainstitucional.com/pdf/No23/gumana23.pdf> Acesso em: 07/09/2013

MERCOSUL. Disponível em: <http://www.mercosur.int/>. Acesso em: 20/08/2013.

MINISTÉRIO DAS RELAÇÕES EXTERIORES DO BRASIL. Disponível em: < http://www.itamaraty.gov.br>. Acesso em: 20/08/2013.

NATAlinO, Enrique Carlos. O Peru entre Três Mundos: O Desafio da Transposição de Muros. In: Prêmio América do Sul- 2009 : Peru : evolução recente futura / Fundação Alexandre de Gusmão. Brasília : FUNAG, 2009. 136p.

NEVES, Rômulo Figueira. Cultura Política e Elementos de Análise da Política Venezuelana. Brasília: FUNAG, 2010. 152 p. 
OLIVEIRA, Henrique Altemani de. Política Externa Brasileira. São Paulo: Saraiva, 2005. 291 p.

OLIVEIRA, Ivan Tiago Machado. Política Comercial e Política Externa no Brasil: Uma Análise da Estratégia de Negociação Comercial Brasileira (1995-2010). Brasília: IPEA, 2012. 32p. Disponível em: <http://www.ipea.gov.br/portal/images/stories/PDFs/TDs/td_1765.pdf> Acesso em: $07 / 10 / 2014$

OLIVEIRA, Ivan Tiago Machado. Os Acordos Preferenciais e a Regulação do Comércio Global no Século XXI. 22p. In: Tendências Regulatórias nos Acordos Preferenciais de Comércio no Século XXI: os casos de Estados Unidos, Uniçao Europeia, China e Índia. Orgs: OLIVEIRA, Ivan Tiago Machado; BADIN, Michelle Ratton Sanchez. Brasília: IPEA, 2013. 332 p. Disponível em: < http://www.ipea.gov.br/agencia/images/stories/PDFs/livros/livros/livro_tendencias_regulatorias1.pdf> Acesso em: 05/07/2014

OMAN, Charles. Globalisation and Regionalisation: The Challenge for Developing Countries. Paris: OECD,1994. 138 p.

PINHEIRO, Letícia. MILANI, Carlos R. S. (Orgs.) Política externa brasileira: As práticas da política e a política das práticas. Rio de Janeiro: Editora FGV, 2012.

Política Externa Brasileira: Os Desafios de sua Caracterização como Política Pública. In: CONTEXTO INTERNACIONAL - vol. 35, no 1, janeiro/junho 2013. Disponível em: $<$ http://brasilnomundo.org.br/wp-content/uploads/2014/11/1artigo351.pdf >. Acesso em: 01/11/2014

PINTO, H.E.M. A Estratégia de Integração Econômica na América Latina: O Caso da Comunidade Andina. 2006. 308f. Tese (Doutorado) - Programa de Pós Graduação em Integração da América Latina - Prolam - Universidade de São Paulo

PORTALES, Carlos. Para onde vai o multilateralismo nas américas?: projetos superpostos num período de mudanças globais. Lua Nova, São Paulo , n. 90, Dec. 2013 . Disponível em: $<$ http://www.scielo.br/scielo.php?script=sci_arttext\&pid=S0102-

64452013000300008\&lng=en\&nrm=iso $>$. Acesso em: 17/12/2014 http://dx.doi.org/10.1590/S010264452013000300008 .

PRAZERES, Tatiana Lacerda. A integração sul-americana: uma ideia ainda fora do lugar? In: O Brasil e a América do Sul: desafios no século XXI / Brasília: Fundação Alexandre de Gusmão: Instituto de Pesquisa de Relações Internacionais, 2006. p. 13-66.

RATTMER, Henrique. Mercosul e Alca: o futuro incerto dos países sul-americanos. São Paulo: Editora da Universidade de São Paulo, 2002. 228 p.

RUSSELL, Roberto; TOKATLIAN, Juan G. Modelos de política exterior y opciones estratégicas: El caso de América Latina frente a Estados Unidos. In Revista CIDOB d'Afers Internacionals No. 85/86, LOS RETOS DE AMÉRICA LATINA EN UN MUNDO EN CAMBIO (MAYO 2009), pp. 211-249. Disponível em:http://www.jstor.org/stable/40586393

SAlOMÓN, Mônica. PINHEIRO, Letícia. Análise de Política Externa e Política Externa Brasileira: trajetória, desafios, e possibilidades de um campo de estudos. In: Revista Brasileira de Política Internacional. Vol. 56. Brasília: 2013. Pp 40-59. Disponível em: $<$ http://www.scielo.br/pdf/rbpi/v56n1/03.pdf> Acesso em: 01/12/2014.

SANTOS, Luís Cláudio Villafañe G. A América do Sul no discurso diplomático brasileiro. Brasília : FUNAG, 2014. 247 p. 
SARQUIS, Sarquis José Buiainain. Comércio internacional e crescimento econômico no Brasil. Brasília: Fundação Alexandre de Gusmão, 2011. 248 p.

SEMINÁRIO SOBRE A AMÉRICA DO SUL - A Organização do Espaço Sul-Americano: seu significado político e econômico. Organizadores: IEPES, IRBr, IPEA, BID. Brasília: 2002. 313 p.

SILVA, Karine de Souza; COSTA, Rogério Santos da. Organizações Internacionais de Integração Regional: União Européia, mercosul e UNASUL. Florianópolis: Ed da UFSC: Fundação Boiteux, 2013. $306 \mathrm{p}$.

SIMÕES, Antonio José Ferreira. Eu sou da América do Sul. Brasília: Fundação Alexandre de Gusmão, 2012. 120 p. $2011.116 \mathrm{p}$.

Integración: sueño y realidad en Sudamérica. Brasília: Fundação Alexandre de Gusmão,

SORJ, Bernardo; FAUSTO, Sergio. O papel do Brasil na América do Sul: estratégias e percepções mútuas. Plataforma Democrática. Working Paper $\mathrm{n}^{\mathrm{o}}$ 12, julho de 2011. Disponível em: $<$ http://www.plataformademocratica.org/Arquivos/Plataforma_Democratica_Working_Paper_12_Port ugues.pdf>. Acesso em: 13/05/2014

TRATADO CONSTITUTIVO DA UNASUL. Disponível em: $<$ http://www.planalto.gov.br/ccivil_03/_Ato2011-2014/2012/Decreto/D7667.htm> Acesso em: 18/08/2013.

TRATADO DE ASSUNÇÃO. Disponível <http://www.mercosur.int/innovaportal/file/3862/1/cmc_1991_tratado_es_asuncion.pdf> Acesso em: $18 / 08 / 2013$.

TRATADO DE MONTEVIDEO 1960. Disponível em: <http://www.parlamento.gub.uy/htmlstat/pl/tratados/trat12859.htm> Acesso em: 25/08/2013.

TRATADO DE MONTEVIDÉU $1980 . \quad$ Disponível em: <www.desenvolvimento.gov.br/arquivos/dwnl_1222694868.doc> Acesso em 15/08/2013.

UNASUL. Disponível em: <http://www.unasursg.org/> Acesso em 26/08/2013.

VEIGA, Pedro da Motta. RÍOS, Sandra P. O regionalismo pós-liberal, na América do Sul: origens, iniciativas e dilemas. Série Comércio internacional N. 82. Santiago de Chile: División de Comercio Internacional e Integración, CEPAL, 2007. Disponível em: <http://www.eclac.org/publicaciones/xml/5/30045/S82CI_L2776e_P_Oregionalismo_pos_liberal_Am erica_do_Sul.pdf> Acesso em 28/08/2013.

VIDIGAL, Carlos Eduardo. A integração Sul-Americana como um Projeto Brasileiro: de Uruguaiana às Malvinas. In: A América do Sul e a Integração Regional. Rio de Janeiro: Fundação Alexandre de Gusmão, 2011.

WORLD ECONOMIC FORUM. Global Risks 2014 Ninth Edition. Genebra. Disponível em: $<$ http://www3.weforum.org/docs/WEF_GlobalRisks_Report_2014.pdf> Acesso em: 01/01/2015. 